$5 B 732$

, H 4

\title{
BLACK ROT, LEAF SPOT AND CANKER OF POMACEOUS FRUITS
}

\section{A THESIS}

Presented to the Faculty of the Graduate School of CORNell University for the Degree of DOCTOR OF PHILOSOPHY

BY

LEXEMUEL RAY HESLER

Published as Cornell University Agricultural Experiment Station Bulletin 379 August 1916 



\section{BLACK ROT, LEAF SPOT AND CANKER OF POMACEOUS FRUITS}

\section{A THESIS}

Presented to the Faculty of the Graduate School of Cornell University for the Degree of DOCTOR OF PHILOSOPHY

BY

LEXEMUEL RAY HESLER

Published as Cornell University Agricultural Experiment Station Bulletin 379 August I9I6 
$S B 732$

. $\mathrm{H}_{6}$

In Exchango.

Comell Univ.

$\because \vdots$ 


\section{CONTENTS}

Host considerations . . . . . . . . . . . . . . . . . . . . . . . . . 53

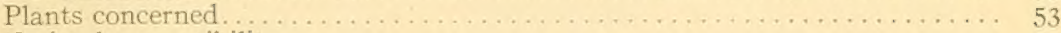

Varietal susceptibility . . . . . . . . . . . . . . . . . . . . . . 53

Of fruit to black rot........................... 53

Of foliage to leaf spot. . . . . . . . . . . . . . . . . . . . . . . . . 53

Of limbs to canker. . . . . . . . . . . . . . . . . . . . 53

The disease. . . . . . . . . . . . . . . . . . . . . . . . . . . . 54

Names. . . . . . . . . . . . . . . . . . . . . . . . . . . . 54

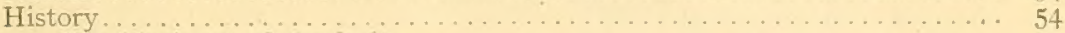

The black rot of the fruit . . . . . . . . . . . . . . . . . . . . 54

The leaf spot ........................................ 55

The canker form . ............................... 55

Geographical occurrence. .............................. 56

Economic importance . . . . . . . . . . . . . . . . . . . . . . . . . . ${ }_{5}^{8}$

General considerations................................. 58

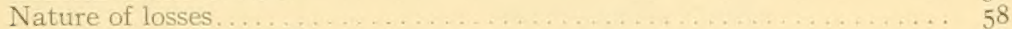

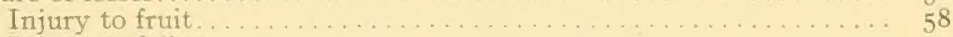

Injury to foliage . . . . . . . . . . . . . . . . . . . 59

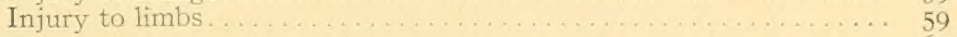

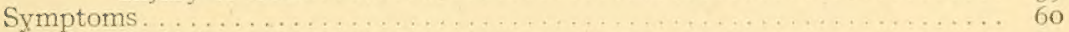

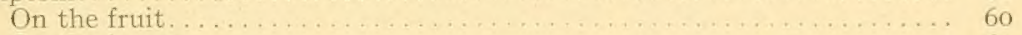

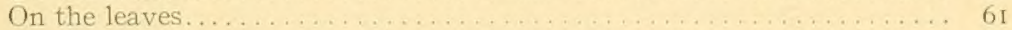

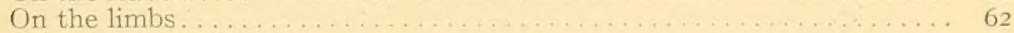

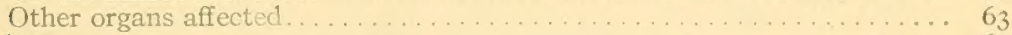

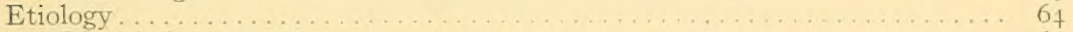

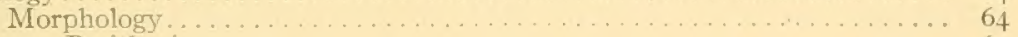

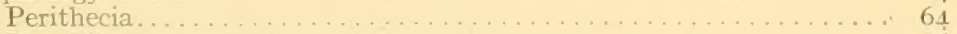

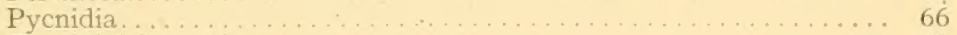

Pycnidial formaticn . . . . . . . . . . . . . . . . . . . 68

Pycnospores............................ $7^{1}$

Mycelium................................... 74

Sclerotia............................... 75

Chlamydospores.................................... 75

Microconidia . . . . . . . . . . . . . . . . . . . 76

Yeast forms. : . . . . . . . . . . . . . . $76 \ldots \ldots \ldots \ldots$

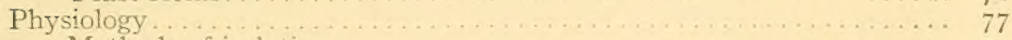

Methods of isolation. .......................... 77

Cultural characters - general . . . . . . . . . . . . . . . . . 77

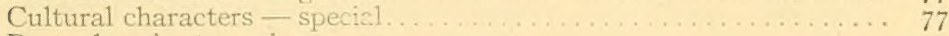

Protoplasmic streaming. ....................... 77

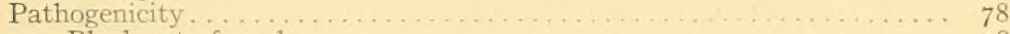

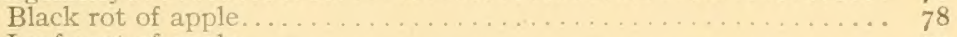

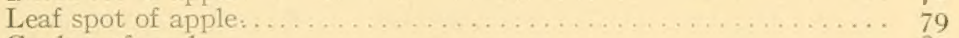

Canker of apple............................... 87

Cross-inoculations and host relationships.............. 95

Names and synonymy. . . . . . . . . . . . . . . . . . . . . 99

Life history studies.........................

Source of the inoculum . . . . . . . . . . . . . . . . .

Method of spore discharge . . . . . . . . . . . . . . . . . 103

Time of spore discharge......................

Agents of dissemination........................ 105

Infection courts............................. 105

Pycnospore germination . . . . . . . . . . . . . . . . . 107

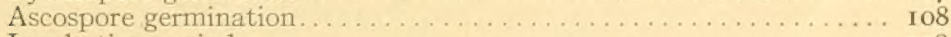

Incubation period $\ldots \ldots \ldots \ldots \ldots \ldots \ldots \ldots \ldots \ldots \ldots \ldots \ldots \ldots$ 
PAGE

Pathological histology. . . . . . . . . . . . . . . . . . . . 109

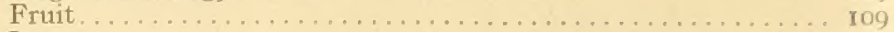

Leaves... . . . . . . . . . . . . . . . . . . . . . . . . . I Io

Bark. . . . . . . . . . . . . . . . . . . . . . .

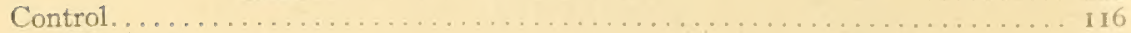

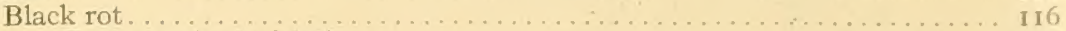

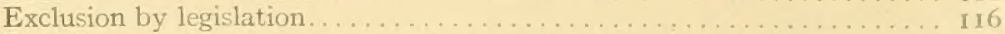

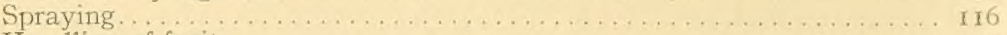

Handling of fruits. . . . . . . . . . . . . . . . . . . . . . . . . .

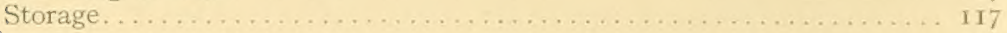

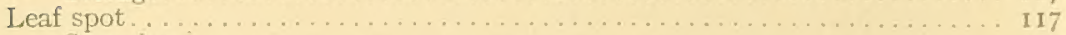

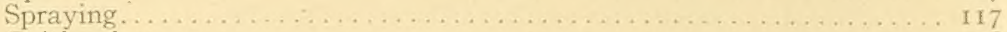

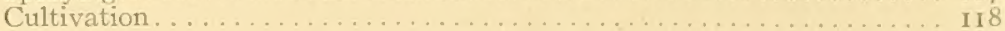

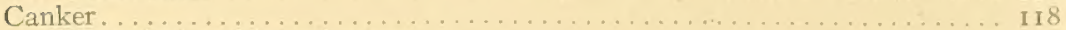

Historical and introductory . . . . . . . . . . . . . . . . . . .

Surgical methods. . . . . . . . . . . . . . . . . . . . . . . II9

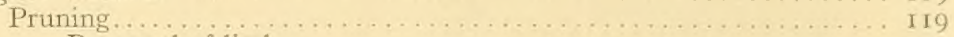

Removal of limbs...................... I I9

Removal of diseased bark. . . . . . . . . . . . . . . . . . 120

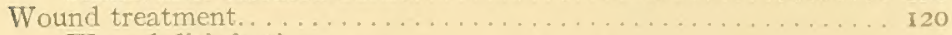

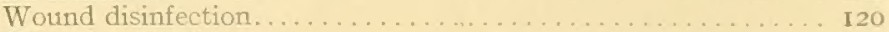

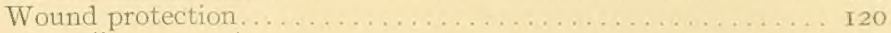

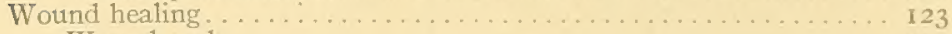

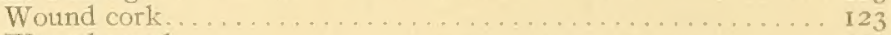

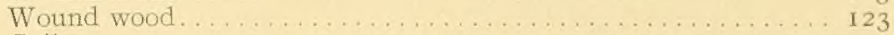

Callus. . . . . . . . . . . . . . . . . . . . . . 123

Spraying . . . . . . . . . . . . . . . . . . . . . . . . . 124

General considerations. . . . . . . . . . . . . . . . . . . . . . . . . 124

Orchard management. . . . . . . . . . . . . . . . . . . . . . . . 125

Resistant varieties. . . . . . . . . . . . . . . . . . . . . . . 125

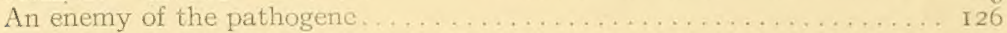

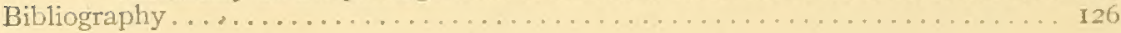




\title{
BLACK ROT, LEAF SPOT, AND CANKER OF POMACEOUS FRUITS
}

\author{
L. R. Hesler \\ HOST CONSIDERATIONS \\ PLANTS CONCERNED
}

The black rot, leaf spot, and canker of pomaceous fruits is primarily a disease of the apple, Pyrus Malus L. It affects other trees also, however, especially the pear (Pyrus communis L.), the quince (Cydonia vulgaris Pers.), and the crab (Pyrus coronaria L.), showing on these hosts symptoms similar to those on the apple. In addition the pathogene infests the dead parts of a great variety of other trees and shrubs, but in such cases there is usually no evidence that it has been the causal factor in the death of the tissues. In the State of New York, at least, this disease is of economic importance only on apple trees.

OF FRUIT TO BLACK ROT

VARIETAL \$USCEPTIBILITY

The summer varieties of apples are affected by black rot at the time of ripening, while winter varieties commonly suffer in storage. In Connecticut black rot is a most troublesome storage rot (Clinton, I9 I $5: 5)^{2}$ OF FOLIAGE TO LEAF SPOT

Brooks and DeMeritt (I912:183), in New Hampshire, note striking differences in the varietal resistance of apple seedlings to leaf spot. In Virginia, Ben Davis and Black Twig are more severely attacked than are other varieties (Reed, Cooley, and Rogers, I9I2:5). Salmon (I907), writing from England, states that among the varieties most affected there are Peasgood, Nonsuch, Cox's Orange, and others. The writer has noted that Chenango, Baldwin, Rhode Island, and Twenty Ounce show spotted foliage more commonly in New York than do other varieties.

\section{OF LIMBS TO CANKER}

Varieties of apples exhibit a marked difference in susceptibility to the disease, and this variation is not the same with respect to the different parts affected. In western New York Twenty Ounce is the variety most severely affected by the canker. This variety is rarely found unaffected by canker, even in orchards that are managed according to improved methods. Neglected trees of the Twenty Ounce variety are often killed.

1 Also published as Cornell University Agricultural Experiment Station Bulletin 379.

2 Dates in parenthesis refer to bibliography, page I26. 
Paddock ( 1899 b: $18 \mathrm{r}$ ) says that certain growers in New York State have noted that Twenty Ounce is most likely to be attacked. He lists other varieties in order of their susceptibility, as follows: Baldwin, Wagener, Rhode Island, Tompkins King. Regarding the Esopus, Paddock ( $1899 \mathrm{~b}: 180$ ) says that this variety has apparently run out because of this disease. In Ontario, Ben Davis, Northern Spy, and other varieties are severely injured by the disease (McCready, roro).

\section{THE DISEASE}

\section{NAMES}

The disease on the fruit is called black rot, ring rot, blossom-end rot, and brown rot. The first name is descriptive and definite, and seems desirable.

Lesions on the foliage are termed leaf spot, brown spot, and frog-eye.

The names apple canker, black rot canker; and New York apple tree canker, are most commonly applied to the disease when it occurs on the bark. The term apple canker needs some qualification, since many kinds of cankers occur on the apple. It was under such an exigency that Paddock ( 1899 b:180, footnote) first used the name New York apple tree canker. The writer prefers to use this name regardless of its length, not alone because of priority, but also because of general usage.

\section{HISTORY}

THE BLACK ROT OF THE FRUIT

The disease on the fruit was observed by Peck (1879:20) in Schoharie County, New York, and he quotes the remark of stagecoach passengers that they "never before knew of apples rotting on the tree." Arthur (1885) records black rot of quince fruit at Geneva, New York, and notes the importance and infectious nature of the disease. Scribner ( 1890 ) notes the disease in New Jersey and describes the symptoms and causal nature. The same year Baccarini ( 1890 ), in Italy, observed the rotting of otherwise sound apples, pears, and peaches, the decay occurring in a storeroom of fruit gathered when ripe; this was a new appearance of the disease in that country. Two years later Halsted ( 1892 ) discussed the black rot of quince in New Jersey. Sturgis ( $1893, a$ and b) notes the disease on quinces in Connecticut in August, 1892, and later (1894) confirms the work of Halsted. Kinney ( $1895 \mathrm{c}$ ) figures and describes the disease in Rhode Island. In the same year it became an object of control measures in Kentucky (Garman, I895). Black rot of apple is reported by Burrill and Blair (IgOI) in Illinois; they give a careful description of the disease and distinguish it from other apple rots. The following year Clinton (1902), writing from the same station, remarks that the disease on 
apples had attracted attention for several years. and that it was known to have occurred in Illinois at least as early as 1879 . The disease as a storage rot was studied by Lamson ( $\mathrm{IgO}_{2}$ ) in New Hampshire the same year. Faurot ( 1912 ) describes the disease in Missouri.

W.A. Orton (1904, I905, I906, I907) publishes records of the black rot of pome fruits, the reports having come to him chiefly from the Middle West. In 1905 the black rot of quince and pear was especially injurious in Ohio. Evans (I9I0) called the attention of the apple growers of South Africa to the disease, which had just been found on apples at Grahamstown and also in a consignment of apples from Sidney, Australia. He urged the importance of excluding the disease from the Transvaal. Recent studies on black rot have been reported by Wolf (I9I3) in Alabama.

THE LEAF SPOT

The earliest record which the writer has found concerning the leaf spot is that by Alwood ( 1892 ), who reports brown spot of apple foliage in Virginia. He had noticed it for several years but states that it was not serious until I89 I, when an outbreak occurred over the State. Kinney ( 1895 b) describes the disease in Rhode Island on apple and pear leaves, and says that it was very common in that State in 1895 . Stewart ( 1896 ) reports having found the disease on Long. Island in May, I895; he notes that it had been observed in 1894 at Westbury, Long Island, by Professor Beach. Lamson (I899) lists the disease from New Hampshire and reports it as having done serious damage in some cases. Corbett (I900) reports " brown spot," or " frog-eye," as common throughout the southern and eastern counties of West Virginia, and as being more injurious than either blight or scab. Stewart and Eustace (1902) studied the cause and control of leaf spot in the eastern United States. The same year Clinton (IgO2) notes the severity of the disease in Illinois, and later (Clinton, I904) he reports its common occurrence in Connecticut. Stone and Smith ( $\mathrm{r}_{93}$ ) record it as one of the most noticeable diseases of the season of 1902 in Massachusetts. Scott and Quaintance (1907) report the spotting of apple foliage in the Ozark region, and in the following year there appeared a more extensive work on the leaf spot problem by Scott and Rorer (Igo8). Work on the leaf spot was begun in New Hampshire in 1908 by $\mathrm{I}$. M. Lewis (1908); this investigation was carried further by Brooks and DeMeritt (1912), who report it in full. Recent work on the leaf spot form of this disease has been published in Virginia by Crabill ( 19 I $_{5}$ ).

THE CANKER FORM

According to Paddock ( $1899 \mathrm{~b}: \mathrm{I} 80$ ), orchardists have been familiar with this canker disease for years. Attention was first called to the 
injury by Waite ( $1898 \mathrm{a}$ ), in a paper read at the meeting of the Western New York Horticultural Society in 1898 . In the spring of 1898 , Paddock ( 1898 , a and b, and 1899 a) began investigations which extended through two seasons. He records having noticed the disease as early as 1891, and says that it became important about 1895 . In 1897 , according to Paddock (I899 b: 192), considerable "twig blight" was found at Odessa, New York.

Mangin (IgoI) reports the disease in France on branches of apples, describing its symptoms in order, as he says, to put horticulturists on guard against invasion of the country by the pathogene. The same year Chester (I90I, a and b), in Delaware, observed what he believed to be the same disease on apples and pears. His attention had been called to the canker on the latter host in the spring of I900, near Smyrna. His illustrations suggest the possibility that the disease was the superficial bark canker of Edgerton (Igo8). A few years later Lochhead (I905) described the disease in Canada. Clinton ( 1907 ), writing from Connecticut, states that his attention was called to a peculiar disease of apple limbs in the spring of 1906 .

Another record of the disease which has appeared from France is that by Griffon and Maublanc (I9I0). They note very serious injury to pears in that country, and assert that at the national school of agriculture the disease was first known in I908. A study of the disease was taken up in Canada by Bethune (I909). He reports a great amount of damage from cankers in the region east of Toronto. The following year a synopsis of the investigations in the province of Ontario was published by McCready (I9ro). A point of interest noted in this paper is that the great freeze of $1903^{-1904}$ in Prince Edward County marked the beginning of the canker epiphytotic there. The disease has received further attention in France by Arnaud (I II2), who lists it as occurring on a number of different plants.

\section{GEOGRAPHICAL OCCURRENCE}

The disease has a very general distribution throughout the temperate regions of the globe. Heretofore it has been regarded as a disease peculiar to eastern and middle western America, but it is now apparent that its limit is no longer to be so regarded. It has been found in Canada, particularly in Ontario (Bethune, I909), Quebec (Lochhead, I905 and I909), and Nova Scotia (Plant Pathology Herb., Cornell University Exsicc. no. 2657 , and Gussow, letter to the writer). It occurs in Europe from Italy to England, according to the observations of Shear (I9I3:8I-82). From England Berkeley ( 1836 ) reports it on apple fruit, while Salmon (1907) found it on apple foliage. It is unknown in Norway (Schöyen, letter to the writer), while both Ravn and Lind (letters) state that it 
is not present in Demmarl. From Russia the discase has been reported by Potebnia (I0)- ant Iuro). Jaczemsly lletter to the writer) states that the black rot and canker forms oneur in the provinces of Kharkof and Tehernignf, and in the Transcancasian and Turliestan regrions. Potelnia (letter) hats collected all the forms in Furst; neat the city of Fatei, and states it as lis minion that the clisease occurs generally throughout Russia. Bulvili (u)ou) remets it from Austria-Hungary. It probably occurs in Switzerland. (jommany, and I Isllanel, acconding to the general

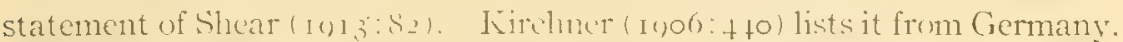
It may not be prevalent there, hewerer, for Jollmung (letter) says the disease is not well known in Silchsen. Its occumence in France is reported by Arnaud ( 19 I 2 ) and others. The lilack rot form has been collected in the vicinity of Brussels, Bclunum, hy Bummer and Rousceat ( ISS5). Some years ago it was intrutuced into (a1) C"ulony from New South Wales (Evans, I910:62, footnote).

So far as the writur has ben alle to ascertain, the discase is widely

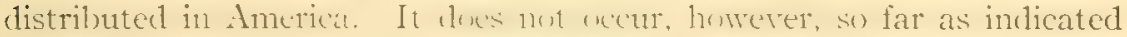
by results from a circulat letter sont to the plant patholowists of the state agricultural experinest stat ioms, in the follewing States: Arizona, Colorado. Florida, Idaho, Loulisima, Memiana. Nevata, North Dakota, South

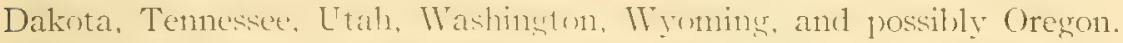
The canker form is commonest in the East, especially in Nerv York, while fruit rot seems to ment more frepuently in the New England and Midelle Atlantic sections, althum Wilson (1013) reports its occurrence throughout Nonth America cast of the Rocky MIonntains. In the Middle Western States, particularly ()lin and Indiana, the pear and quince, as well as the apple, appear to have suffered considerably. Quaintance and Scott ( 1012 ) state that the leaf sput wecurs in all sections east of the Rocky Mnuntains where the apple is stown. In another publication Scott (rotz) asserts that it is fommd in all humid sections of America.

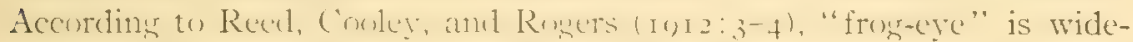
spread in Tirginia. ()ther Siates in which the discase uecurs are Arkansas, Connecticut, Illinois, Maryand, Massachusctts, Missouri, Nebraska, New Hampshire, New Jorts (particulaty Lomer Island), Rhode Island, and West Virginia (Scott and Rorer, I $908: 48-49$ ).

Probably no apple discasc excert applescal, is commoner in New York State than the one here concilererl. 'Throushout western New York the canker fomm is very provedent. From roplies to a circular letter sent

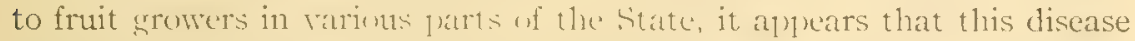
is more or less common and seritus in all sections, except possibly in the central eastern part. The fruit and fuliase rarely suffer apureciably in the State, although black rot and leaf spen are not infreouently found. 


\section{ECONOMIC IMPORTANCE}

\section{GENERAL CONSIDERATIONS}

The nature of the losses caused by this disease makes very difficult the possibility of an estimate concerning them. So far as the writer has found, no reliable datia are at hand in regard to this point. The combined injuries produced by the canlser, the black rot, and the leaf spot are doulthess rreater than is commonly supposed. It is undoubtedly true that the New Tork apple tree canker is often confused with other cankers by some growers, thus increasing the difficulty of obtaining reliable estimates on the destructiveness of this disease.

It is generally considered that canker is one of the commonest and most troublesume discases of the apple, although its destructiveness is not uniform in different parts of the country. According to Shear ( In I3: $8 \mathrm{I}-82$ ), the black rot disease of apple is found in Europe from Italy to England; yet he states that noticeable injury from the disease in orchards has never been reported. On the other hand, Griffon and Maublane (1910:30S) state that in France the injury may be very serious. In contrast to the general situation in Euroje, it may be noted that the damage done by this disease in America is great.

\section{NATURE OF LOSSES}

INJURY TO FRUIT. Whenever pome fruits are attacked they are rendered worthless so far as their market value is concerned. The extent of injury may be small while the fruit still hangs on the tree, but ultimately in storage complete destruction is likely to result. Brooks (I909) states that in New Hampshire the black rot is very common and does considerable damage in cellar storage. Burrill and Blair (I.90I:2) report "xreat loss at times" in Illinois, and Clinton (1902), in the same State. compares the importance of bitter rot and black rot of apple. The latter he regards as likely to occur in every orchard to some extent. In Kentucky, black rot of apples is regarded as the commonest of fruit rots, according to Garman (ISo5:I2j). Stone (letter to the writer) estimates that in Massachusetts from eighty to ninety per cent of fruit rots is black rot. Evans ( I I IO) rejorts a case in which rotting and mummified pome fruits appeared in a shipment to Cape Colony, and states in this regard:

During the past three muthe four hundred and ninety-eight cases of apples and pears in this condition from (ape (c)lony have been detained, and in order to safeguard the interests of Transvial fruit growers, the Government, under Government Notice No. 500, of tsth June, Igos, have warned importers of fruit that all consignments of pomaceous fruits found infected with this fungus to the extent of one per cent and upwards will he destroyed upon arrival in this Colsty or returned to the consignor.

There is no reason tis supure that this num ${ }^{1}$ er by any means represents the total amount of discaserl fruit that has reached the Transvaal, to say nothing of the other parts of South Africa. 
INJURY TO FOLIAGE. The damage to foliage depends on the extent of

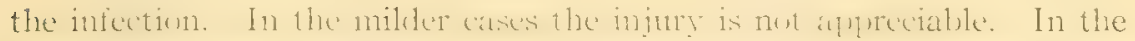

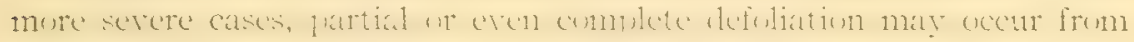

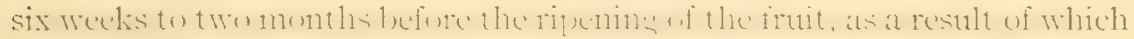

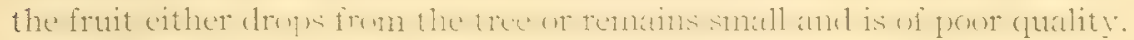

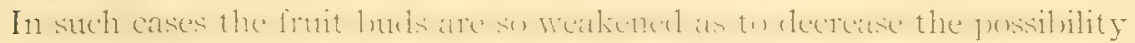

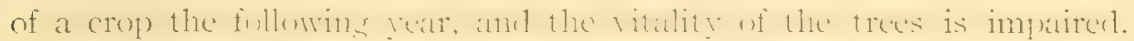

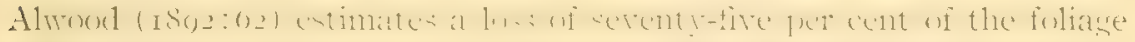

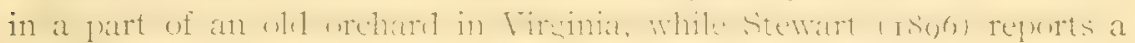

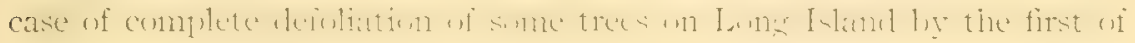
July. It is interesting to note, for comparison, that in Igoo, in West

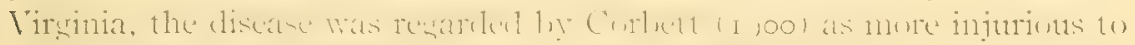

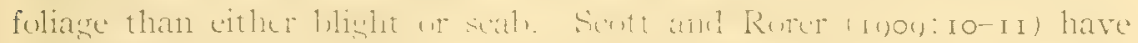
observed a case in which. at the heliche the ratherene canding this

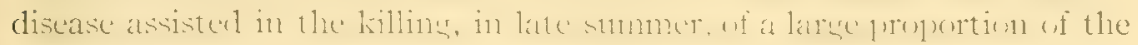
fruit buds of the apple. They state that on Winesaps it would seem

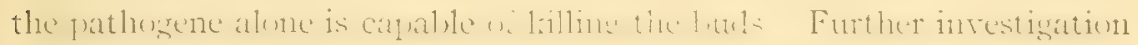
is deemed desirable by these writers.

INJURY TO LIMBS. As a rule the canker is confined to the orchard,

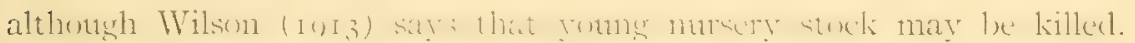

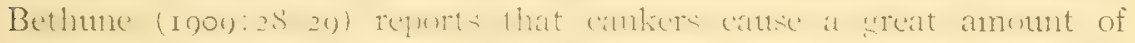

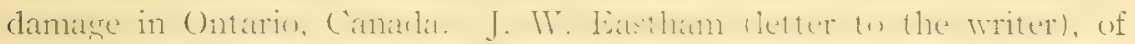

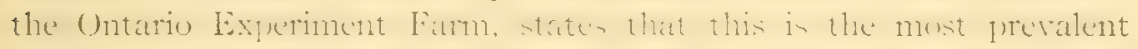

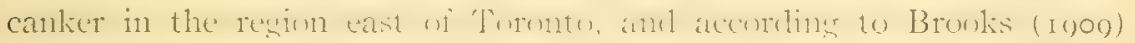

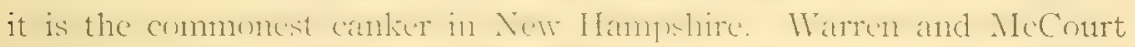

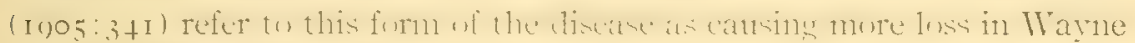

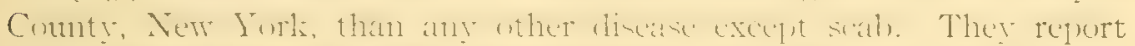

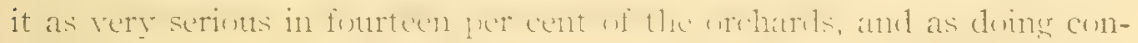

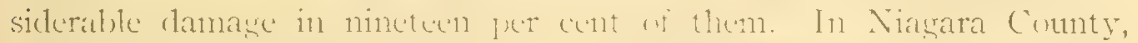

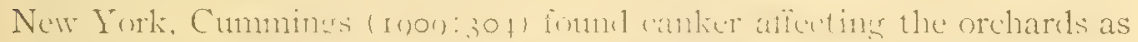

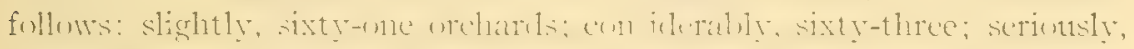

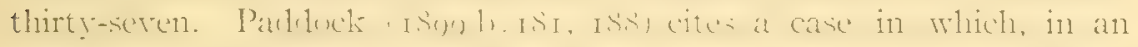

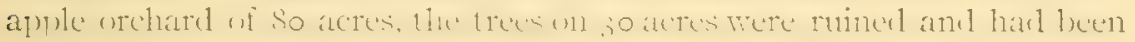
taken out; the trese on the nematining so arewes were then of little values.

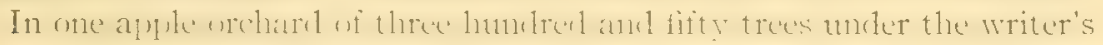

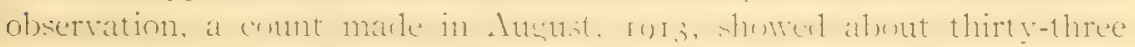

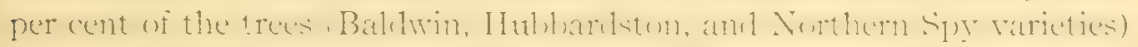

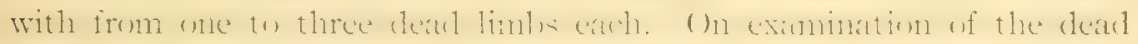

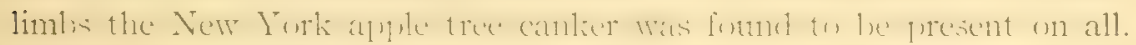

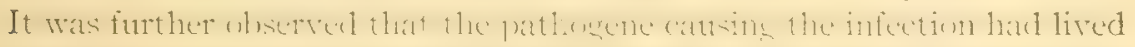

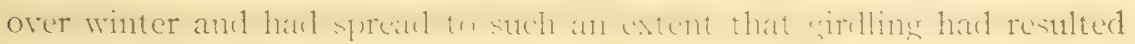
and the foliage hatel turned fellow and wilterl. The iruit on such limbs 
som shriveled and was lost. $\Lambda$ careful contut surwed that approximately ten or twelve barrels of fruit were rendered worthless. 'The loss here

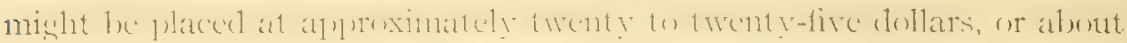
seven cents a tree. According to the United States Census for IgIo,

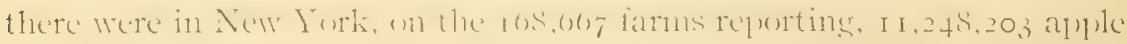

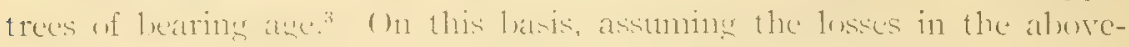

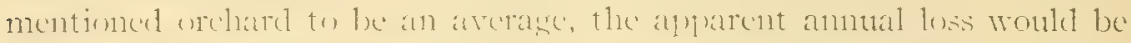
alune thete-fourthe of a million dollars for a single seasen in New York State. Many cases ran be eiterl in which the infection by New Tork apple

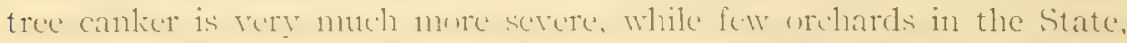

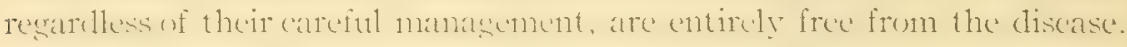

Epiphytoties of this disease, such as have recently beon experienced in the case of the chestunt hlicht, are of rare or unknown occurrence. It is characteristice of the disease to tate a constant toll year after year, like the

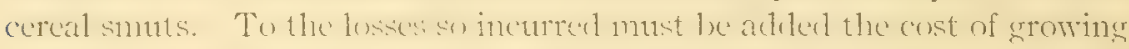

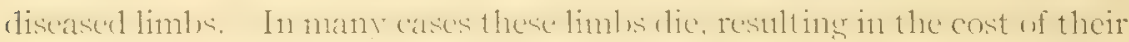

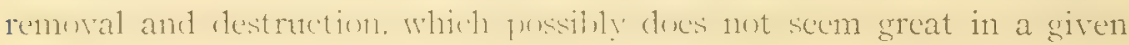
year but is not negligible in the aggregate.

\section{SYMPTOMS}

\section{ON THE FRUIT}

The discase on the frut is fumarily a ripe rot, but it may appear several weeks before mat urity of the lruit. It may lexin anywhe on the surface or at the liksime enul. Frequently the lesinns are contered alunt an injury such as that caused by insects or hail (Plate vII, I).

Usually there is only one spot on a fruit. The skin at first becomes

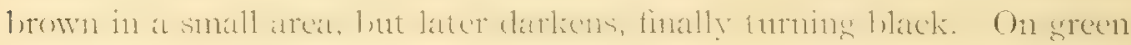

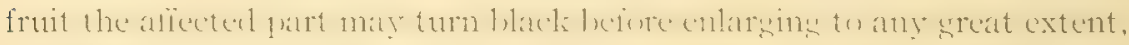
whereas on frut that is ripe or rigening, the whole may be involved betore

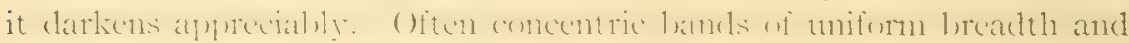

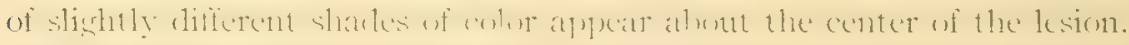

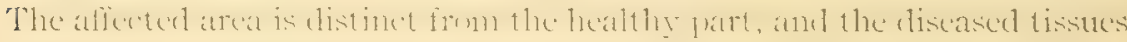

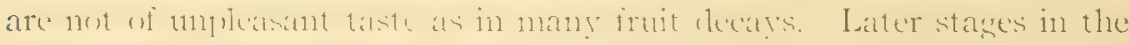

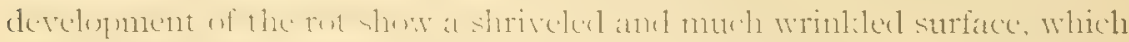

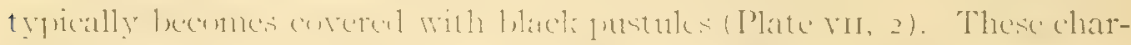

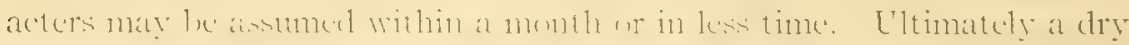
mummy is produced, which may hang to the tree for a year or more.

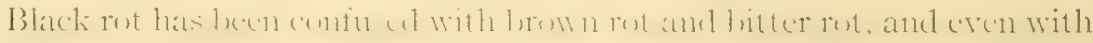

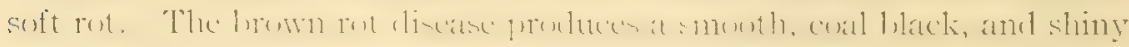

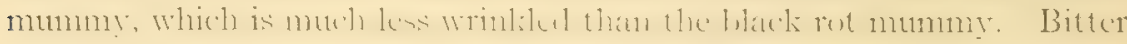

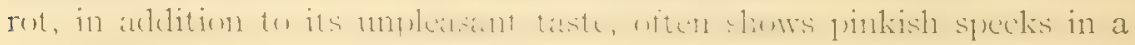




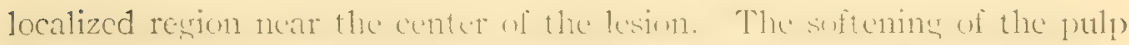

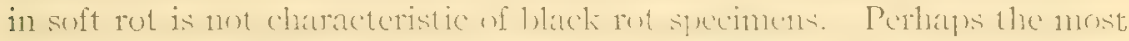

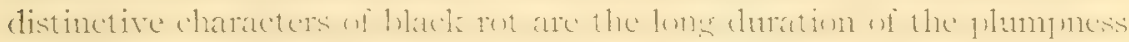

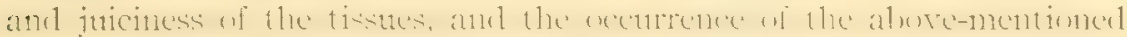

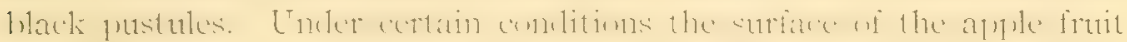
also becomes studded with white tufts; but these are not commonly found and are not to be regarded as a diagnostic symptom.

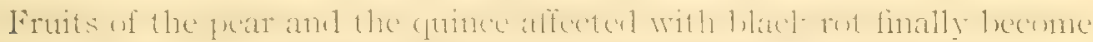

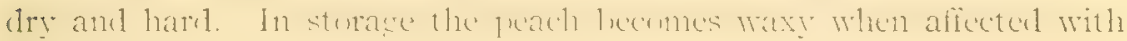
the disease, according to Baccarini (I890:67).

\section{ON THE LEAVES}

The foliage of the apple is more freptently atlacked than that w the

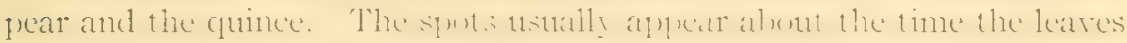

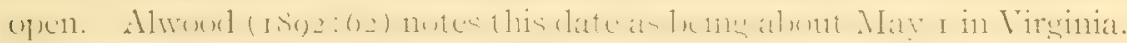

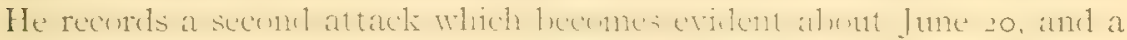

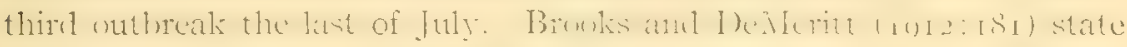

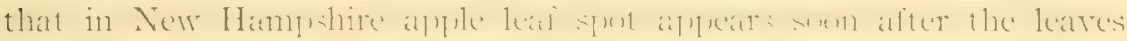

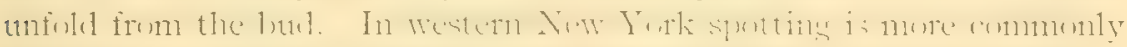

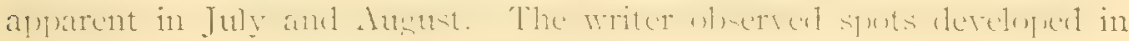
September, I9ז3, at Byron, New York.

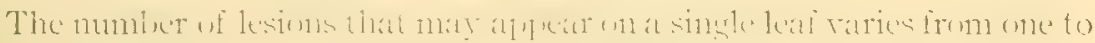

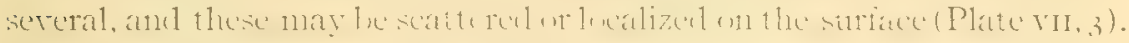

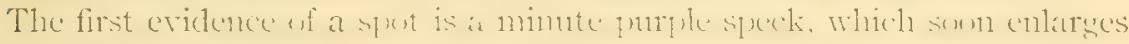

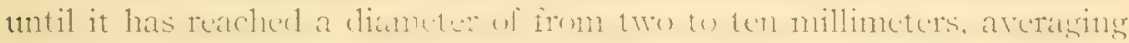
about four millinetert. The purplish orlut is mantained for a considerable time, during whed lhe matren is somewhat indefinde. Later the

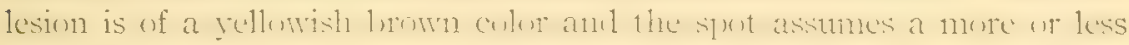

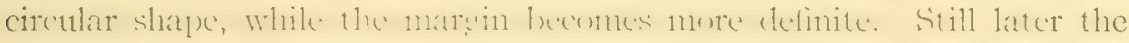

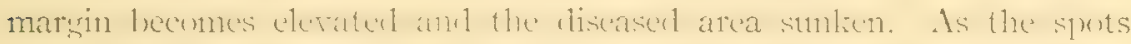

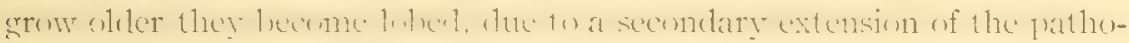

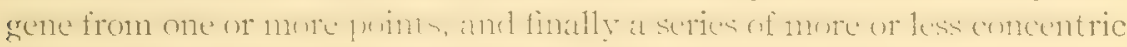

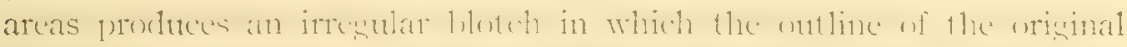

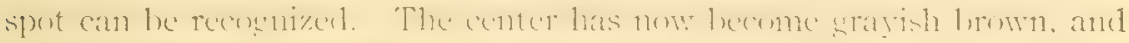

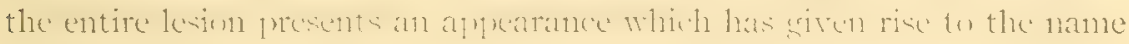
frog-eye.

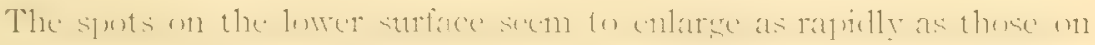
the upper, but they are not so conspicuous. Sometimes the center of the spot on the lower surface is grayish brown. The whole diseased area may, however, merely appear dark and indefinite.

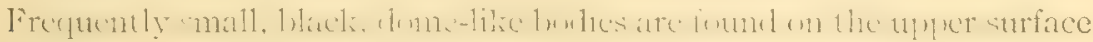

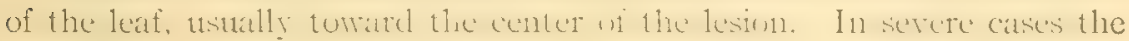


leaves turn yellow and fall from the tree. According to Brooks and

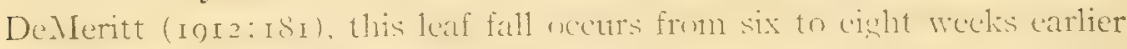

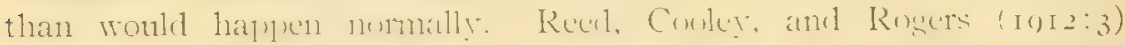
maintain that defoliation maty ocur (arly (mough for a new (rop) of leaves to be put forth the same seatom. Trees roblued of their folliage from vear to rear must eventually fecome steatly relued in vitality and finally succumb to a premature death.

Bordeaux injury is snmetimes very similat to frow-ere leaf spot; Bronks and Dedferitt (1012: Ir)o state that this is especially true if rains follow

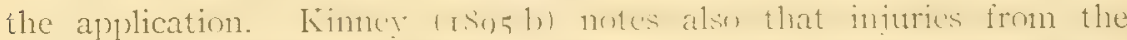
leaf miner (Tischiria malifolidh Clemens) are sometinnes mistaken for leaf spot.

\section{ON THE LIMBS}

In western New York, yomes sputs may be fonmel on the hark at any

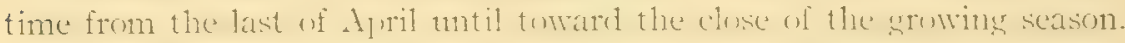

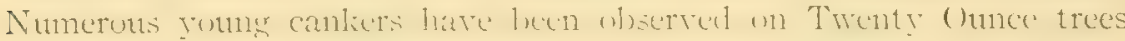
in Monroe Conuty orcharts during the month of Angret. It is the

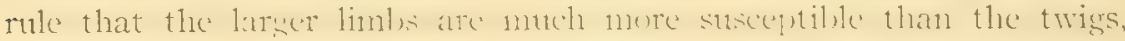
and the trunks show connparatively fow lesions. The canliers on the

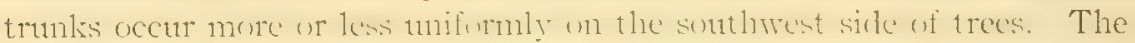

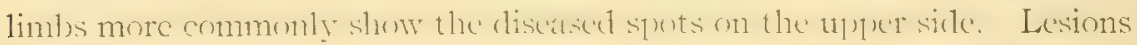
are very often fonnd atkut the hase of a smail limb or alont a wound in the bark.

In the carlice stages of the formation of a canker, the hark is slightly sunken (Plates vin, and Ix, f) and remlish bremen in color. The discased

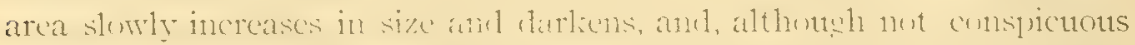

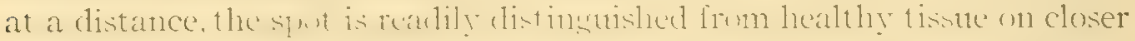

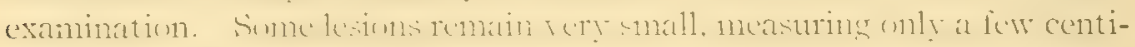

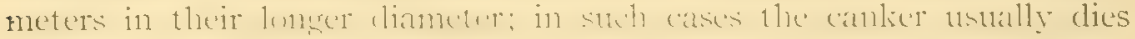
out at the end of the year. Where the injury is larger, the diseased

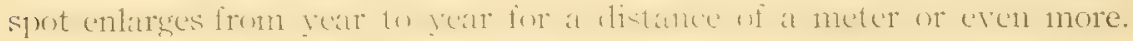

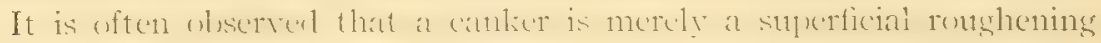

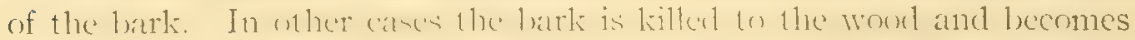
conspicuously cracked (Plate $\mathrm{x}$ ).

The discoloned area mate extend were a comsilerable surface; or, regardless of its size, a crevice maty alpear at the marsin, limiting temporarily at least, the extent of the lesion. Further spreat of the patherene results in the formation of a fomminent spot. which som forms a second line

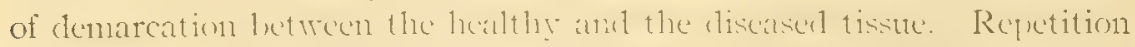
of this process from one on more fuints at the maruin accurs, thus producins a lobert appearance (Plate $x, 2$ ); or the spreading may arise from 
all points about the first maryinal crack, so that a series of concentric crevices is developed, as described for frog-eye of the leaves. The bark remains closely appressed to the wood for at least a year; later the dead bark cracks and falls away, exposing the rood and a callus around the margin of the wound (Plate $\mathrm{x}, 3$ ).

Cankers that begin to form early in the season show numerous fruiting pustules of the pathogene scattered over the central area of the spot. These may not become evident, however, until the second season.

Large limbs are rarely girdled the first year; the grirdling comes alont by the enlargement of the canker the following season. Complete encircling restilts in the death of the parts abore the canlecr, as evidenced by the yellowing and dropjing of the leaves ( Plate .rir, 1) and the shriveling of bark and fruit. It is not uncommon in such cases to find the fruit clinging to the twigs for a year or more.

Clinton ( Ino7) describes a peculiar ty'e of lesion on apple limbs. He says, in part:

Another and more peculiar feature of the troulste was the enlargement of the limbs into somewhat fusiform swellings, as shown in the illustration. In some eases several of the swellings followed one another on the same limb. These ctrlaryements generally showed a greater swelling on one sile than on the uffumite, and often the bath was split down the mure swollen side. Crose and longitudinal sections showed that the swellings were apparently the result of severe cold, which hat injuret the limb is unevenly along the branch, as shown by the blackened wood on the injured portion.

Delacroix (1903a: 135) notes a thickening at the base of some cankers. This he finds to be a sort of cushion developer in a transverse direction in the healthy bark. The writer has occasionally obscrved cankers showing hypertrophy at the upper and lower ends of the diseased part (Plate $x, 4)$.

It is to be noted that on quince twirs the cankers are often very indefinite. A rare specimen is shown in Plate $x, 5$. The nomal color of the bark is not distinctly lighter than that of the discased part, so that on this host the disease doubtless passes unnoticed in many cases.

\section{OTHER ORGANS AFFECTED}

A unique case in Virginia of fall blossoming of the apple following the canker has been described by Reed ( I908). 'This author found normal blossoms on an apple tree in the urchards of the Virginia Experiment Station on October 5. The cankers on the limbs had caused the death of more than half the top of the tree, and many branches, sererely affected, had been able to make a very small amount of growth during the season. Reed says: "It was on such branches as these that irnit buds were found open on the above named date. Examination of the blossoms showed that they were normal as regards parts, color, and internal relationships. 
I am informed by Professor H. L. Price of the Department of Horticulture of this Experiment Station that this fill hlusiming is not uncommon on trees which are badly affected by the black rot fungus."

\section{ETIOLOGY}

The pathogene here concerned is the fungus Ply'salospora Cydoniae Arnaud.

\section{MORPHOLOGY}

PERITHECIA. The perithecia have becn found by the writer on the twigs of apple (Pyrus malus L.) and of witch-hazel (Hamamclis virginiana L.), and have been (leseribel hy him in another publication

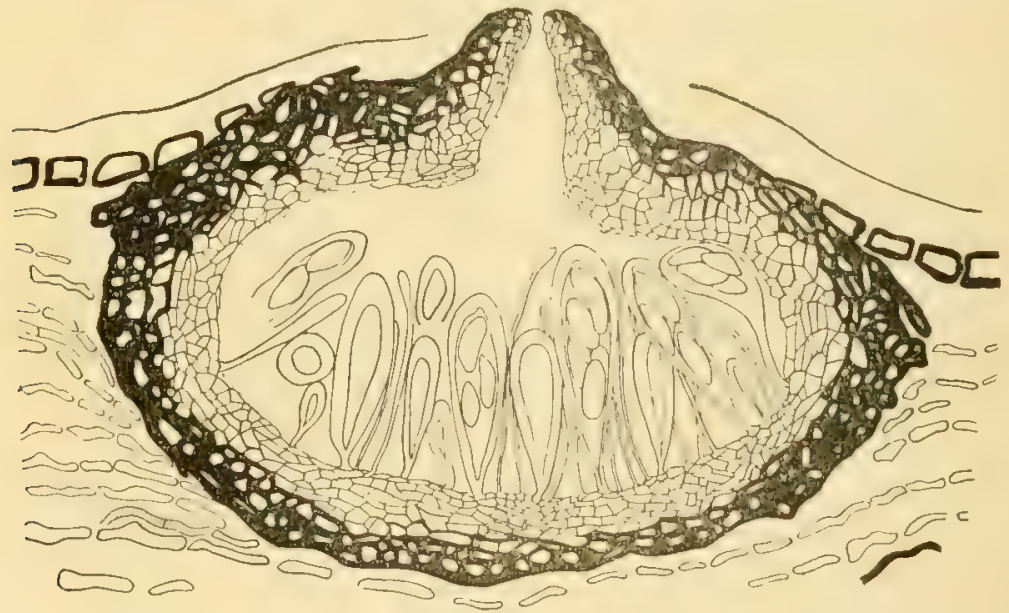

FIG, I 8. PERITHECIUM OF PHYSAlOSPORA CYDONIAE

Camera lucida drawing of a meduan longisection ot a typical perithecium

(Hesler, I9r3:293). Recently the writer has found the ascosenous form on twigs of white oak (Quercus alba L.).

The perithecia are ustally scattered, standing separate from one another. Sometimes, however, from two to four fruit lxdies are joined together, but no stroma has ever feen observen. 'They ate buried in the cortical tissues, protruling at maturity hy a short, papillate ostiole. Their form is globose to subgrobose, measuring from 1 so to $32+\mu$ in the vertical diameter by 300 to $400 \mu$ in the horizontal dismeter, averaging about 225 by $325 \mu$.

A typical perithecimm is shenen in finure is. The watl is elifferentiated into two layers. The thickines of the mute layer varies slightly with the sides and base of the perithecium, and the psemdo-cells are thick- 

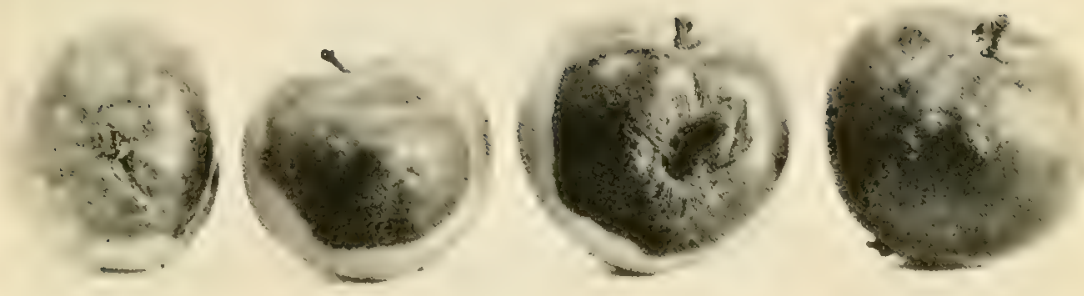

1
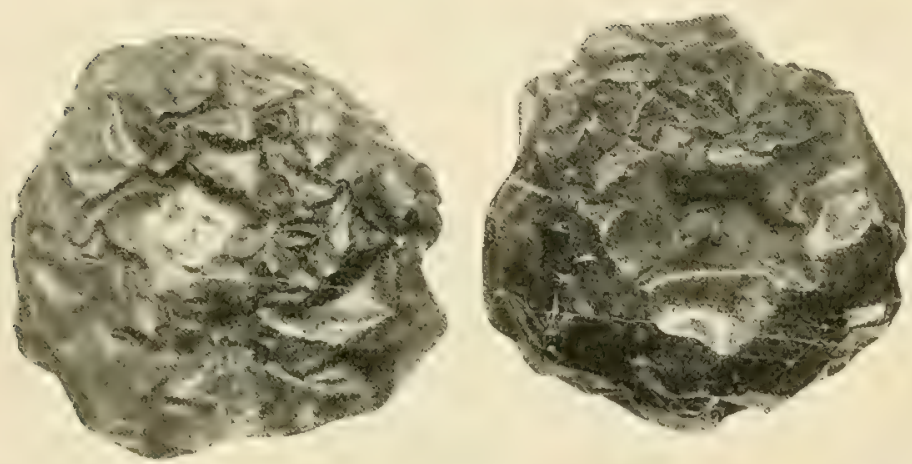

2

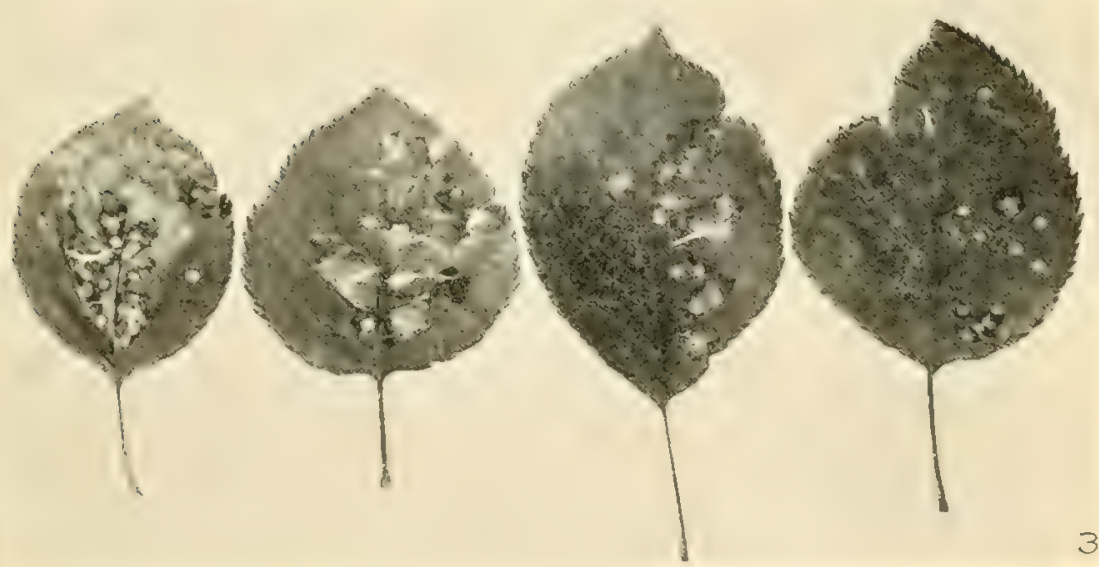

SYMPTOMS OF THE DISEASE ON FRUIT AND FOLIAGE

r. Types of infection on apples, early stages

2. Apples reduced to mummies as a result of the disease

2. Types of infection on apple leaves as commonly found in New York State 


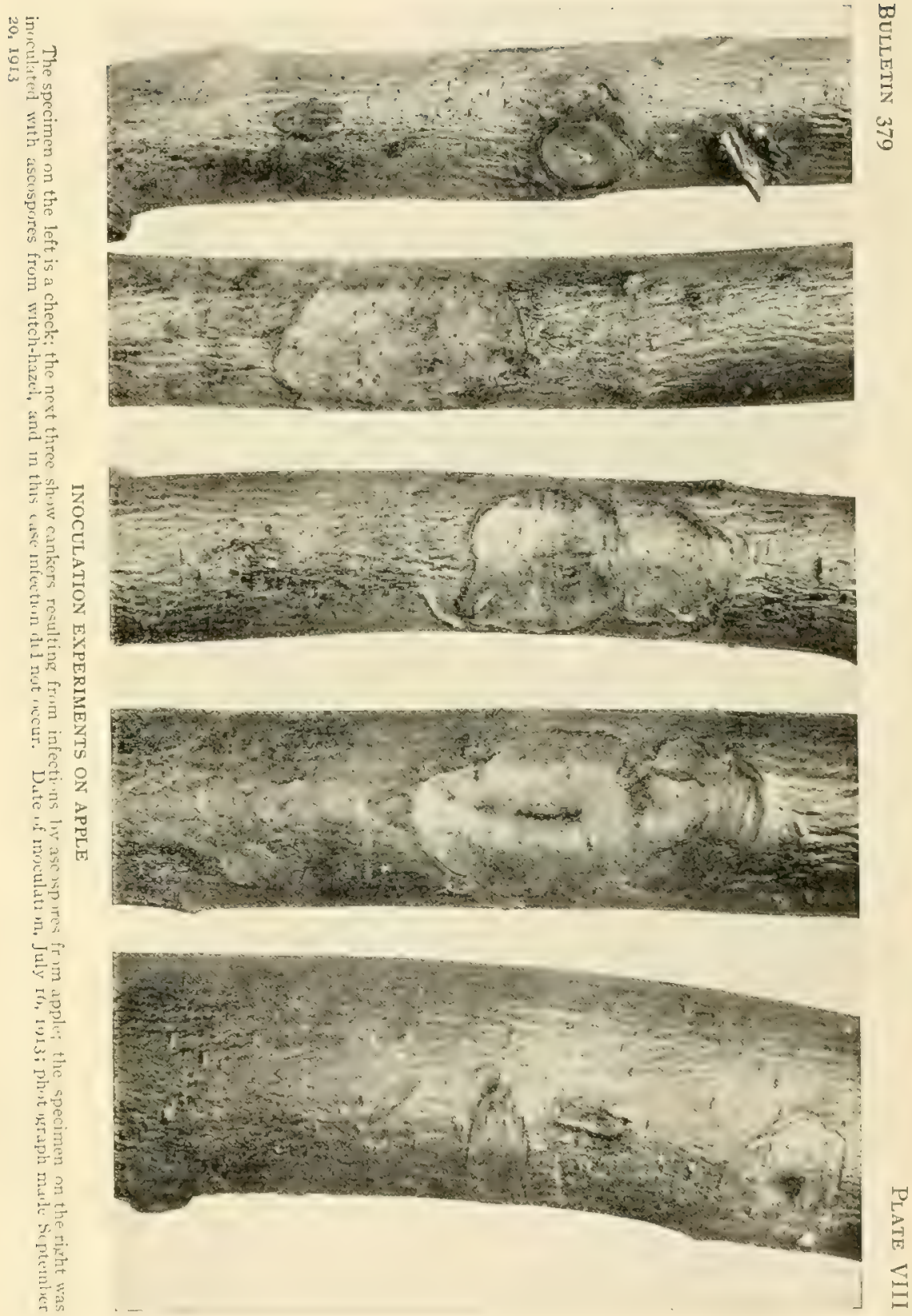



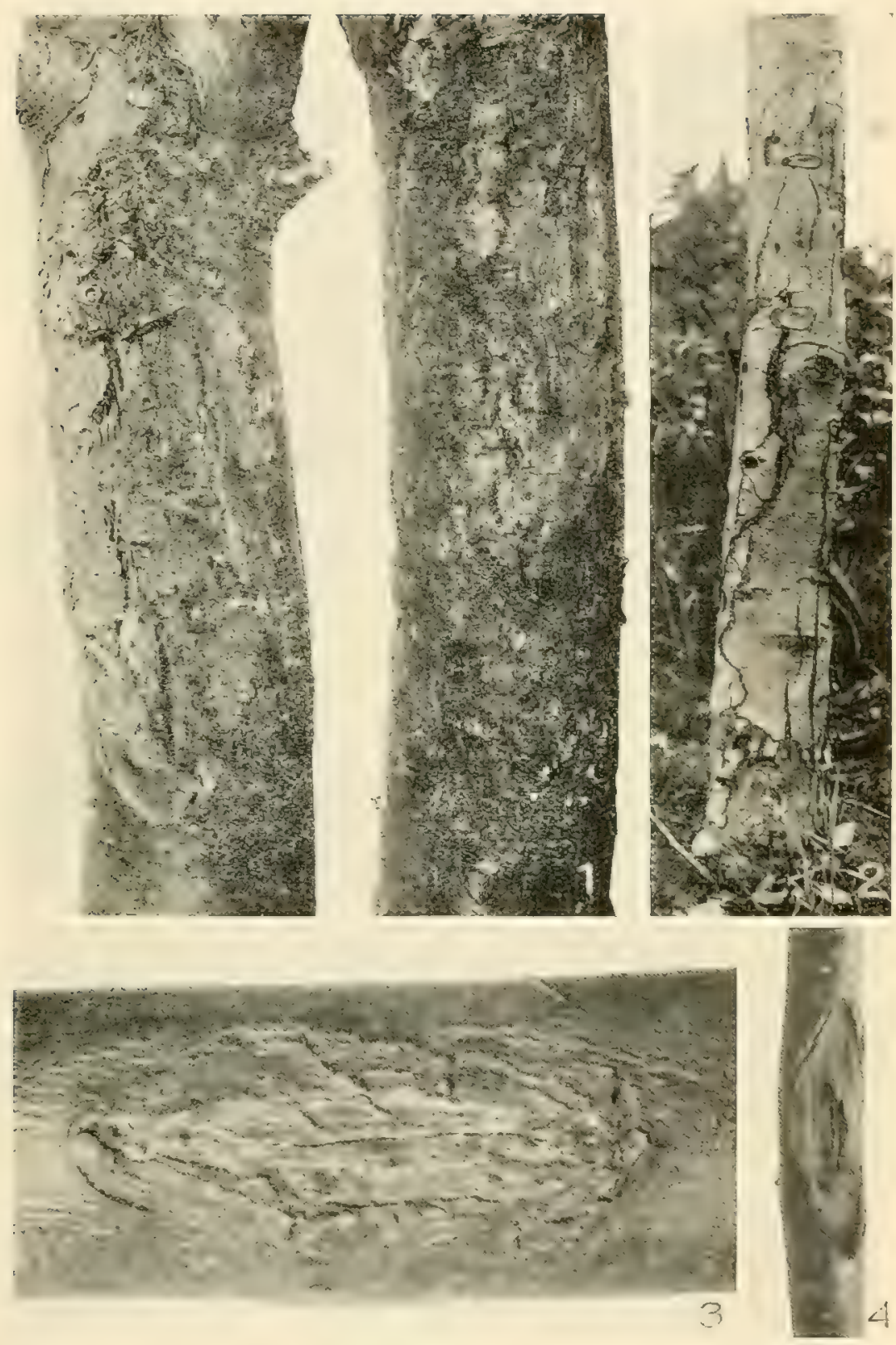

NATURAL CANKERS AND CANTERS FRODUCED BY ARTIFICIAL INOCULATION WVITII IHYSALOSPOEA CYDONIAF

r. Natural infection on the left; ertificial infection on the right. The latter inoculated on July I, 1013. with a strain from Twenty Ounce apple bark. Photograph made September 30, 1013

2. Canker on trunk of mature pear iree. Inoculation made July I8, I9lo, photograph made September I, I9I I

3. The result of inoculation by use of pycnospores from apple leaves. The healing process has occluded the wound before the pathogene could produce a large canker. Inoculation made July $\mathbf{I}$. 1012. photograph made September 20.1013

4. Canker on Baldwin twig produced artificially, using ascospores from apple. Inoculation made July 25, I914, photograph marle December 10, 1014 


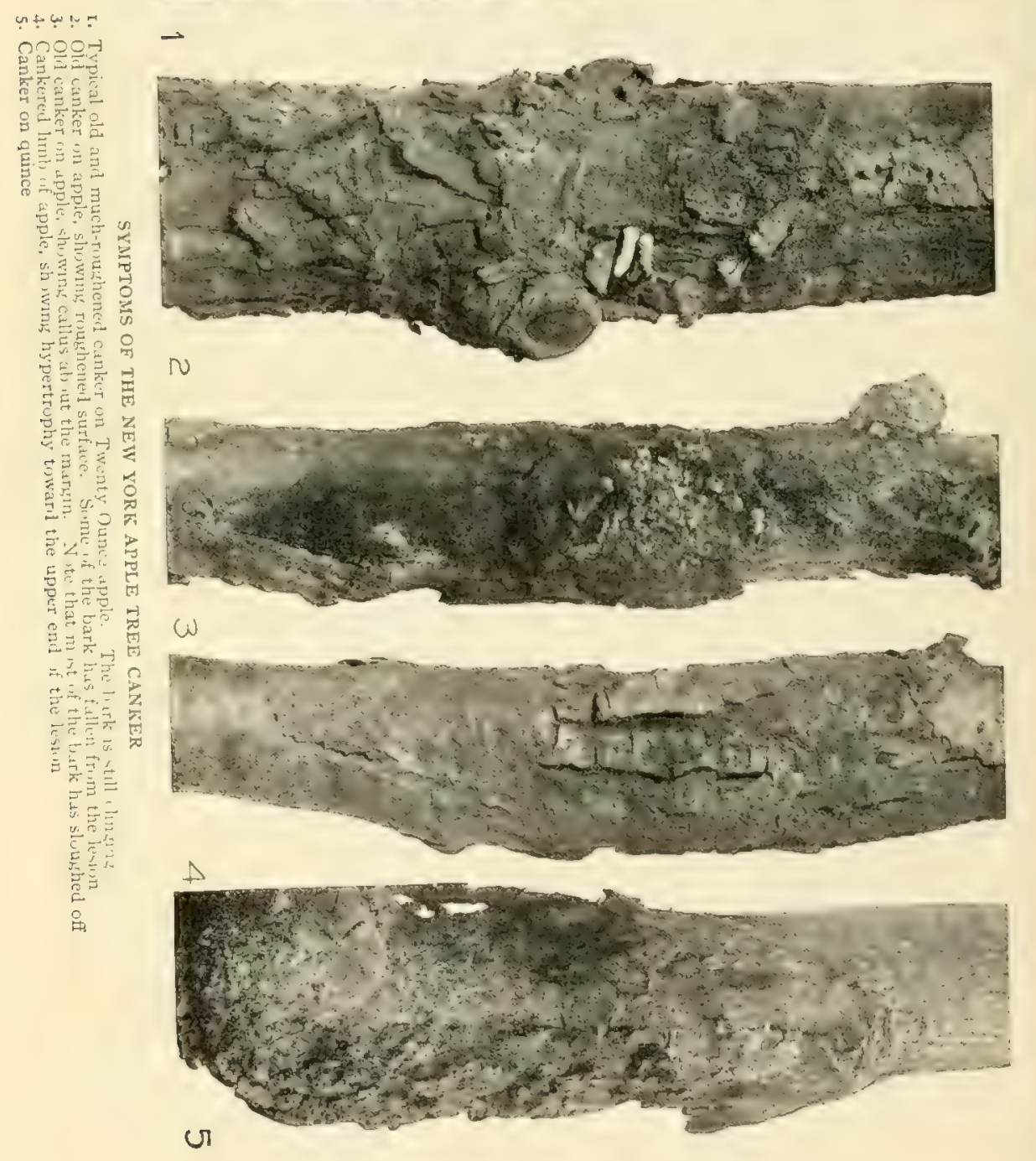




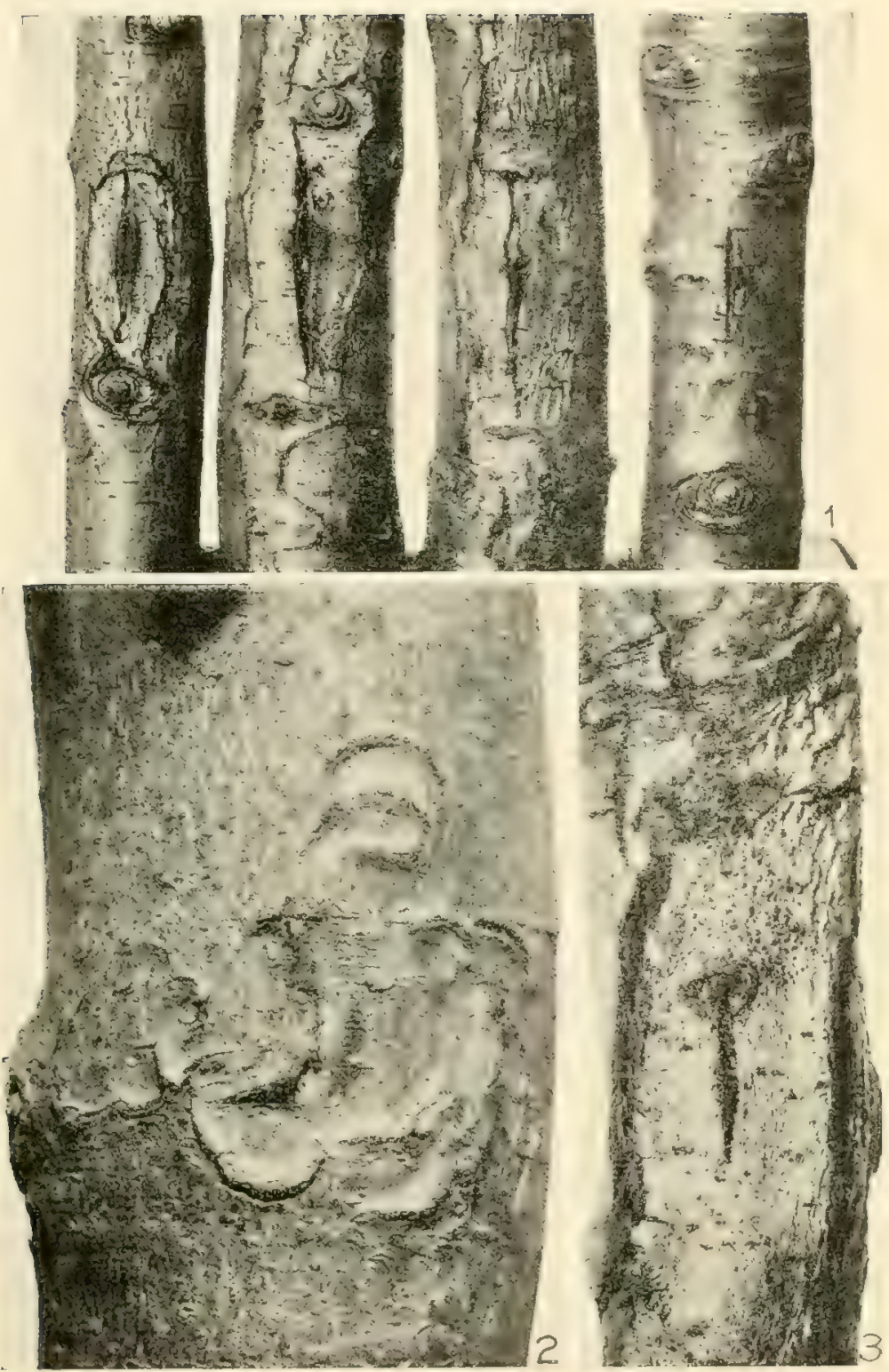

INOCULATION EXPERIMENTS WITH PHYSALOSPORA CYDONIAE

I. The three cankers oul the left produced by inoculating pear with ascospores from apple. Check on the right. Inoculations made June 6, I913, photograph made September 20, 1013 2. Canker on Twenty Ounce limb produced artificially, using pyenospores from apple. Inoculation made June 20, 1912, photograph made September 20, 1913

3. Canker produced on pear by inoculation with ascospores from apple. $11_{1} \cdot 1 \cdot 1$, the

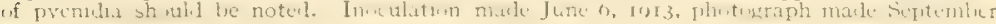
20,1013 

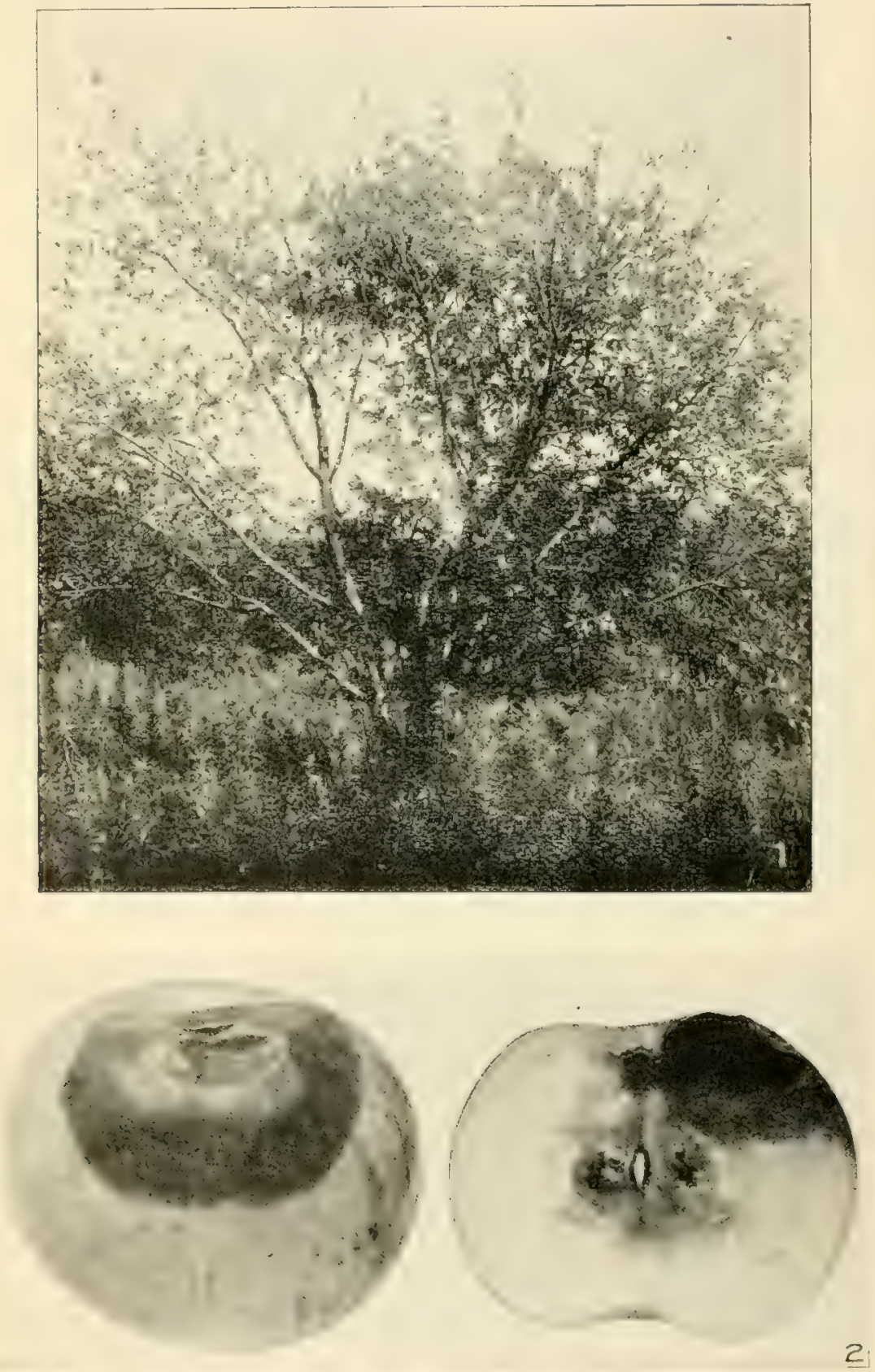

NEW YORK APPLE TREE CANKER

r. Twenty Ounce apple trce, some of the larger limbs of which have been girdled by the fungus. liv lence that this has occurred 15 founf in the defoliated tops of affected limbs 2. External view at left, and internal view at right, of young black rot lesions on apple; the specimen un the ripht shows the tissues involved 

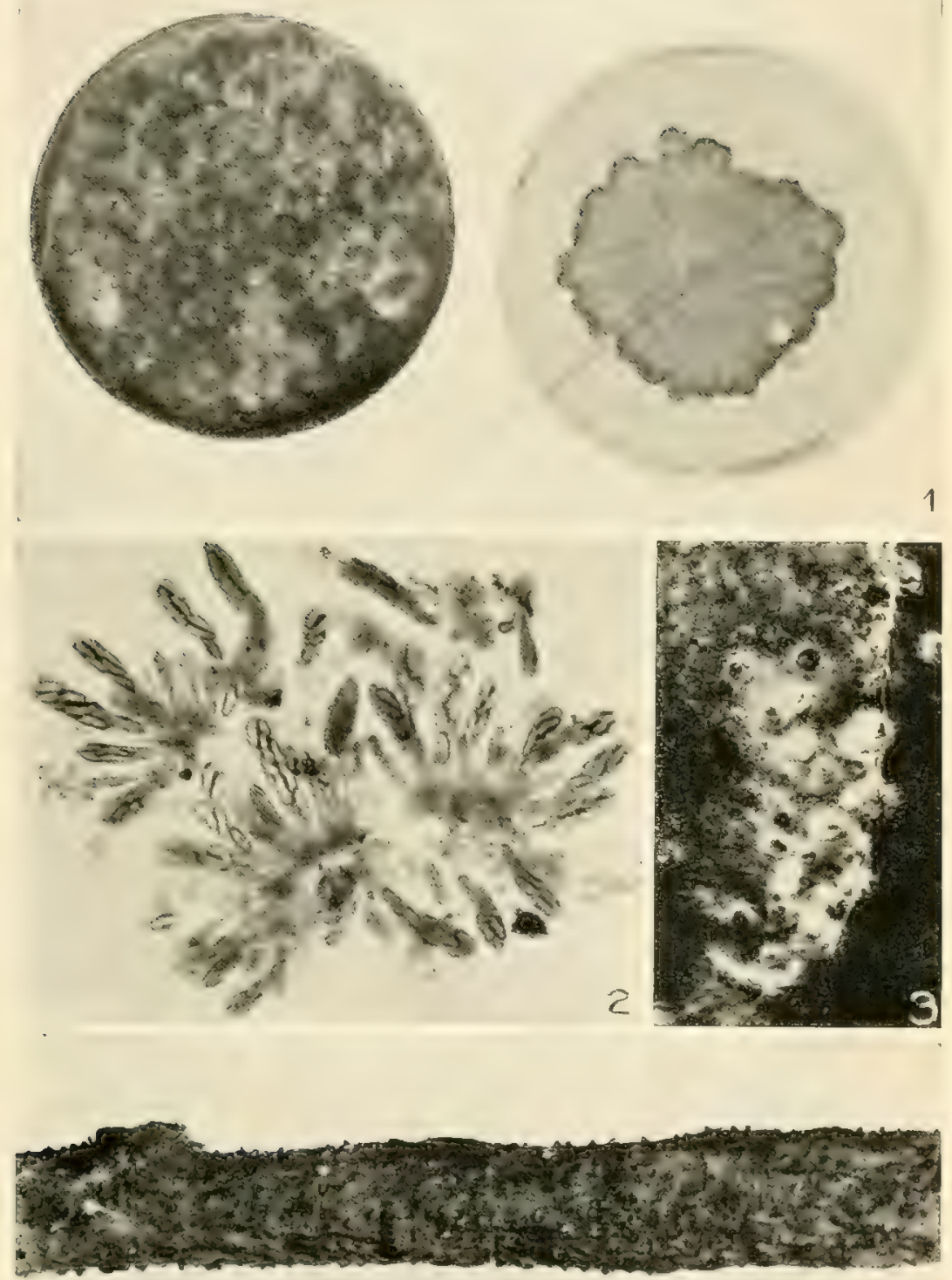

VATIOUS STAGES OF PHYSALOSPORA CYDONIAE

I. Showing differences in growth on nutrient a jar from pycnospores (heavy dark growth an left) and from ascuspores (scant growth on right)

2. Phot micrograph of asci, ascospores, and paraphyses from a single perithecium

3. Sclerotia as they appear in pure culture

4. Twig of apple, showing dark masses of pycnospores which have onzed from the pycridia when the twig was kept in a moist chamber 

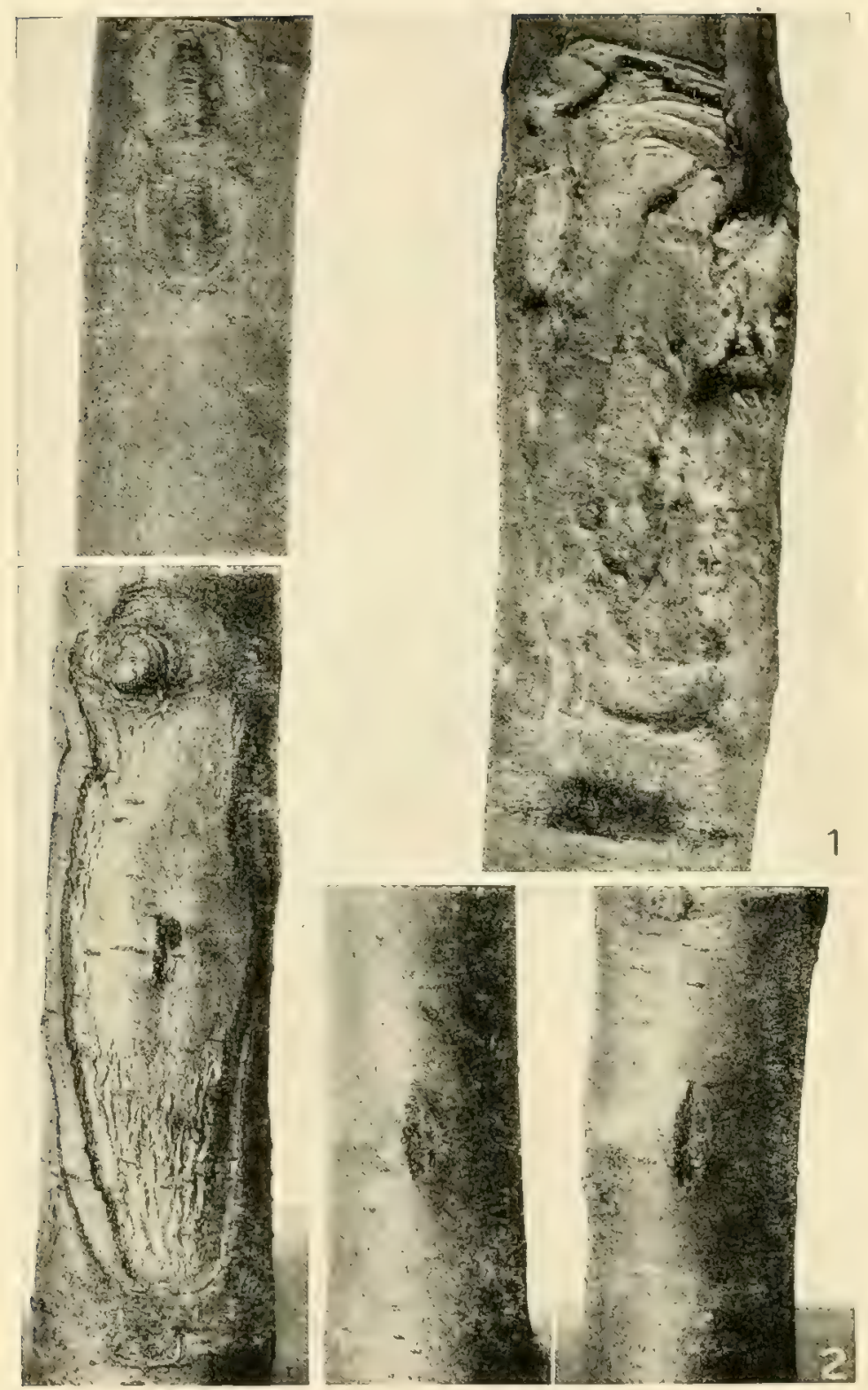

INOCULATION EXPERIMENTS WITH I'HYSALOSPORA CYDONIAE

I. Canker on right, check on left. Inoculation made July I, I9r $z$, using pycnospores from pear, the fungus having followed fire blight. Photograph made September 20, 1013 2. Comparison of two different apple strains on pear. Specir with ascospores from apple. Specimen shown in center inoculated with pycnospores from apple, following fire blight. The very slight infection should be noted. Check on right. Inoculation made June 6. I913, photograph made September 20, 1913 
walled. The innor, thin-walled layer is of rery unifom diamencer. In cases in which the perithecium is depressed, the outer layer is reduced at the base and is from one to three pseudo-cells in thickness, whereas the lateral outer walls are from two to five layers of pseudo-cells in thickness. The ostiole appears as a narrow passage in the papilla, the walls of which show the same distinct layers as those just described for the sides and base of the perithecium.

The asci, with the interspersed paraphyses, ustally fill thie cavity of the perithecium. Arnaud (I9I 2:II) states that in general the paraphyses are formed by rows of

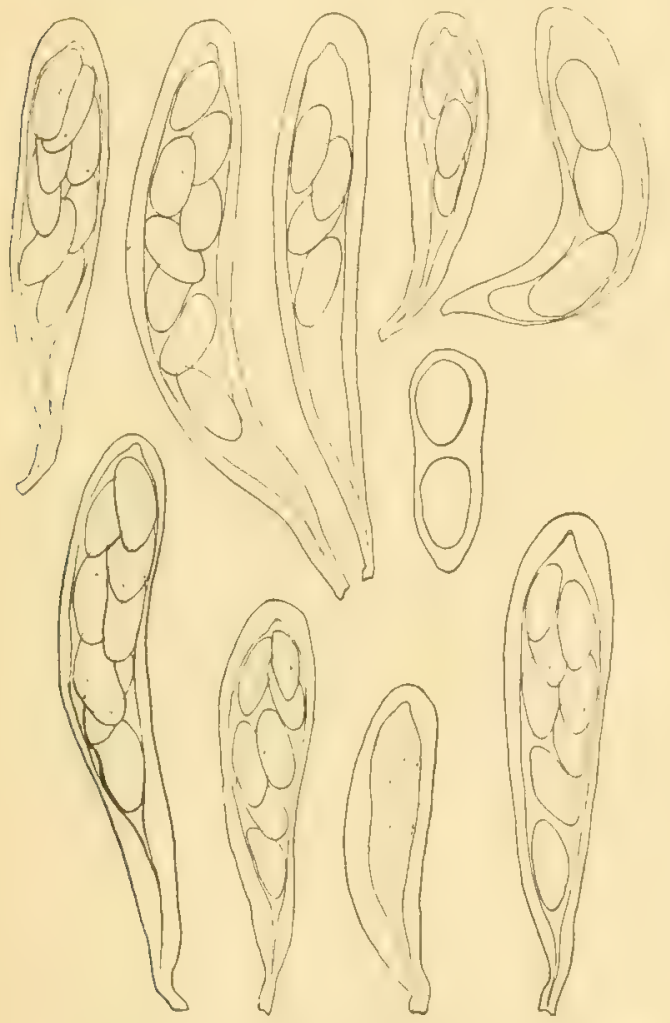

Fig. 20. AsCi OF PHYSalospora CyDONIAE FROM DIFFERENT HOSTS

The upper series represents variations as found on apple bark. The lower series shows variations from bark of witchhazel cells which in the mature perithecil1 m are separated one from another in the form of distinct fil-

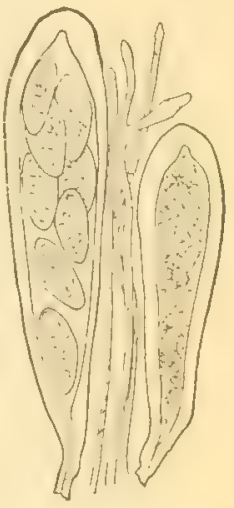

FIG. 19. ASCI AND PARAPHYSES OF PHYSALOSPORA CIDONIAE

Camera lucida draw. ing of asci and paraph yses, showing structure of the latter and typical arrangement of ascospores in the ascus

aments. He says that in certain cases, however, the paraphyses remain agglutinated by their walls and appear in section like rows of cellular cavities, as in Cucurbitaria ( $C$. Spartii and other species). He explains that if the rows of cells are not very numerous the existence of the paraphyses may become uncertain. Arnaud finds this the case with Plyysalospora Cydoniae. The writer, however, has not observed this condition of the paraphyses; to him they appear distinct and non-septate (Fig. I9).

The asci are abundant: asci crushed from noe perithecium are shown in Plate xin, 2. "They are usually clavate, althotgh ther sometimes tend to be crlindrical, measuring 
from $2 \mathrm{I}$ to $32 \mu$ by $\mathrm{I}, 30$ to $\mathrm{I}$ s.o $\mu$. The tip of the ascus is thickened, but a complete canal from the inner wall to the outside has not becn oloserved;
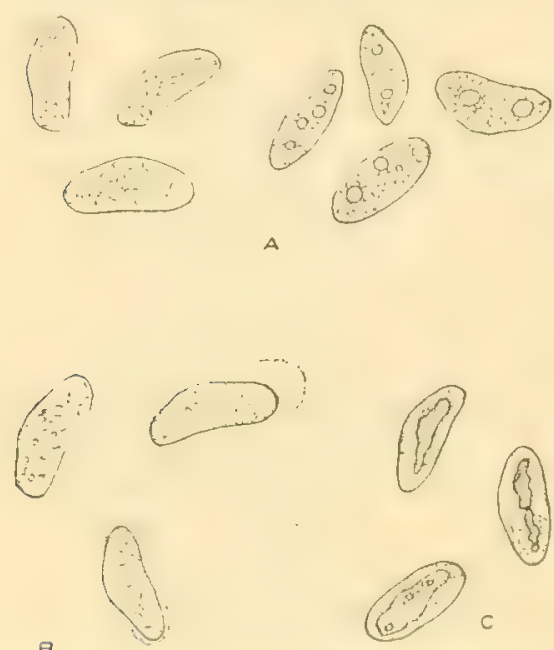

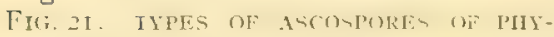
SALOSPORA CYDONIAE

A. Typical mature ascospores as found in nature:

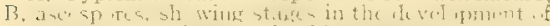

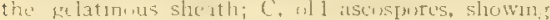
peculyar contents

Not infrequently the apex shows a tendency to be clavate.

The number of spures in cach ascus is typically eight, but exceptions have been found in the fungus on apre te trigs. The variation ranges from two to eight sproses within an ascus, all intervening numbers having been olserved. Fotrespored asci are not uncommon (Fig. 20). The contents of ascospores are either densely srantular, or vacuolate and oily. Two guttules are occasionally found.

proxints. The mopholngy of the pycnidial form of this fungus is varialole (Fis. 22). The pycuilia are situated in the cortical tissues and are usually seattred and distinct, althougl on the same orman of the host they may txe single, conflunt, or united into a stroma. The number of pyenidia per muit of area is usually less on woorly sulustrata than on fruits; on apple fruit there may be from one hundred and twenty to one hundred and fifty pycnidia per square centimeter.

The typical simple pycnitium (Firs. 22, A) measures from 200 to $300 \mu$ in each diameter, whereas the compound fruit body may vary from 200 to fro $\mu$ in the vertical dianeter and from 200 to $720 \mu$ in the horizontal diameter (Fig. 22, ()). Their shape is in gencral the same as that of the perithecia, whose to sububose, and they lave the same distinct outer and inner walls. The thickness of the entire pycnidial wall is variable, 
Black Rot, Leaf SPOT, AND C.NkER of PoMlceots Freits 67

as in the case of the perithecium. The hatal gret is thintere in the case

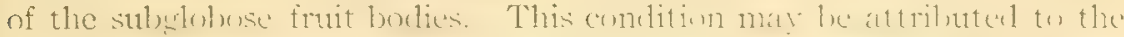
fact that lesis protection is neederl at the hase; or perloph here the thick-

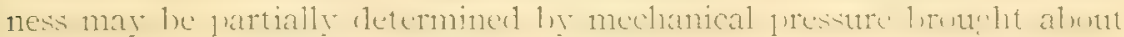
by the resistance offered by the host tissue.

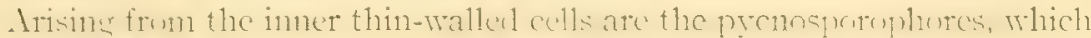
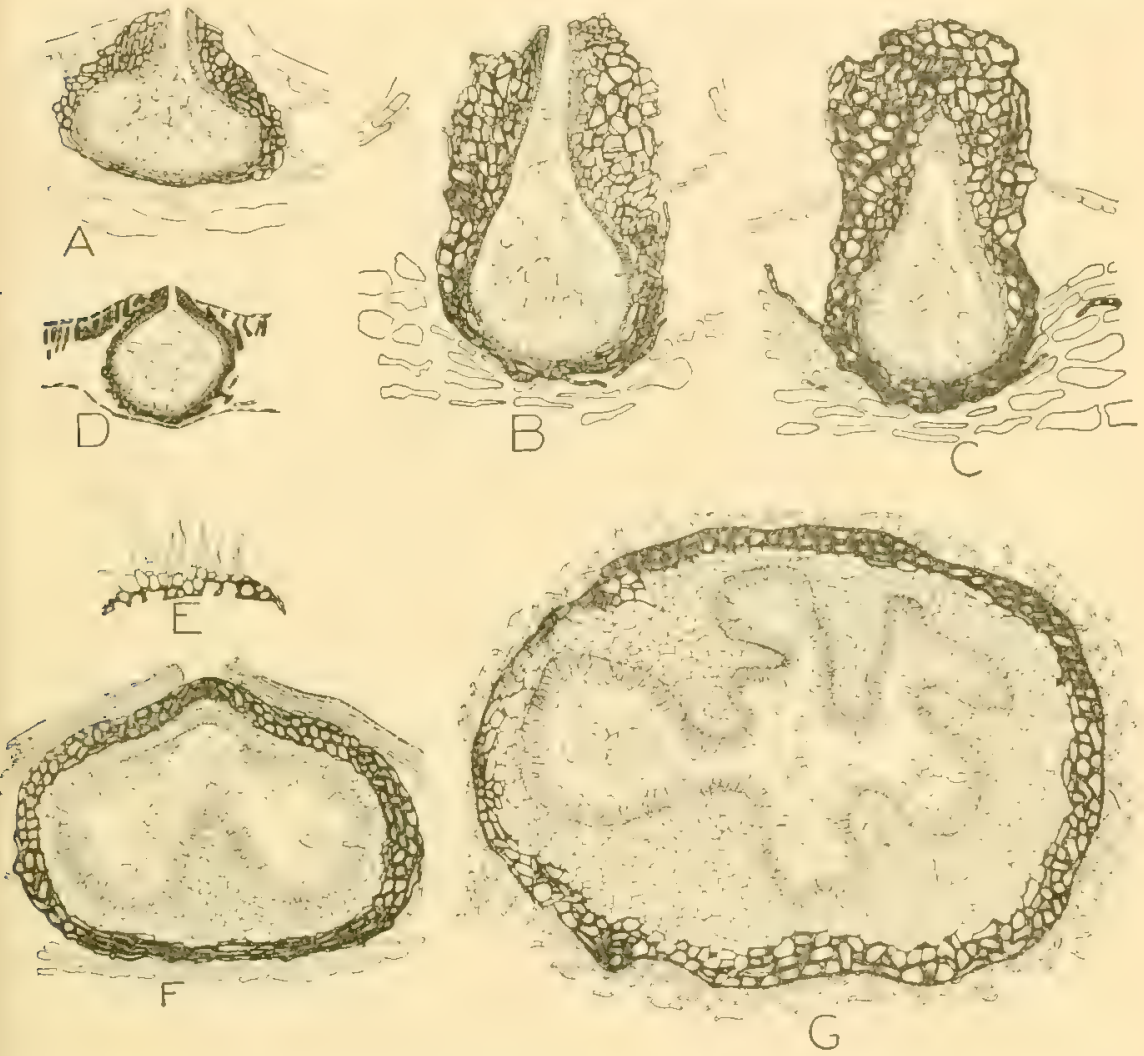

FIg. 22. VARIATIONS OF PYCNIDIA OF PHYSALOSPORA CYDONIAE

A. Typical simple unilocular pyenidium; B, pycnidium with long neck, similar to C but with an ostiolum; $C$. pycnidium similar to $B$, ostiolum not yet developed; $D$. pycnidium from apple leaf; $E$, hair-like outgrowths on the tip of an ostiolum, developed under moist conditions; F, pycnidium with mound-like structure at base; G. pycnidium which approaches in appearance the fruiting body o: species belonging to the form-genus Botryodiplodia

extend entart. They are clatvate, flaste-shaperl, or eylindrical. Ther may

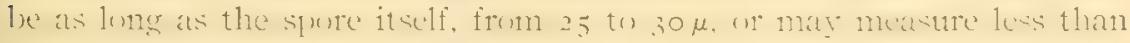
$8 \mu$; the average dimensions are from Io to $I_{5} \mu$ by 3 to $4 \mu$. At the tip of each is developed a pycnospore.

In some casesthere is a mound-lilie strueture at the lade ot the porndium

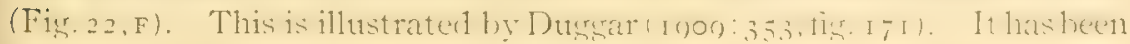
a matter of conjecture whether this may appear wny in an oblinue tan- 
gential section, or whether it is a bilocular tendency. It does not seem possible that any such structure would aplear merely in a section that was not cut rertically. If this were true, the question would then arise as to whether this same apueatrance would not extend at all proints alon!r the lining of the casity, and hence merely make the wall thicleer rather than sive it the aspect just described. It sems, therefore, to be it bilocular tendency.

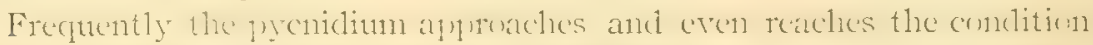

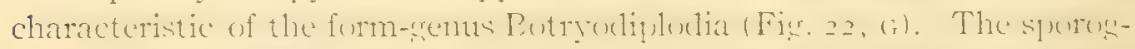

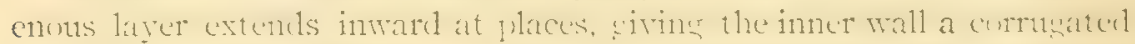
appearance. This condition is fonnd in nature and has been developert in culture from speres in preninlia which oricinally did not show this

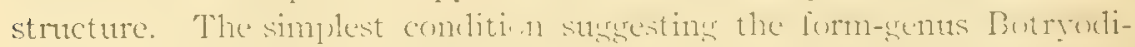
plodia is fomed when a sinste momel-like structure occurs at the hase of the pyeninlium, as previons ly described (Fig. 22, F). Frequently this finds its expression in the form of a bilecular condition, which is a steple nawer the Botryodiplodia type.

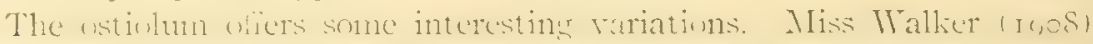

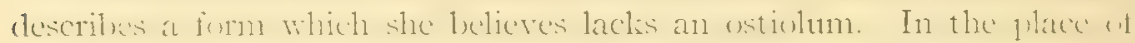

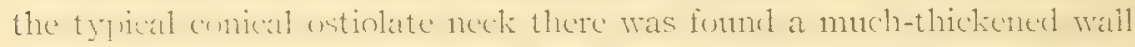
at the alex of the fruting buly, and the papilla itself apteared longer than ustal. The writer has cultured the ustirlate form from an alplete.

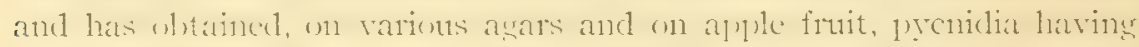

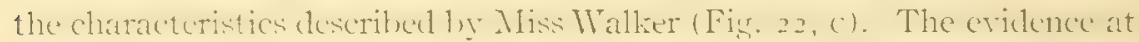
hand indicates that a pore may or mat not he present, depending somewhat on the time of year and on weather conditions. In any case an

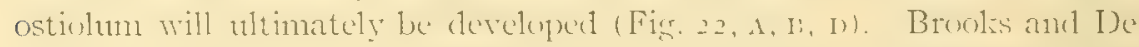

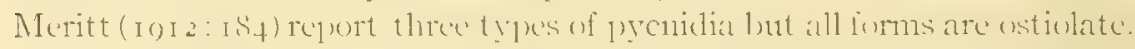

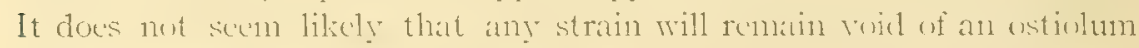
throngheme its history. A streng papillate fom sinilar to that shew

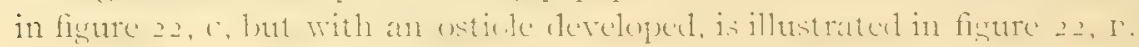

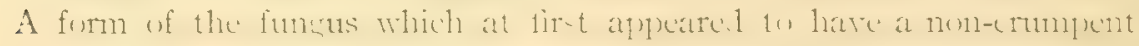

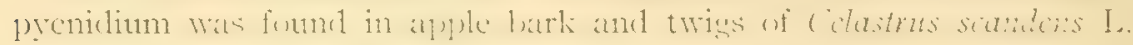

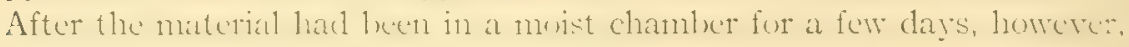
the pycnidia broke through the epidermis.

In conclusion it may be stated that the pycnidia may vary in morpholory on dilferent host plants, get this variation is no soreater than that on the same host plant.

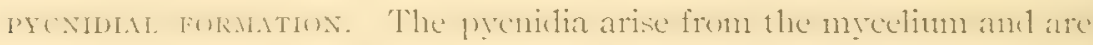
found abundantly on cankers and decayed fruit. Also they may be produced on variots artificial media. They oceur sparingly on spotted leaves. 
So far as has been determined, the process of formation is similar on different substrata. The earlier stages are more accurately followed

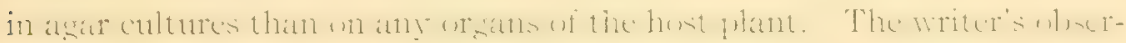

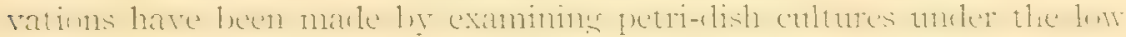

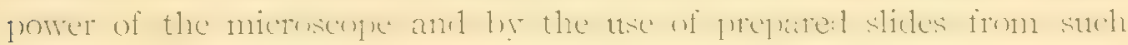

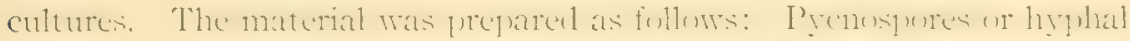

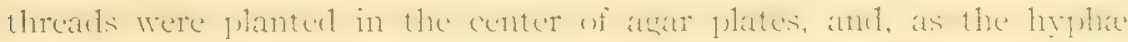

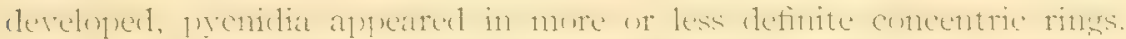

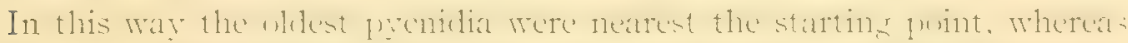
the younsest were found near the marrin of the culture, the stastes between
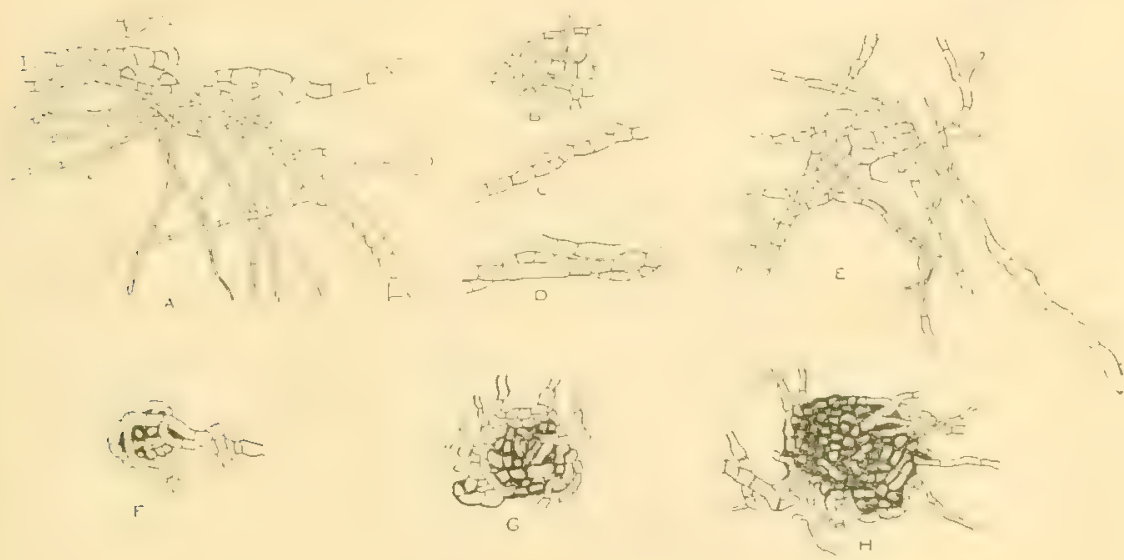

FIG. 23. DEVELOPMENTAL STAGES OF THE PYCNIDIUM

A, Early stage in pycnidial development. The hypha have become closely septate, are broadened, and are beginning to tangle. B. Early stage in the process, showing the origin of hyphe which enter into the pycnidium. Some come from adjacent hypha, others arise from cells of the threads in the immediate tangle. C, Early stage. Branching of hypha, preliminary to coiling and twisting as in D and F. D, Early stage. Twisting of hypha about one another, E, Early stage, showing symohyon genetic and meristematic tendencies in pycnidial formation. F, G, H, More advanced stages in the process of pycnidial formation.

the two leing intermediate. Blocks of atar were cut ont from the dish. fixed, ath imberted in paraffin. 1 sinsle section frequently inclutes

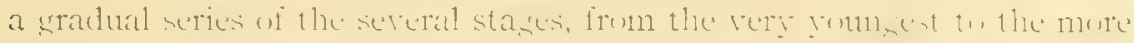

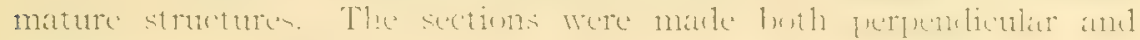

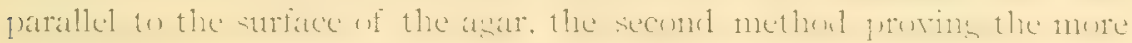
satisfactory.

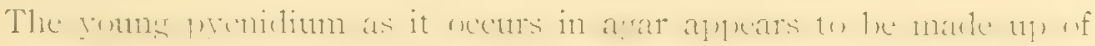

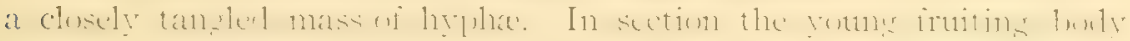

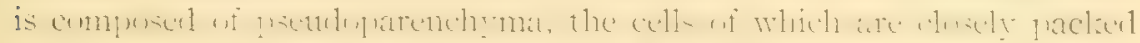

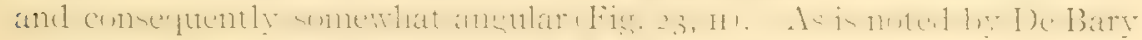

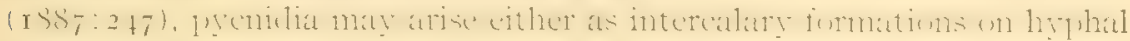

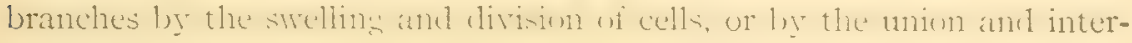


weaving of mycelial threaks. The fomer process is termed meristogenetic and the latter smohregenetic. A third pescible method, not unknown among the fungi, is by a combination of these two processes.

Potebnia ([1)10.021, in a nute on Sphacropsis psomdodiplodia (Felil.) G. Del., states that the prenidia arise meristogenetically. The writer was for some time under the impression that this was the character of the process. lout this oplinion was hased on observations of later stages rather that on the earliest steps in the development. The dense predtoparenchyma of the mature fruit buries suresests meristematic divisions, but apparently the structure, for the most part, arises symphyogenetically (Fig. 23).

In agar cultures a group of threats may be olserved to be directed

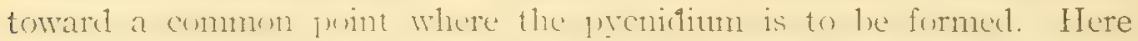
the hyphe are compuset of cells from 6 in $7 \mu$ brombl, their length varying from 20 to $70 \mu$, always longer than broad. In the region where the pyenditum is 10 be developed. the cells become noticcalbly shorter by the laying down of netr walls; the cells also increase in diameter by growth, and the hophe increase their numbers hy branching (Figr 23,A). This stage is observed with ease in petri-dish cultures.

The behavion of the threads in the formation of the pendotarenchyma is varied and the proces is somerhat indefinite. The mecelial branches that enter inte the structure maty arise from the short cells ( Fig. 2.3. A), or they may grow in from atjacent hyphe (Figr. 23, E). The interspaces foume in the earlier stages are filled ly the srowing in of these branches and by at buditing-like action of the hyphal colls bordering the space (Fig. 23, B).

Serial sectims show that there is considerable coiling and ynarling of hyphle. Threats may twist alont one another for some distance

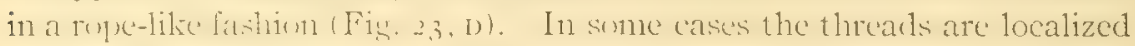
in their intertwining so that the restlting structure becomes a knot or

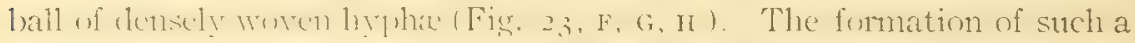

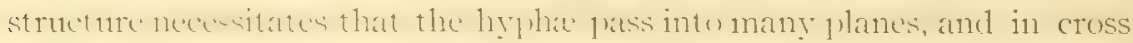

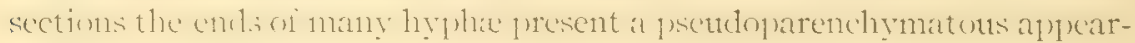
ance (Fig. 23, $\mathrm{H}$ ).

In the intertwining process, hyphe may conjugate in an H-shaped fashiom. In some cates threals that are paralled probalny fuse side by side, although the evidence for this is not complete.

The next important stage is the formation of the cavity. At first no differentiation of the closely tancled mass of threads is shown in the

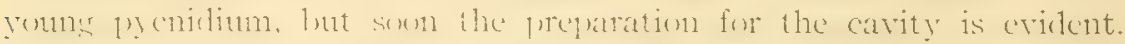

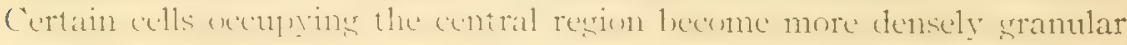
than the surrounding cells. This appears to be the begrinning of the 
cavity. Later stages show the hreaking demn w thes colls, and finelly an oval or a globose cavity is formed. Baccarini (1) foo:(o) states that these contral cells transform by a mucilitymons froxess, ind that the carity is enlarged by the grelatinuts center's absurbing water and exerting a pressure on the sporogenous lager. He emplasizes the importance of the central "tissue" and expresses the opinion that it has a sperial function, believing that it is destined to becomesponoments whereas the onter surrounding cortex only furnishes nomishment to these cells.

The formation of the ostivle is smilar to the pruexs exhitited by the

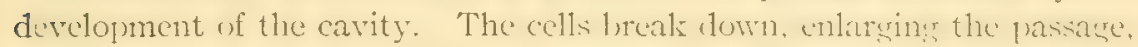
and finally the wall is definite and continuots with that of the spore carity.

The spore-bearing area oceupies almost all the space not included by the ostiole. The cells lining the cavity arch outward, and continued growth results in the formation of a stalk. The tip of the stalk sivells, and ultimately a mature spore is cut off (Fig. 24). The further development of the pycnospores has been discussed.

Provospores. The morplookery of the prenospores has been more cartully sturliced than that of the pycnidia. In the same and
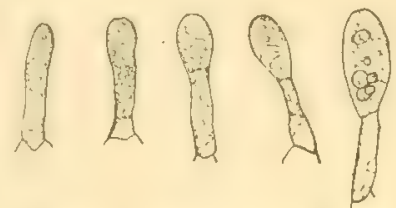

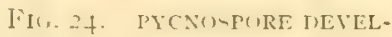
(1)MLNI

Situr - 1. the i ranti in of a pycnospore from a conidiophore in different pycuidia on the same ancl on diflerent plants, wide variation with respect to size, color, sliape, and septation have heen observed (Fig. 25).

The arerare inature yycnospore measures alunt 12 hy $25 \mu$, although the range in single or in different pyonidia on the same or on different hosts or host parts may le comsiclewt)le. From the muswrement of hundreds of pycuospores, it has been fommd that they range from 7 to I $6.2 \mu$ broad by from in to $36 \mu$ loner, while the areraeses from different hosts range from 9.5 to $I 3.3 \mu$ by 19.8 to $27.8 \mu$. Spores on the apple show a slight variation on the different organs, as folluws: on the fruit, I0. 6 by $25 \mu$; on the twigs, I I. 6 by $23.8 \mu$; on large limbs, I 2.9 by $24.9 \mu$; on the foliage, I2.3 by $23.5 \mu$. Paddock (IS9g b:I95, table I) notes considerable variability with respect to size as the sprores necur on different plants, but he says: "Yet the spores poroluced on apjle fruits inneulated with cultures from either host, are of the same size and character; similarly, though not shorn in the table, when pear frese are inoculated with cultures of Sphacropsis talien from apple trees the resulting pycnidia and spores are of the arerage size of those foumel in nature on pear tree bark."

The mature pycnospores are brownish, varying from a very light to a darli fermeninous color. The color clarkens with ace, so that the very youngest mature spores are hyaline. The question of the maturity of 
these colorless spores has frepuntuly arisen. The writer has geminated them, and is of the opinion that they should be regarded as physiologically mature. The hyaline color is replaced later by a yellowish green tinge, and finally a brown of varying density is assumed, the spore becoming very dark lown in the funal conclition of coloration, as noted above.
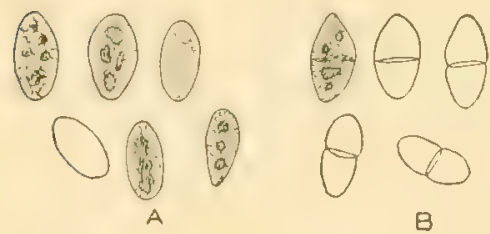

B
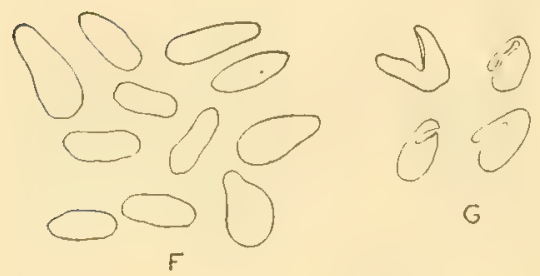

G
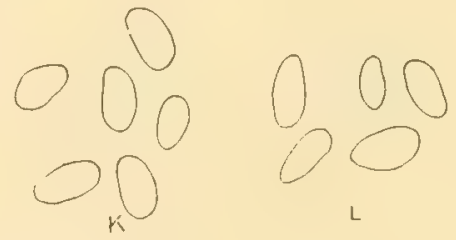

L

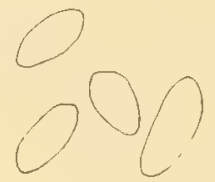

H
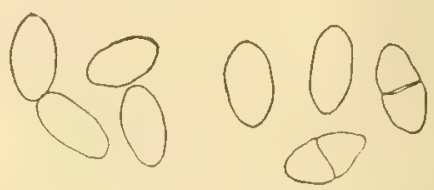

E
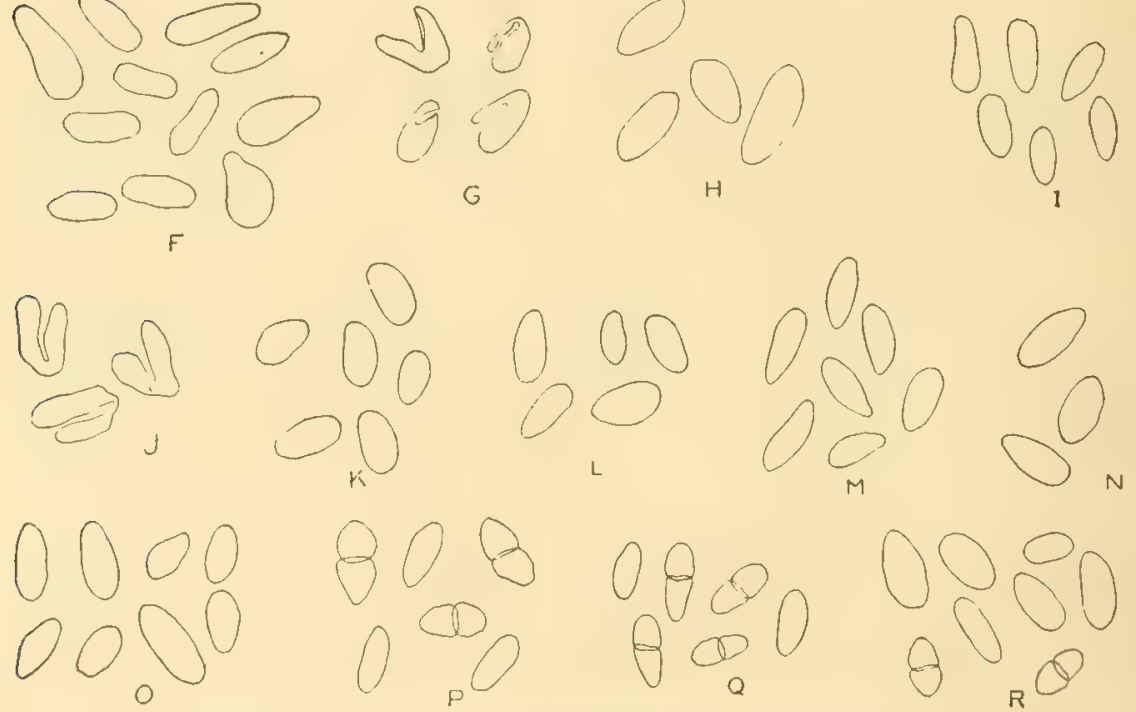

Fig. 25. VARITIONS IND TYPEM IF PYCNOMPORES OF PHYSILOSPORA CYDONIAE FROM VARIOUS HOSTS

A. Typical unicellular pyenospores; B, typical bicellular pycnospores; C, three- and four-celled pyeno-

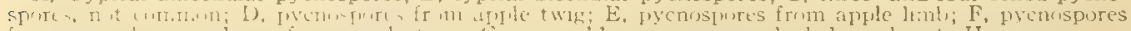

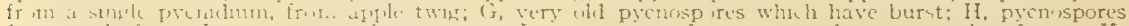

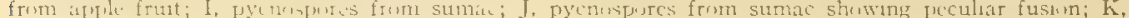

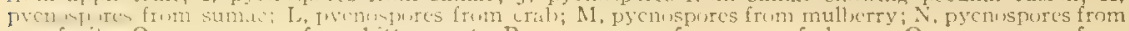
rose fruits; $O$, pycnospores from bittersweet; $P$, pycnospores from rose of sharon; $Q$, pycnospores from witch-hazel; $R$, pycnospores from spicebush

The several sharles of color may le represented by the spores of a single pycnidium, although the majority are uniform in this respect.

The trincal penosinore is ellipsoidal, frequently tapering slightly toward the batsul end (Fin. 25, A). The shape also is a variable character, howerer. Pyrifom spores may accompany ellipsoidal, globose, or somewhat elongated forms. 
The question of septation of pyenospores is of impurtance lucause of the fact that it involves the systematic value of the character, or variation if it be so called, in separating the fommernera siphaterpsis and Diplorlia, and becanse of the physiological significanee of it formation. In nature, three pressible conditions exist with respect to the presence of one-and two-celled spores. I grenidium may contain only one-celled

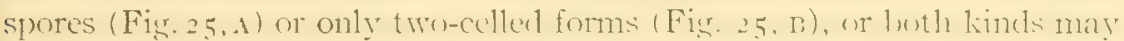

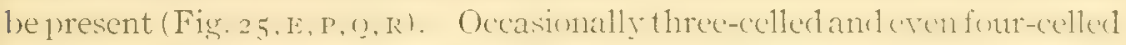

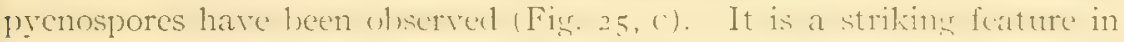
this resard that no strain has come nunder the writer's of servalion that will not produce two-celled sjures. Jut what factors induce cruss-wall formation is a matter not well understurl. Matture uniedlular pures plarerl to germinate. whether semninating at onee or non, will smon mes develop) a septum. Acrain, spores that are formel scattered alunt on the hartio of the host plant show the bicellular comdition. In rery darti spures the crosswall is not always readily visible and may be casily overlooked.

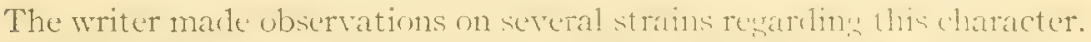

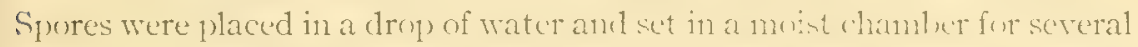
hours. At the heorinning and at the curl of cach experiment the spores were examined for septation. The strains when collecterl, with the

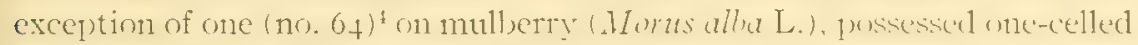
spores only. After being placed to semminate, or in nature after they had oozed forth on the substratum, septa lugan to apyear and the prencentases were as follows: one-cellerl spores, from two to ninedy-five fer cent; two-celled spores, from five to ninety-eight fer eent: three- and fourcelled forms, rare. The areware for all such of servations shows that the percentage of one- and two-celled forms is about equal.

Cultural studics were macte of an apple strain (no. S2) with reference to this and other morpholosical characters. A single cllipsuidal, hrown, one-celled pyenospore, IO.S hy $21 \mu$ in size, from a jerniclium in which all the spores were one-cellerl and typically like the one descrilert, was isolated on March 3, igr 3, and a pure culture was developed from it. Examination of the culture at intervals showed the dereigument of hyaline, Nacrophoma-like spores. At the end of twenty-futr days these had becone brownish, and, while the nujority were cllipstidal, averasing

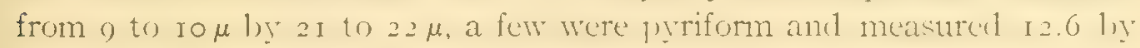
$30.6 \mu$. At the cud of fifty days an occasional spore was found with a cross-wall; after eishty days thirty per cent of the speres were twe-cellet, and on May 27 sixty per cent were bicellular.

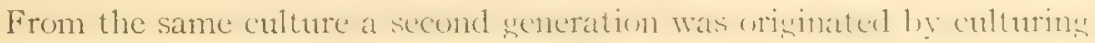

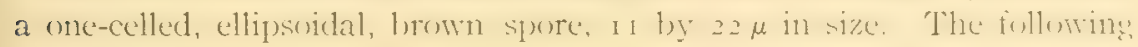

- The specimens were numbered consecutively regardless of source, host, and other considerations. 
notes were taken: Within two wecks an occasional spore measured 7.5 by 2 i $\mu$, although the usual size was from 9 to $10.8 \mu$ by 19.8 to 26 . I $\mu$. After forty days several (wo-celled spores appeared. At the end of two months, fifty per cent of the spores were one-septate.

A third gencration was initiated by planting a spore from the second generation, of the same shape and measurement as the preceding. After one month twenty-five jer cent of the pycnospores were of the Diplodia type.

Another series was stulied, using a two-celled spore from a pycnidium in which hoth one-celler and two-celled forms were present. Within one generation a single sprore, 10.8 by $21 \mu$ in size, two-celled, brown, ellipsoidal, harl developed offisming showing the usual color variations that is, from hyaline to greenish, and finally brownish. After eighteen days some of the spores measured I 2 by $28 \mu$, the average being 10.5 by 2 I $\mu$. Septation bexan to show after fire weeks, and within eighty days sixty per cent of the spores examined were two-celled.

Apparently, from a single jycnidium in which the spores are of a given type there may develop in succeeding generations a wide variation in size, color, shape, and septation. In an carly stage the Macrophoma type may appear in both size and color; later the Eu-Sphaeropsis type, one-celled, hrown; and finally the Diplodia forms. The variable shapes that may be found in the generations succeeding a given type indicate that two-celled forms may the mere deviations in the life cycle. On the other hand, Brooks and De.Meritt (ro12:Ist) report from New Hampshire a large-spored form which holds true to its morphological characteristics for several generations.

Markings on the wall of the pycnospores are reported by Griffon and Matublanc (1)10:312). These authors claim to have discovered an undescribed character of the spores of this species, namely, a shagreened wa11. This character is not reported elsewhere in literature, and has not been ofserved by the writer among the several strains studied, including Dr. Peck's type specimens of Sphatropsis Malorum Peck. ${ }^{5}$

Long, slender boclies, measuring about $1.5 \mu$ in diameter and often $50 \mu$ in kngth, have becn observed interspersed between the pycnospores of a strain from apple twigs. They are not of frequent occurrence in the experience of the writer.

MYcuifur. The myculium is composed of septate tubes, monopodially branched and comparatively broad - heing on an average about 4 to $7 \mu$ in dianeter. In the young hyphe cross-walls are rare, but in older branches the threatis atre often short and frequently with bulging lateral

${ }^{5}$ Following the Vienna Code published in 1006 (Wettstein, R. von, Wiesner, J., and Zahlbruckner, A.,

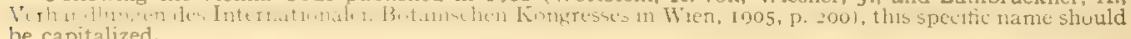
be capitalized. 
walls. Color is lacking in youner aerial threads, but as age increases a greenish yellow, then bluish green, brown, and finally dark bromn, lute is assumed. In mass the mycelium appears black. In cultures lacking potassium a violet tinge has been observed. The walls of the hyphæ are relatively thick, and sometimes a decided double contour of the membrane is visible. The appearance of the cell contents

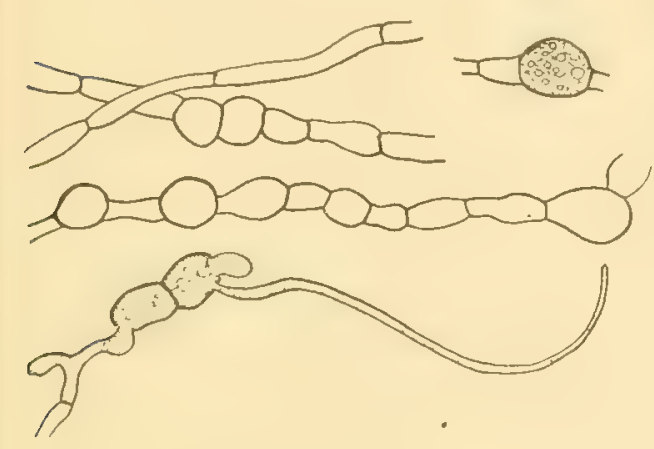

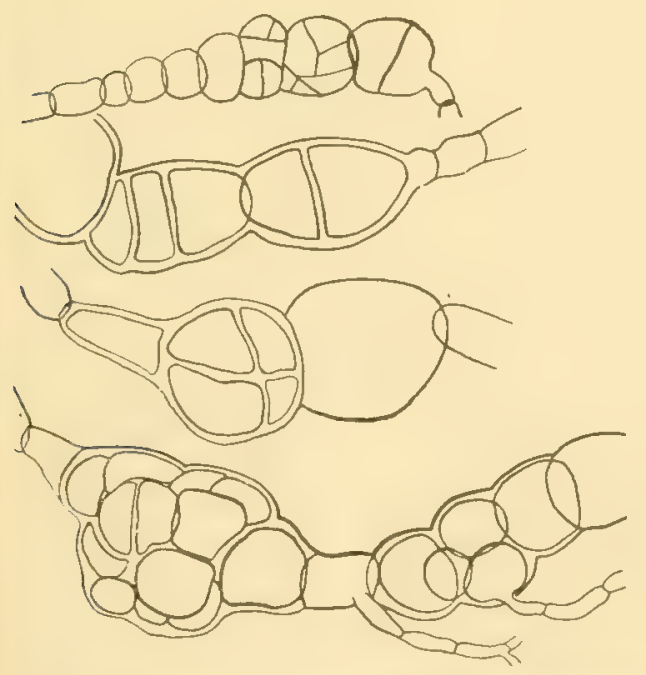

FIG. 27. CHLAMYDUSPORE: OF PHYGALOAPORA CYDONIAE

Types of chlamydospores found in pure cultures

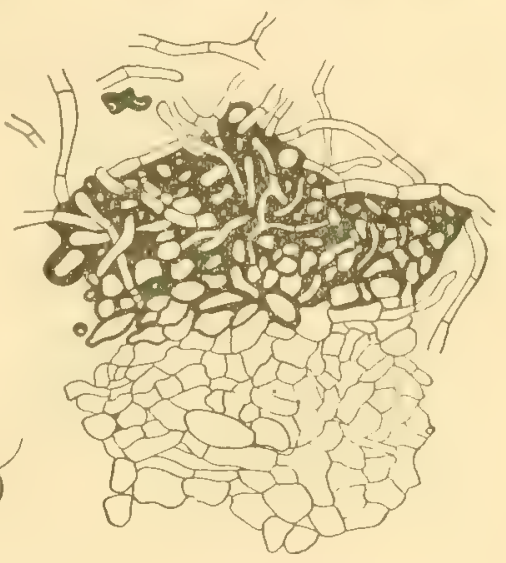

FIG. 26. PART OF CROSS SECTION OF SCLEROTIUM

varies, apparently depending somewhat on age and nutrition. Young and well-nourished cells are densely granular, while older threads contain vacuoles and glycogen drops in abundance.

SClerotia (Plate xiII, 3 , and Fig. 26). Sclerotial bodies have been found in nutrient media of high sugar content and in oat agar cultures of ascospores from Hamamelis virginiana. Walker (1908:38) reports the development of sclerotium-like bodies resembling pycnidia on artificial media. They have also been observer by Baccarini (1890:67) just under the skin of the apple.

CHLAMYOOSPORES (Fig. 27). Chlamplospress have doubtully heen ohserved by the writer in host tissucs. In a forv cases a surwestion of 
such a boxly was found in anple hurk. In chl cultures on various artificial merlia, laries, thick-walled, interealary, brown. spore-like bodies are sometimes fusent in abuntance. They were also cobtanct casily by transferring hits of mycelium to stcrite water. The g have been observed in agar cultures that have lecome contaninated by bacteria, being found more

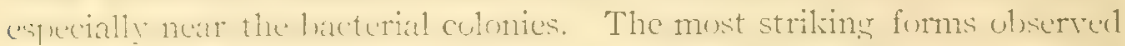

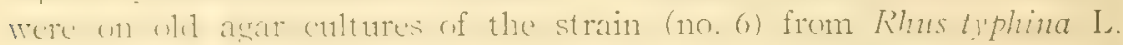

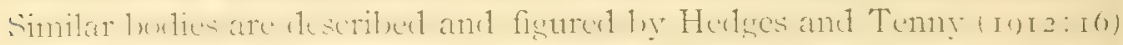

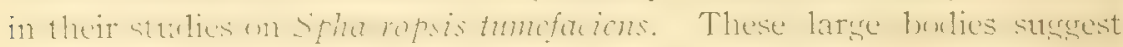

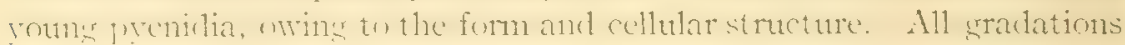

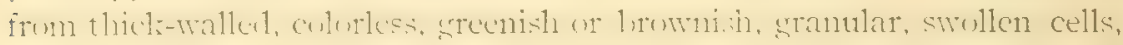
occurring singly or in chains, are very common in artificial culture. These bodic: have ben serminated ly the writer, the serm tubes developing into hyphe of the usual type (Fig. 27, near top).

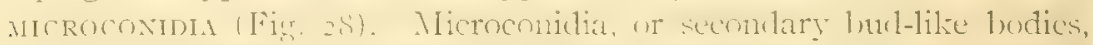

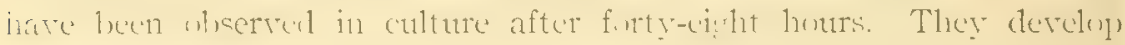

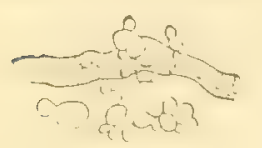
as swellings near the tips of the growing hyphæ. They are globose or somcwhat pyriform, measuring from 3.6 to $6.3 \mu$ by 7 to $\mathrm{I} 4.5 \mu$, averaging 4 by $9.5 \mu$.

IEAST FORMS. Alwood ( $I 898 \mathrm{~b}$ ) records the dis-

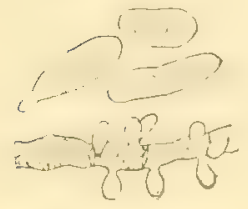

Firs, 2i Milk $\left.x^{\circ}\right)$

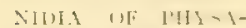
LUIPKAC CHNIAE Showing microconidia develnped on the mveelial tist it $1: \quad$ i.i. \& i. $1-$

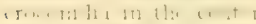

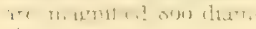
eters

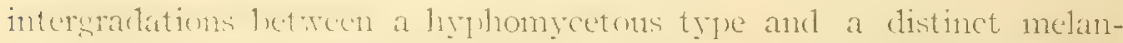
chinacens type of stmeture oceur in cultures. Sictie maty he present in some cultures and abrent in whers, while paraphyses are renarded as of

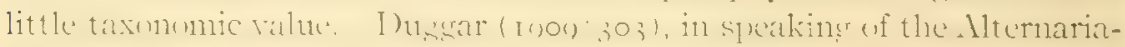

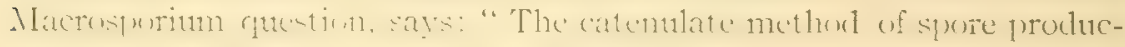
tion hats ben repurterl only in altificial cultures in this case, and it is

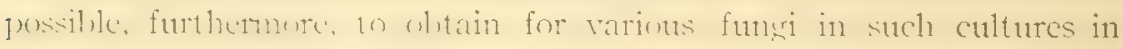
Eeneral many wiations from what would be considered the nomal type

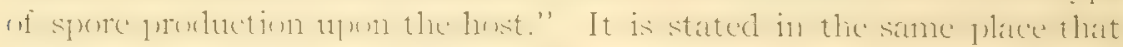

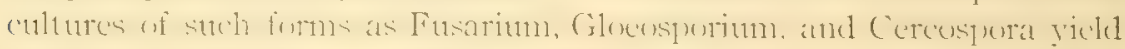

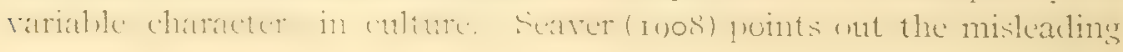




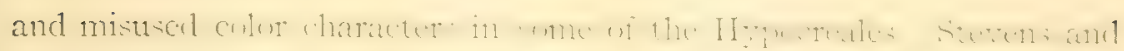

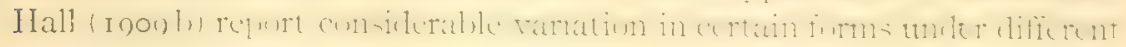
environmental influences.

\section{PHYSIOLOGY}

METHODS OF ISOIATION. The chice melluxh nat in whatin the

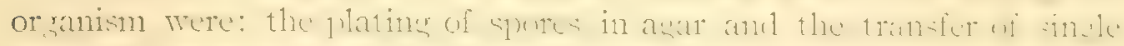

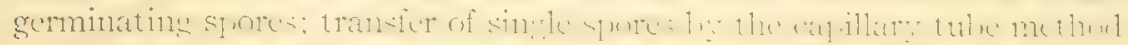
as described previously by the writer (I9I3:291-292); planting bits

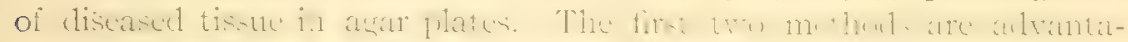

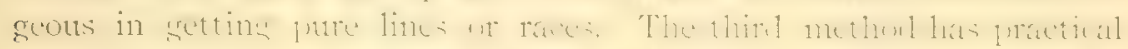

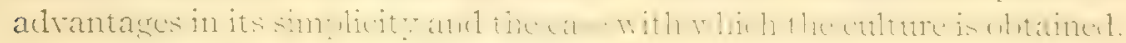

CULTURAL CHARACTERS — GENERAL. The ability of this fungus to

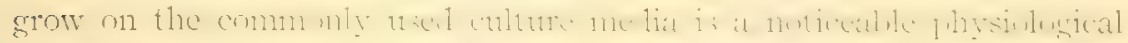

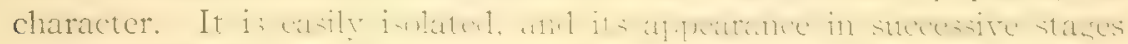

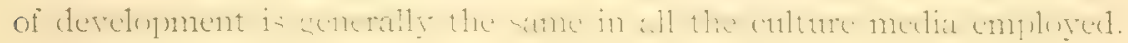
The colonies are at first cottony; after from two to five days the sub-

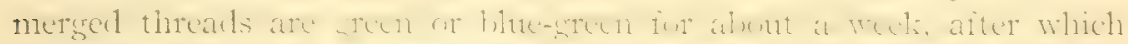

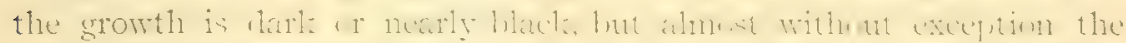

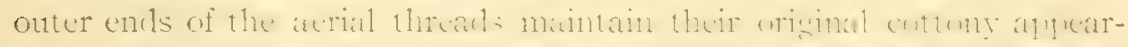

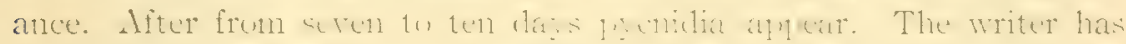

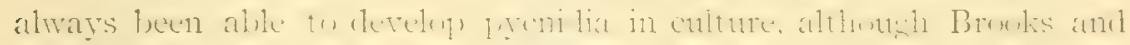

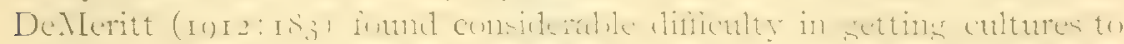

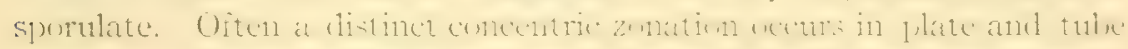

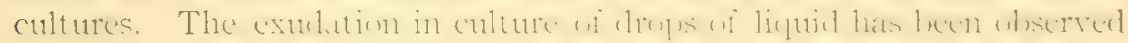

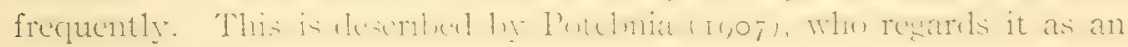
excretion product.

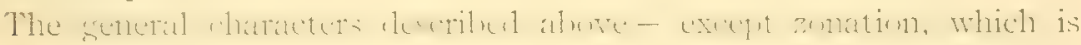

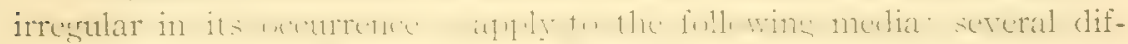

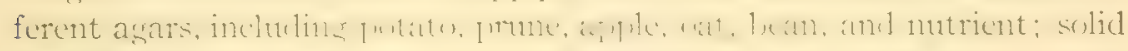

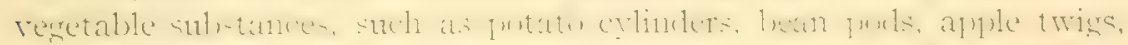

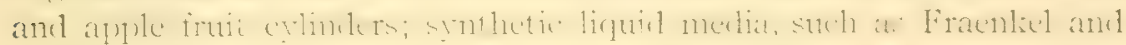
Voge's, Cohn's, Rankin's, and Uschinsky's solutions.

CULTURAL CHARACTERS - SPECIAI. The writer (I9I3:292-293) has

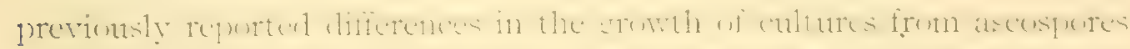

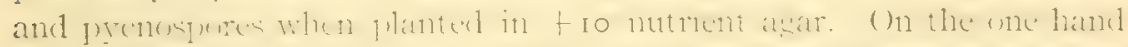

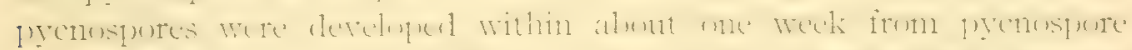

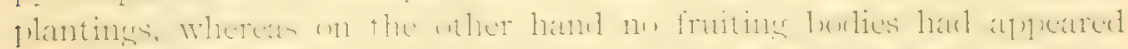

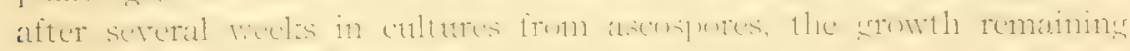

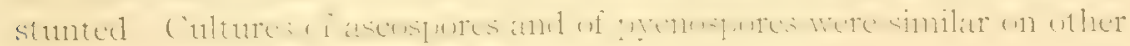
media (Plate XIII, I).

PROTOPLASMIC STREAMING. Protoplasmic streaming in the hyphre

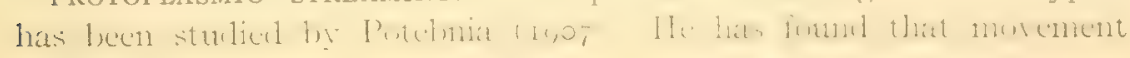


berins with the rermituation of the yycumspre. The direction is furst towarl the tip, srme stanteles mering more rapidly than others. On reaching the ti]), these that have moved the faster direct their movement backwart, in simc ases fomming smoups. The streaming is not dependent cithe1 on cvalumation thronets acrial parts or on the structure of thr:

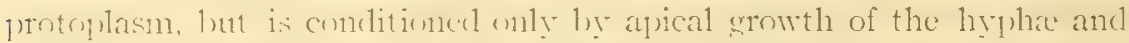

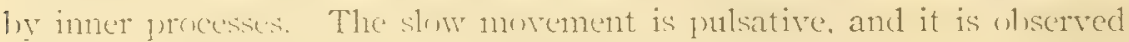
that incrused lomperature acolerates forwarl movement and conlins often induces hathward fow. It is suggester that the streaming is similar to the slow movement observed by Van Tieghem in the hyphat of the Mucorales.

\section{PATHOGENICITY}

The alsility of the oryanism to produce the rlisease, particularly the loaf spot and canker forms, has leen a matter of no little consideration. The diffectlics that are met in attemptines to infect various plants have bronerlet out, uret omly some conflicting results, but also, what is more cucouraging, some interesting prolslems with reference to the catusal aerent and the taxnmomic relationsilip of the so-called species on the different hrest plants. The exoss-infection of the sereral hrosts, and the

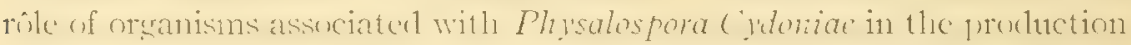
of the lesions, are points that hare a puactical and scientife huring on the rhole problem. The difierent formes of the discase are followed in the succeeding discussion.

BLACK ROT OF APPLE. The ability of the fungus to cause decay of fruts was citaldisher, after a fashion, in rigs ly Peck, who writes (IS79:20) that "the discusc is contasions, and may be communicated from one apple to another."

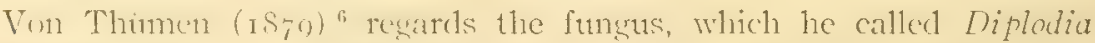

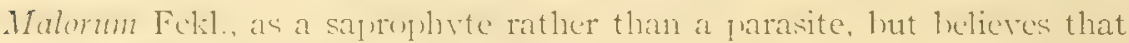
it is capable of attacking somnd fruit and is al)le to cause notable injury in storage.

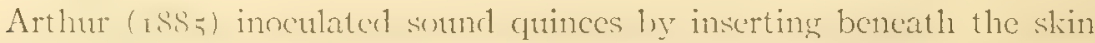
a bit of liscased fruit tissuc containing spores of the fungus (which he calls Sphacropsis ("ylomiac C. \& E.). The increnlated fruits were placed under a ledl jit". Arthur says: "The spores germinated. and the rotting progresied slowly, when, on the twenty-second lay, the spot harl reached an inch and a hilf in diameter, and the frut ine points had hesum to ajplear."

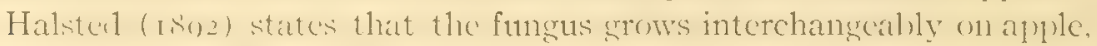
quince, amb pear fruits. If reperts having corroborated his laburatory experiments by field observations.

6 Original not seen by the writer; context taken from Baccarini (1890: 70). 
Sturgis ( $1 S_{94}$ ) made inoculations both in the field and in the laturatury. confirming the work of Halsted ( 18()$\left._{2}\right)$ and showing that when the skin was not broken previous to inoculation the fruits remained in a sound condition.

Padkock (ISog b: : 85 ) producel black rot of apple artificially within a ferv hours by the use of the bhek-spored fungus, perticlia appearing after sixteen days. Asain, Patdock states (1)age ro, of sume references that the fungus from pear, quines, and Japances plum produces rot in apple, pear, and quince, if the slin is puncturel atnel musture is furnisherl.

More recent inoculation experinents are repurterl he Wallew (I)os's. Morse (1909), Arnaud (I9I2), and others.

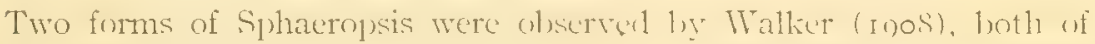
which were capalse of producing black rot - the newer form, howerer. being a more virorous rot producer. The morphological differences have been previously noted.

The writer made several inoculations (tables $x$ and 2) on apples of different varicties, using different strains from lark ancl fruit. In all cases pure cultures of the fungrus were visul. In malsing wound to serve as infection courts a flanned scalpul wats empleyed. Material transformed from the culture consisted of mucclium and spores; this was inserter in the injury previously made, and the fruts were plated in sterile molst chambers. It is to be noted from table I that difierent strains vary in their ability to infect the same raricty. Attention is called to a compunison of strains $1,2,3$, and 4 . All were vised on Baltwin apyles on the same date and under similar conditions, yet the results were different. Strane $\mathrm{I}$ and 3 showed slow decay, with no jow nidia after nincteen days. On the other hand, strains 2 and + caused rapid decay and almundant pyenidia in the same length of time.

As shown in tathle $\mathrm{I}$, nine different varictics were inesulated with the same culture, the results being variable with reference to decaly, fruit body production, and the formation of concentric rings.

It has been commonly olserved that older cultures prouluce the disease less readily than do younger cultures. The lest restits were obtained by the use of cultures not more than two months old.

LEaf spot of apple. Vartous theories have been advanced to explain the cause of the laaf spot rliscase. In I 192 Stewart and Eustace ( I $) 02: 228)$ believed spray injury to be the responsible atrency. They further suswest (page 232 of same reference) that dropse of rain act as lenes's ant so cmcentrate the rays of the sun, nerheating the tissues lenenth. The belief is ultimately expressed by them that the large proportion of leaf spot in New York is due to spray injury and is not of fungouls origin. Frost has been considered the causal factor by Stone and Sinith (1no3) in 


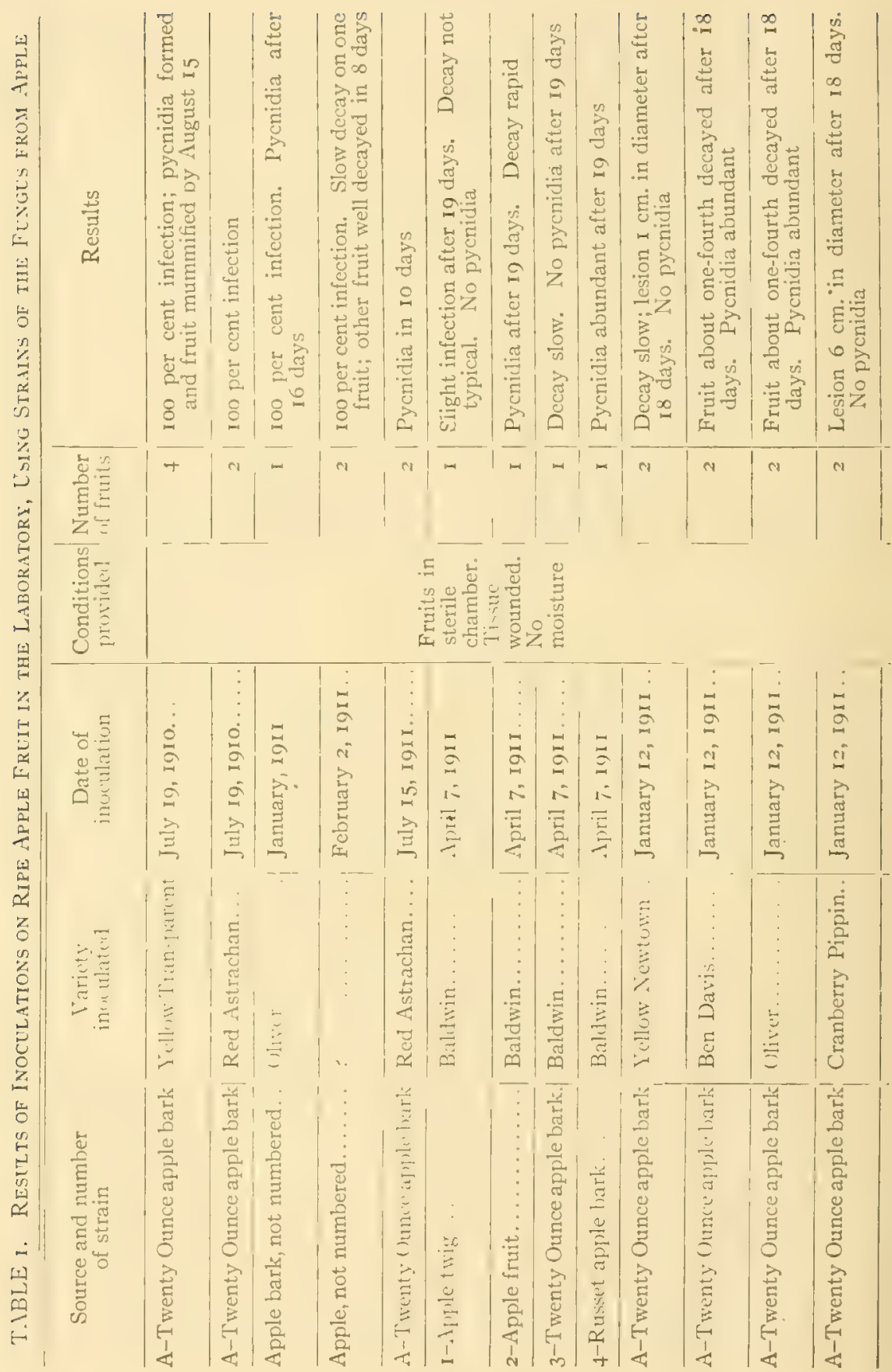


Black Rot, Leaf Spot, and Cankek of Ponaceors-Frits 8i
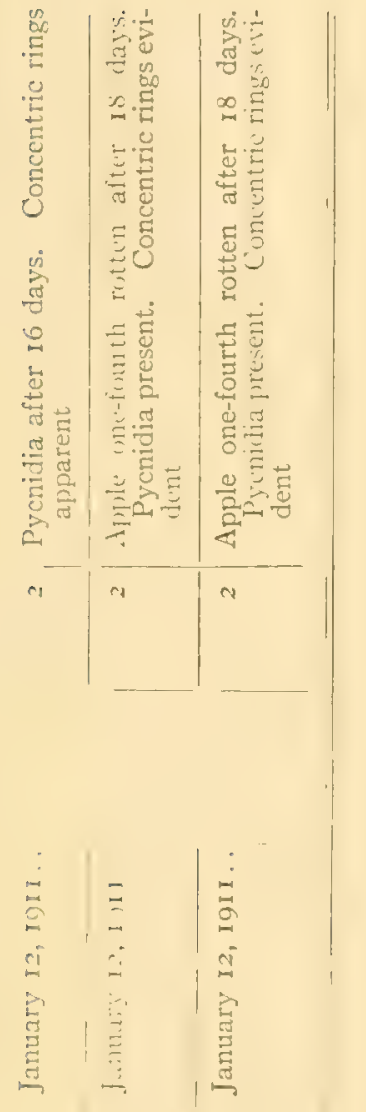


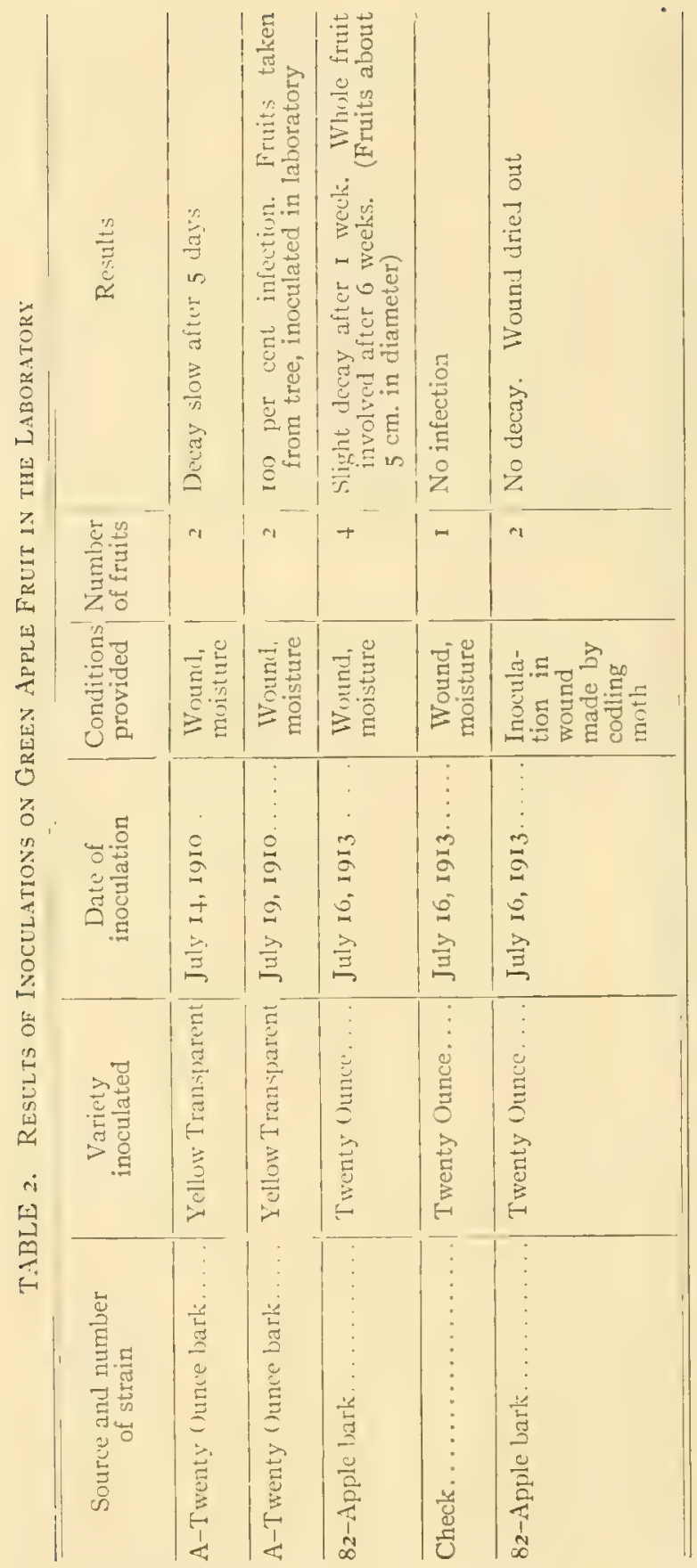


Massachusetts. They write: "No ureanism was to be found as the cause of the injury, and from the sequence of erents there could be no reasonable doubt that the frost was the destructive agency."

The fungus therry was probalily frrit lavorul by Alwond (rSo2:50), who attributed borm spot to Philhstictz frimu. This organism has been regarded as the cansal agent hy serertit wher writers - Kinney

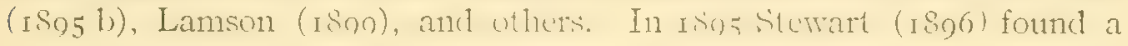

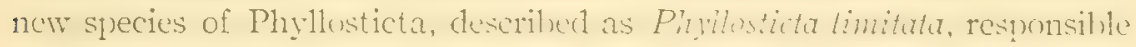
for an epliphytotic of leaf spot an Lomer Island. In ino 7 the fungus Phyllosticta pirina Sace. Was trancferted to the denus Coniothyrium by

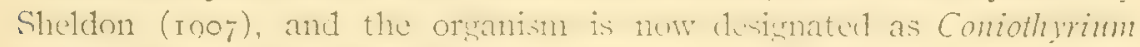

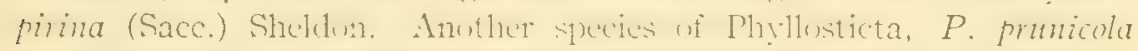
Sace, is listed by Tulu ut and smith ${ }^{7}$ as the cause of slutting of leaves of apple, plum, cherry, and apricot.

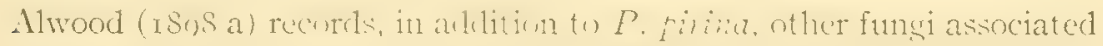
with the leaf spot, including Hentersoniu Mali and Sphuterosis Malormm. This is the earliest reered that the writer has seen of the occurrence of the last-named fungus on leaves of aprle, althrush Clinton (ino2, and InO4:20\$) reports it a: the commmon cance of leaf spot in Illinois and Connecticut in later years. The que tion of it.s relationship to the leaf spot disease, as well as that of uther funci, was subsequently studier by various pathologists.

Sontt and (Ouantance $($ ino;) state that sereral different fungri, most

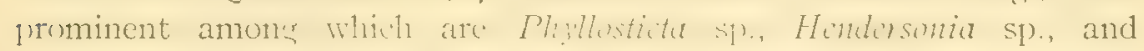
Sphacropsis Malomm, are coniected with spot ind nay be responsible for the injury in some cases, yet iley are lint clear as to which are the real parasites. The following y.u. the -ul juct was investisated by Hartley, I. M. Lewis, and Sout and Rurer. IIartley (Inosh h), in examining leaf spots of apple from the West Virsinia Acrionltural Experiment Station.

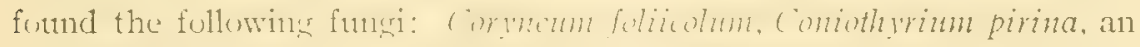
undetermined specics if the Tulxerularian, Splatropsis Malorum, Mono-

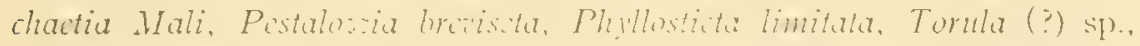

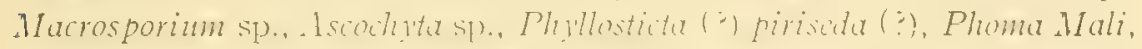
Septoria piricola (引), Metuspluterid s1\%, and an uncletermined species of Leptostromaceae. He expreseses the opinion that 1 robably Cormem folicolum was fomerly reported as a Henclersmia. The fact that the parasitism of (conioth winm pirmu was questioned iny Stewart and Eustace (1902:22S) led Hartley to insestisate the patherencity of this species. He found that it would not affect healthy tisste, but that on the other hand, when wounds stuch as scaldins, abrasion of epidermis, or punctures

7 Tubeuf, K. F. von, and Smith, W. G. Diseases of plants induced by cryptogamic parasites, page 463. I 897 . 
with hot and cold needles, were made in the tissue, the fungus in most cases grew and fruited. He concludes that (', pirinu is a facultative, or wound, parasite only, and further that its ability to cause leal siot in orchard trees to any extent remains to be demonstrated. In his opinion Coryncum foliicolum is less parasitic in the ficht than Coniothyrimm pirina.

I. M. Lewis ( $1908: 36 \%$ ) writes as follows regarding the leaf spot situation in New Hampshire: "Believing that the exact relation of all the fungi associated with the spots had not been thoroughly tested, an investigation was begun during the past summer to determine, if pessilile, the cause of the discase as it occurs in this State, and means of control by various spray mixtures." He states further (pace 3 th of ame refetence) that on isolation it was found that the funci prectominating were (onio-

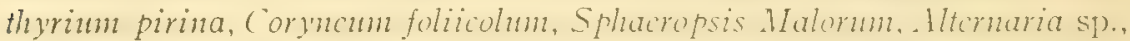
and one of the Tuberculariae. To Hartley's iotal list of fungi associated with apple leaf spots. C. E. Lewis (I) I 2:5I) adels (ludesporium horharm (Pers.) Link and Domatium pullulans De Bary, while Browks and De. Ieritt (IgIz:ISz) report the isolation of a Fusarium. The first series of experiments made by I. M. Lewis ( rgoS), (m Aurust I showerl that many inoculations did not result in infections; from this Lewis reasons that "the period at which the leaf is naturally infected is earlier in the sinring and summer." This view is upheld hy C. E. I. ewis ( In I 2:55), who concludes that the older leaves are not so susceptible to infection as are yound leaves; the work of Brooks and De.MIritt (I0) I : I (0) , however, in which they conclude that infection may occur until the last of Aurust, indicates that the question of biologic races was a factor crerlunlied by both I. M. Lewis and C. E. Lewis. As regarls the senceral conclusions of I. M. Lewis's work it may be further quoted (Igo8):

As a result of this season's inculation experiments it is imprsilule to ofter more than negative results as to the cause of the spots. I am of the opinion, however, that the fungus Sphaeropsis malormm which is linown to caune canlier of alyphe limbs and is an active parasite, will he found to he the primary (anse of apjle lewi spot. This supposition must, however, be suphorted hy direct experiment lufore it can he definitely affirmed for the spots considered in this investigation.

The same year the results of further investications by Scott and Rorer (19o8) were published, in which a definite conclusion was reached. They state (page 49 of reference cited): "It was found that Sphacropsis malortm, contrary to the general belief, is the cause of the discase." Regarding the associated species they conclude (jage 52 of same references):

Coniothyrium pirina (Sace.) Sheldon, atthough it necurs alumdantly on apple leafspots, appears to have nothing to do with their formation.

The several other fungi that were tested, such as Hendersonia sp., Coryneum sp., Pestalozsia sp., and Alternaria sp., proved to he non-parasitic in these experiments and probably occur on leaf spots only as saprophytes. 
The work of Soutt and Rorer is practically confirmed by C. E. Lewis (inom). Aiter makins sureal inwculation experiments the latter writes (I9I2: 55), in agreement with Hartley (I908 b), as follows:

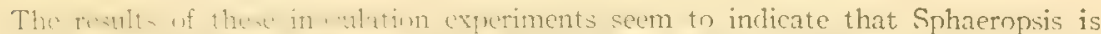

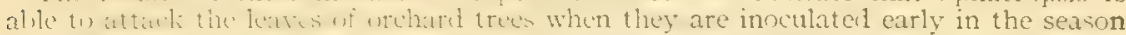

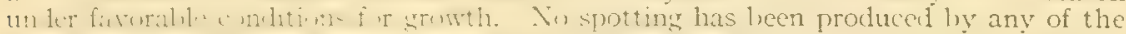

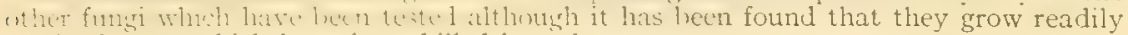
on dead spots which have been killed by other causes.

The investintinns if $\mathrm{L}$. M. Lewis beran in roos and were continued by Brooks and De..Teritt in roor). As Brooks and De.Meritt state (Ig12: I $S_{3}$ ), the summer": work was not conclusire. Later cultural work revealed to then sreat variation in the nature of grorth of different strains of the funcrus, and al:o in the time recuired for spore production. It has been mentionerl elsewhere pace osit that these authors found morphological strain': This disowery led them to investigate the correlation between the morpholemical and hiolocical variations of these forms. Their final conclusion (page reo wi reference cited) is: "Sereral strains of Sphacropsis

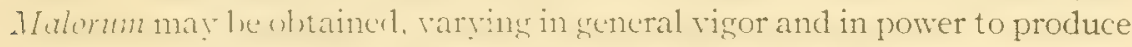
distaserl conditions. The large-sponer form, with single-loculed, ostiolate Iyenirlia is larsely responsible for the production of leaf spot."

The writer performul incuculation experiments in an attempt to produce anple leat spot luring the summers of Igro to roI, inclusive. In the (xiperiments of Io Io the leaves of mature trees were inoculated in the following manner: Pychitia were removed from pure culture and the spores liberated 1,y crushing the fruiting bodies in a watch glass containing water. The enntents of the watch slass were removed to an atomizer and the siners were simayel on lunth surfaces of the leaves. In some cases the leaves were previously womkled with a needle, in others they were left miningurel. Data rentring the source of the fungus, the variety and age of the tree whose leaves were insculaterd, the date of inoculation, the number of learse innculated, and the results. for in ro to in 3 , are given in table 3 . It is w he noterl that no moist chamber was provided in any of the (xperimats af Ioro. In I I I a series of inoculations made on May 27 resultert in infection where wounds and moisture were provided. The methul of worl: lecre was the same as in in o, except for the provision of a monst chamber. This consisted of a lamp chimney, into which the inoculated leares: were inserted and the ends of which were closed with damp cotton. The series of inoculations performed in July, rgro, and in Aurnst irj I, shumld be compared. In neither case was a moist chamber wete and the results were newative. In the experiments of 1912 and ig 3 no spretting of the foliage was blataned by artificial inoculations. The writer has nu (xplanation (1) offer. The explanation offered by Brooks 


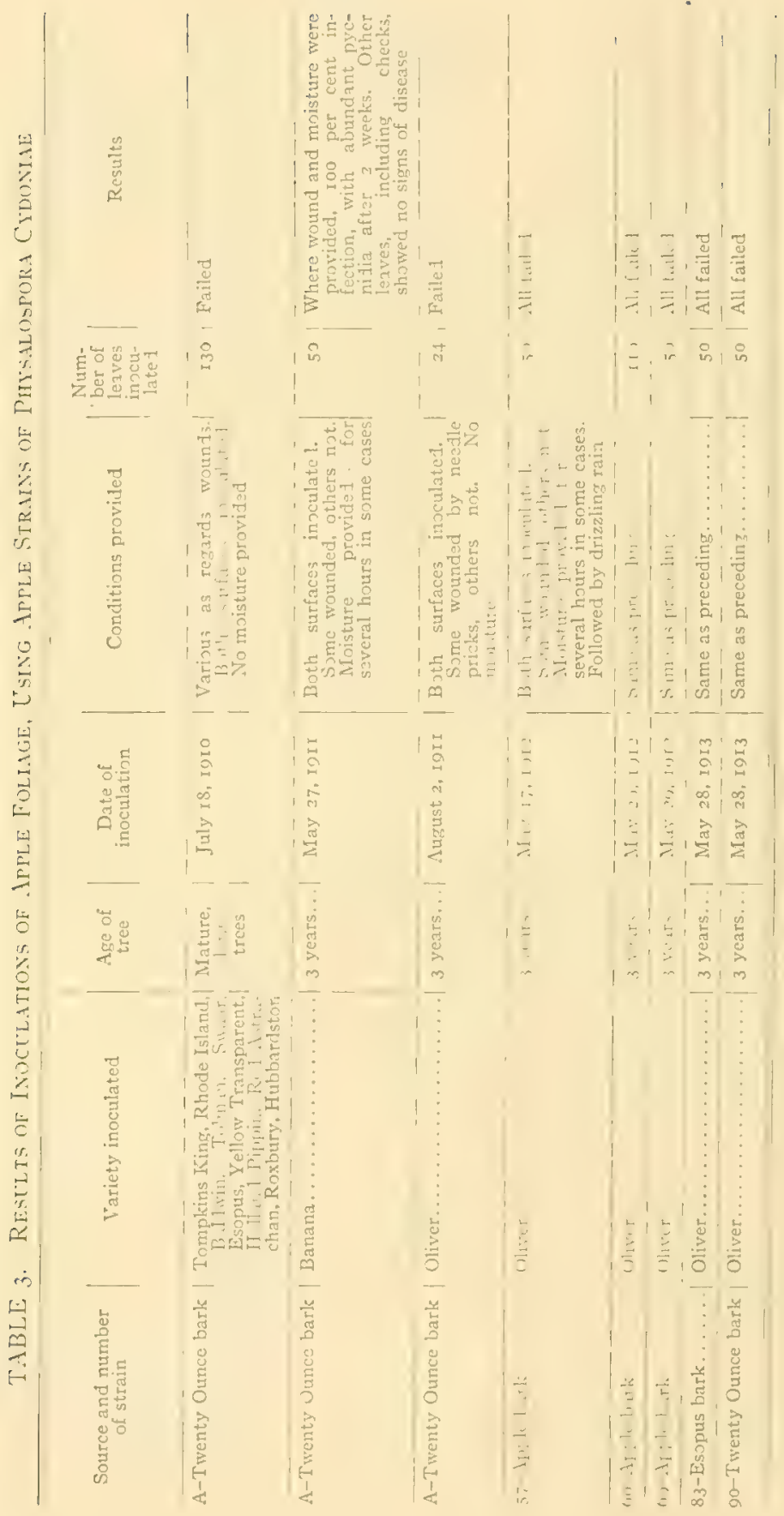


and Duleritt (ing2) for the leaf spot problem in New Hampshire is apparently not applicalle under western New Yorli conditions, since a variety of morphological forms was used in the inoculation worts. The results obtained indicate that there is no correlation between morphological and hiological characters with respect to patherenicity.

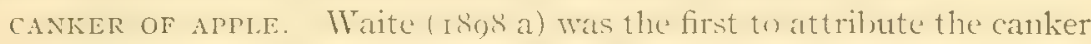
to a funcrusts paracite; he sugrested that Sichoply yllum commune Fr. was

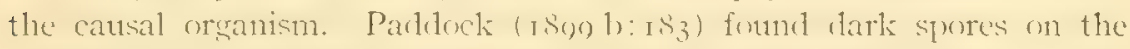
canliers, but supposed they belonged to some saprophytic form. However, he crew this urganism, as well as Sithophyllnm commmne, on artificial media, and marte pure culture inceulations in the following manner: A small opening was made in the hark hy means of a sterilized knife, and a small quantity of material from bean stem cultures was inserted between the word and the bark. The incision was covered with morist filter paper and hept moist for thirty-six hours. All the ineculations made in 1898 with the dark-spored fungus on apple trees were sucessful; other fungi failed and the wounds sone healed. Paddocls's conclusions are summarized in the following words (page rist of same ruference): "These experiments showerl conclusively that the dark-spored fungrus can penetrate living apple-tree bark under certain comlitions and produce a canlicered condition of apple-tree limbs and also inclicater that it may produce a diseased condition of pear-tree hark." Again he says (page is's of same reforence): "The result of orer fifty inoculations made from cultures that were obtained from cankered apple tree linuls prove that the apple-tree canker of New Fork apple orchards is caused hy a fungus of the gemus Sphneropsis." Orere one thontsand inoculations were made by him in I Son (pages 200-20 I of same ruferene(e) and unly a very few save negative results. IIe further asserts that the fungrus caluses canker of the quince if the material frem prure culture is inserted under the bark, whereas under other conditions the experiments were not conclusive.

Paddock's work was continued ( I000) for the purjose of confirming former results and to determine if possil)le the relationship between the species of Sphaeropsis that occur on various plants. He obtained cultures from apple fruit and apple bark, and innculated the apple tree and other plants. The results were positive, thus further proving the pathogenicity of the organism, as well ats establishing the ielentity of the fungus on fruit and bark. The conclusinns reached by Parkoch are essentially confirmed by C. E. Lewis (I909: I88-I89) and by McCready (I9Io).

The writer ( 10 I $3: 20,3$ ) has summarized the results of earlice inoculation work as follows:

During the past summer [19I3i several indulitions have been marle with cultures

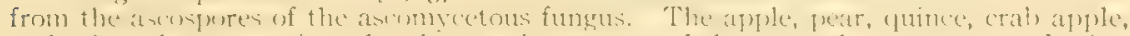

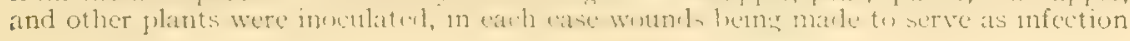


courts. Three varieties of apples, mamely Twenty Oun'ce, Bullwin, and Chenango Strawherry, were inoculated hetweer May 20 anil July I6, I?I3. Elever sets of experiments involving about seventy incisions wre mide, all of which give pustive infections, the checks remaining healthy.

The above quotation concerns the ascomycetous funcus from apple. A morphologically similar organism on Hamamelis sirginana did not produce infection, as is seen from the following statement (Hesler. 1013:293): "Alout twenty-five different innculations were made lwith the ascomycete from $I I$. irginianal on all the plants mentioned above but no infections occurred."

The writer has carricl on inoulation experiments during the past four years, both in the greenhonese and in the field, the must of the worts being directed toward the infection of loark tissues. The methords employed have already been describer (1rage $7(3)$. The results discussed at this point concern only experiments in which apple strains of the fungus (Physalospora (juloniac Amand I SFlacropsis Malomm Berli.]) were used on apple itself. The more inpurtant prints in this resard are shown in table 4 , indicating the source of the strain, the variety and age of the tree inoculated, the conditions under which inoculations were made, the number of inoculations, and the general results. The infection work done in the summers of 'IgIO, IgII, and IgI2 was not conclusive, but with the use of various strains mure satisfactory results were obtained in the season of I9I3.

It may be noted in table + that races of the fungtis came from different varieties of apple, isclations luing made from fruit, leaf, ancl harl. It was desired to determine if possible whether strains obvionsly living under saprophytic conditions, as these follewring winter injury and fire blight, were capable of inducing hark injury, and to determine the nature of the parasitism of certain other strains that appearesl to lue parasitic. The results on these points are conflicting and it secms that the strains are as variable in their liolugical relationships as in their morpholesical characters. A race may proluce infection on slightly wounderl bark after it has been living muler satprophytic conclitions, for example, following fire blight. Again, those struins which in nature aprear to be acting parasitically may prove to be weak parasites, producing infection only under certain conditions.

Conflicting results along this line have ratised the question of indlividual variation among varieties of the lust plant as rewards susceptibility or immunity. It is pussible that indivilual hests in the same or in different. orchards may differ in this respect. lut conclusive data are not at hand with which to answer the question.

The variable results of inculations of the apule with the apple fungus indicate that the production of infection recpuires the proper strain, a 


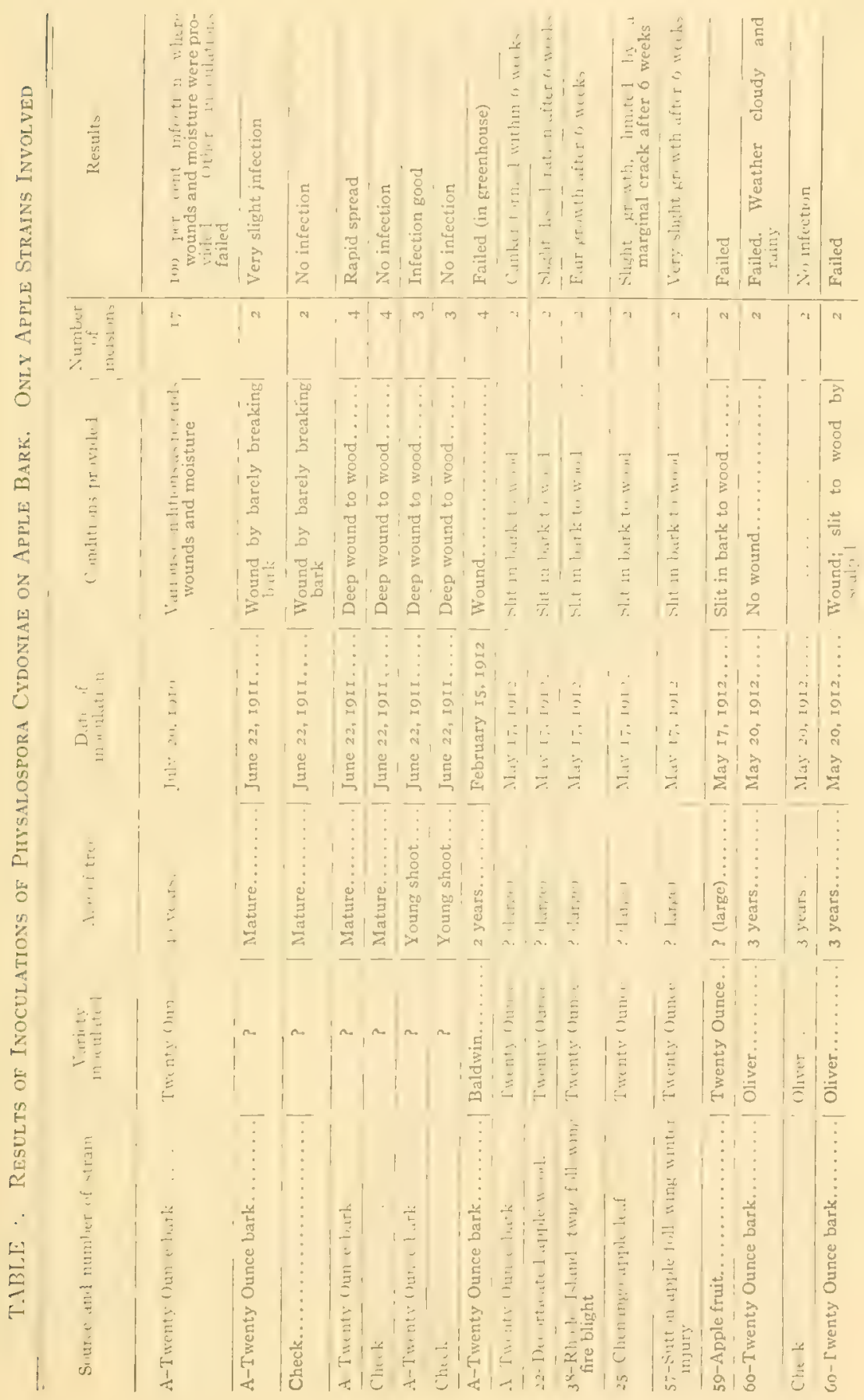




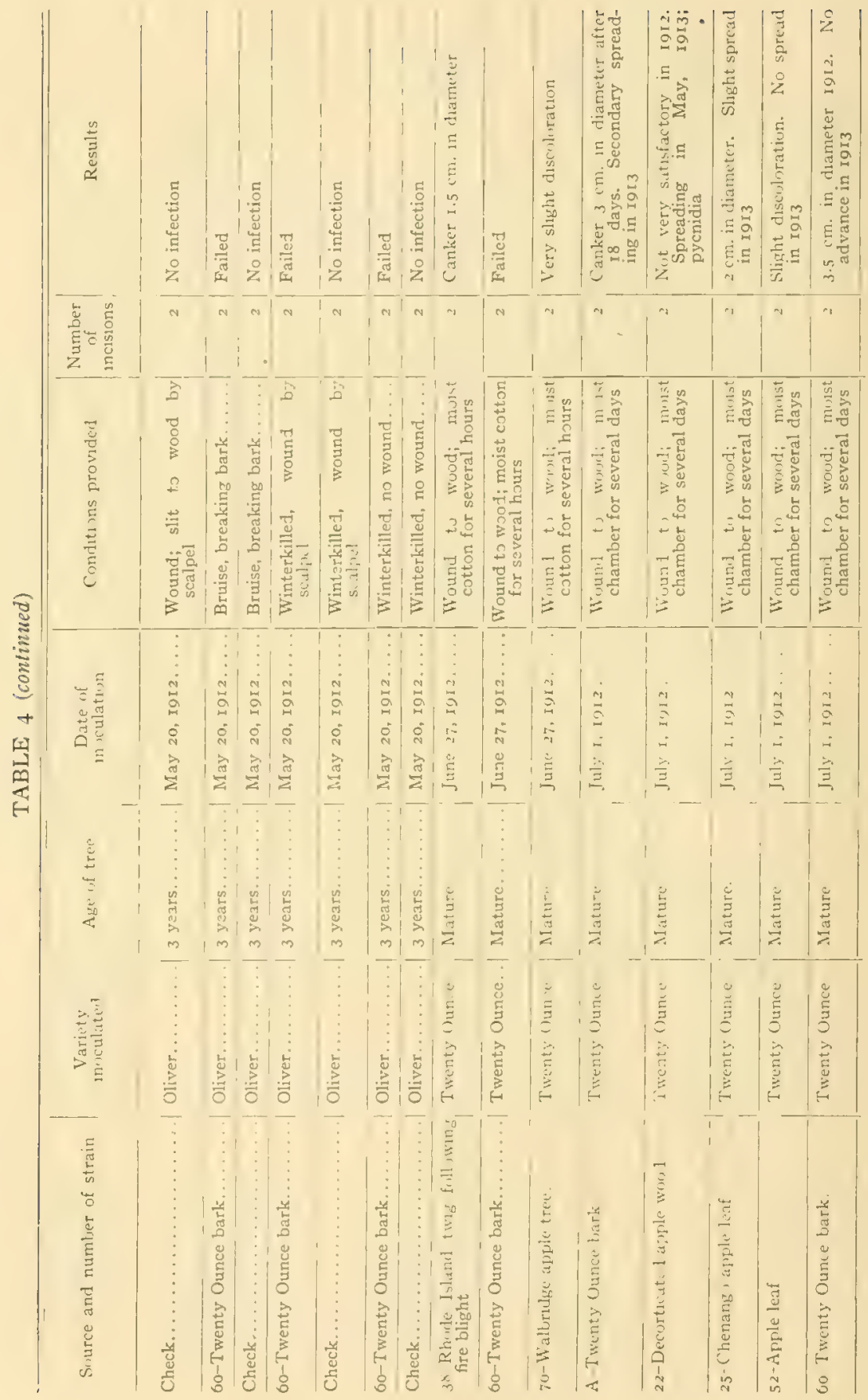


Black Rot, Leaf Spot, and Canker of Ponaceous "Frutts

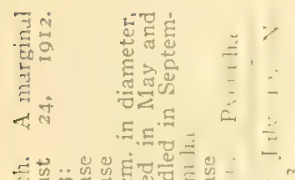

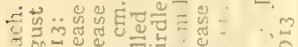
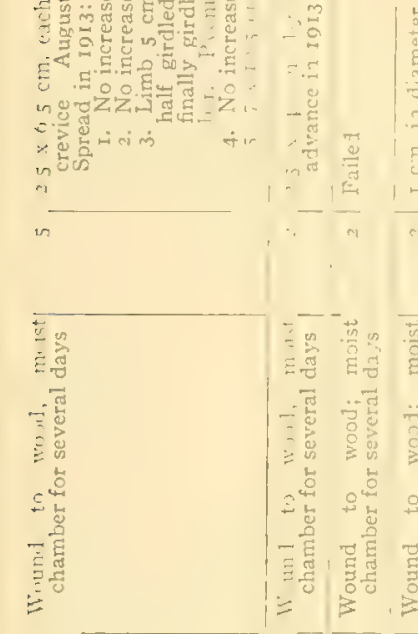


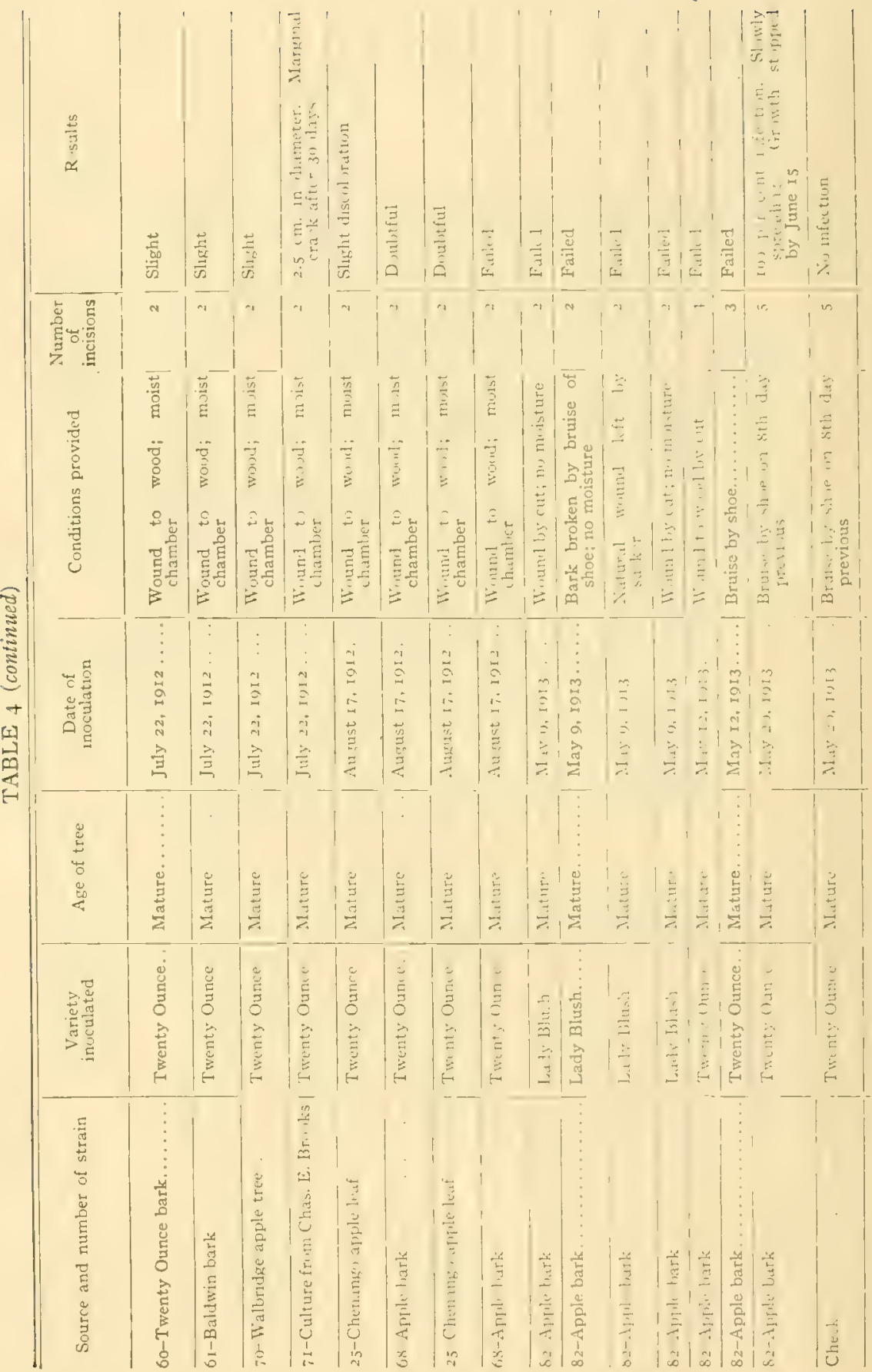


Btack Rot, Leaf Spot, and Canker of Ponaceots Freits 9.3

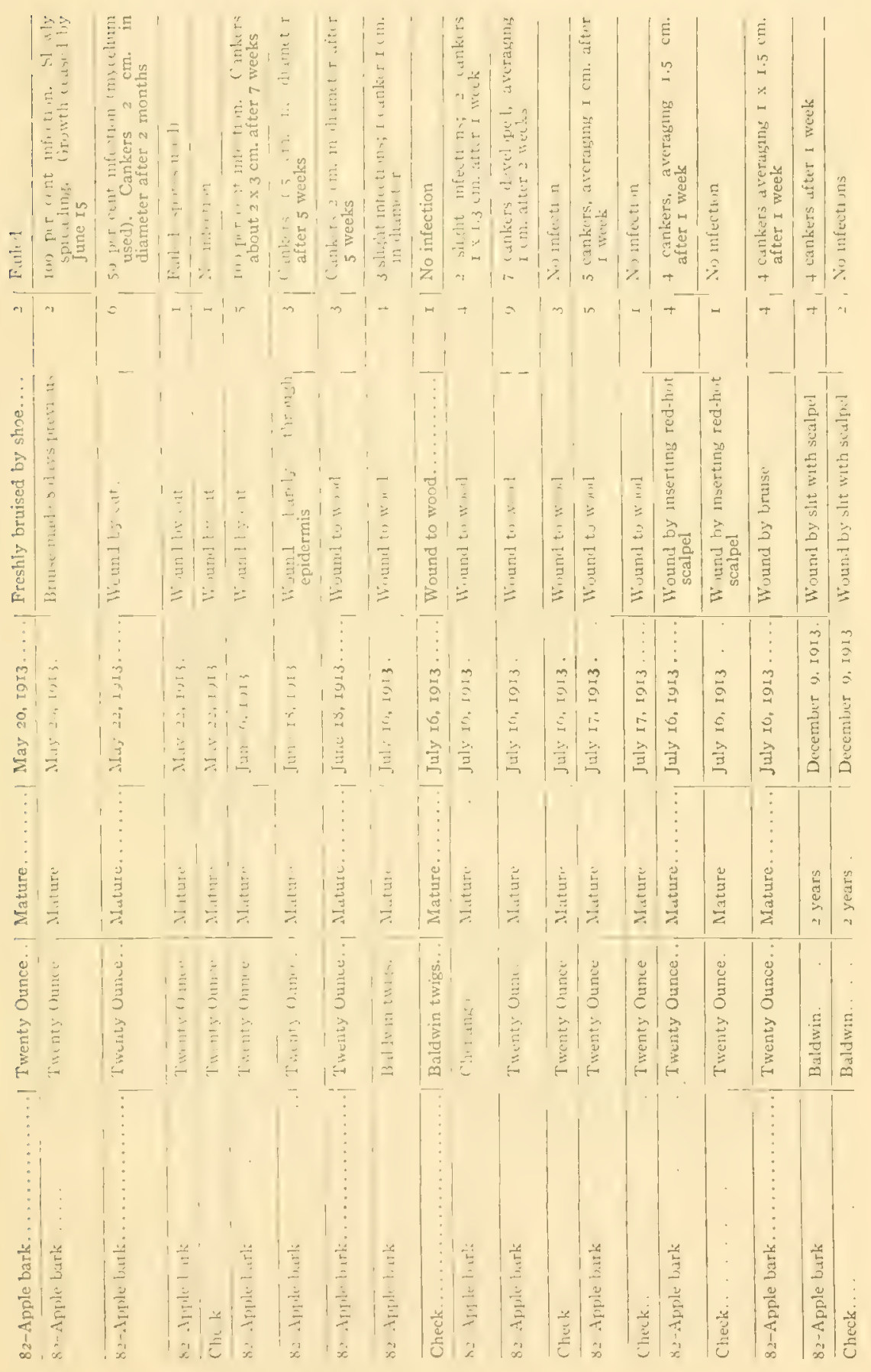




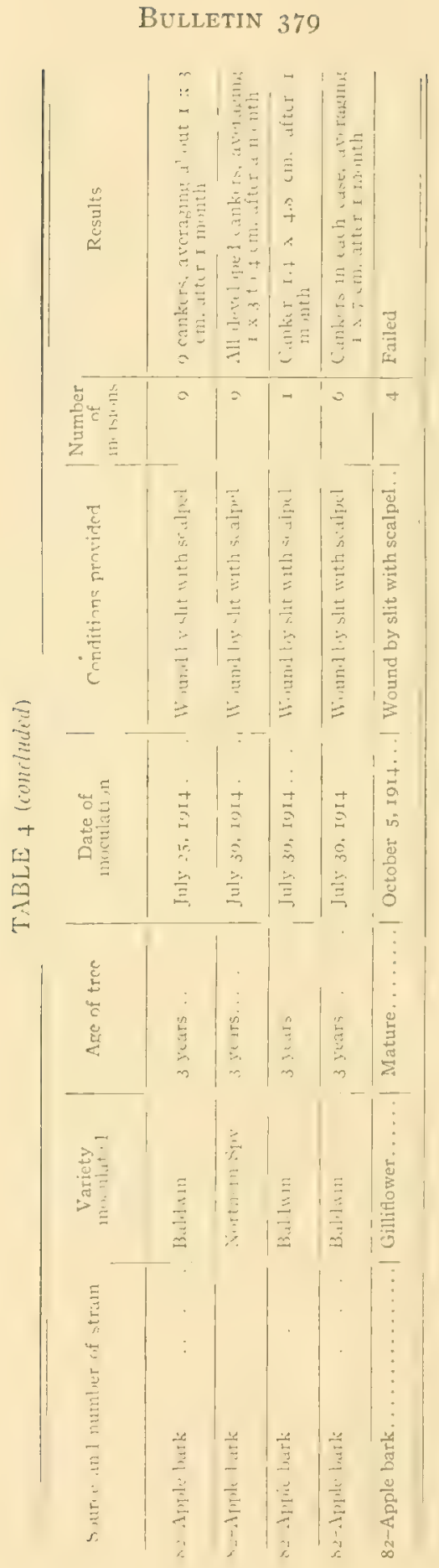


wound in which to initiate the relationship, and moisture until infection has occurred.

Associated specics. - It has been noted elsewhere that the fungus Schizoplyllum communc Fr. was suspected as being the cause of canker (Waite, I8g8 a). This apprehension was undouhtedly based on association of the fruting body of the organism with the lesions, as it is common to find this fungus fruiting on old cankered limbs. Paddock ( 8,8 a) cultured this species and after inoculating apple limbs concluded that it was not the cause of the disease.

The rôle of associated species in the production of canker on apple is taken up somerhat at length by C. E. Lewis (1912). In Maine the fungi most frequently found on dying twigs and branches of apple are Sphacropsis Malormm, Myxosporium corticolum Edgerton, Coryncum folicolum Fckl., (ytospora sp., Phoma Mali Schulz \& Sacc., and Coniothyrium pirina (Sacc.) Sheldon. Those often developing in plate cultures were: Phyllosticta limitata Peck, Dematium pullulans De Bary, cladosporim herbarmm (Pers.) Link, Alternaria sp., Macrosporimm sp)., Fusarium sp), Epicoccum sp.., and (Jloncrella cingulata (Stonem.) Sip. \& von Sch. To this list the writer adds Septoria spe., (ephalothecium roseum Cda., and Aspergillus sp. C. E. Lewis (1912:62) concludes "that Coryneum and Phoma can cause considerable injury to young trees and branches of orchard trees. Myxosporium and Cytospora do not attack healthy: branches but it seems probable that they attack weakened branches." The writer's results with the various associated fungi may be summarized by the statement that none of the species cnumerated abore made growth on apple bark.

CROSS-INOCULATIONS AND HOST RELATIONSHIPS (Plates VIII, IX, XI, XIV). The identity of the various species of Sphaeropsis on the same and on different plants has been established in certain cases. That the species on the fruit of apple is the same as that on the bark was proved by Paddock (I\$99 b, I900) several years ago, and confinned by Potebnia (ig07) more recently. A similar relationship for the fruit and foliage forms of the fungus has been proved by MIorse (1900), while Scott and Rorer (inos) have demonstrated the identity of the organism on leaves and bark. The ability of these three forms to grow interchangeably on the several organs of the apple is no longer questioned, and the results of previous investigations are essentially confirmed by the writer in tables $\mathbf{I}, 2,3$, and 4 .

The pycnidial stage of Physalospora (ydoniac Amand (Sphacropsis Malorm Berk.) has been collected by various investigators (Parddock, Arnaud, the writer, and others) on the following plants: apple (Pyrus malus L.), apricot (Prunus armeniaca L.), alder (Almus glutinosa Gaertn.), 


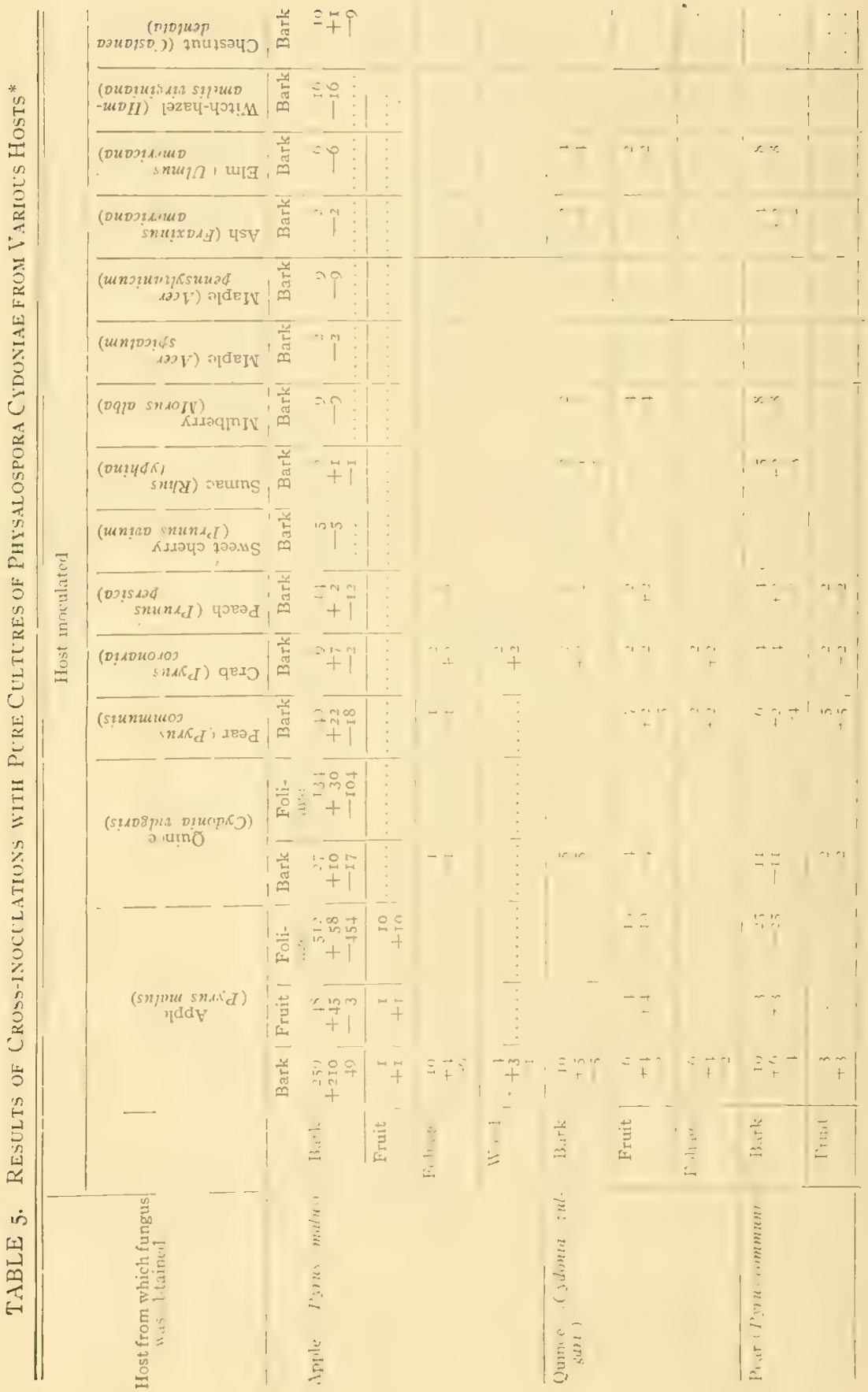




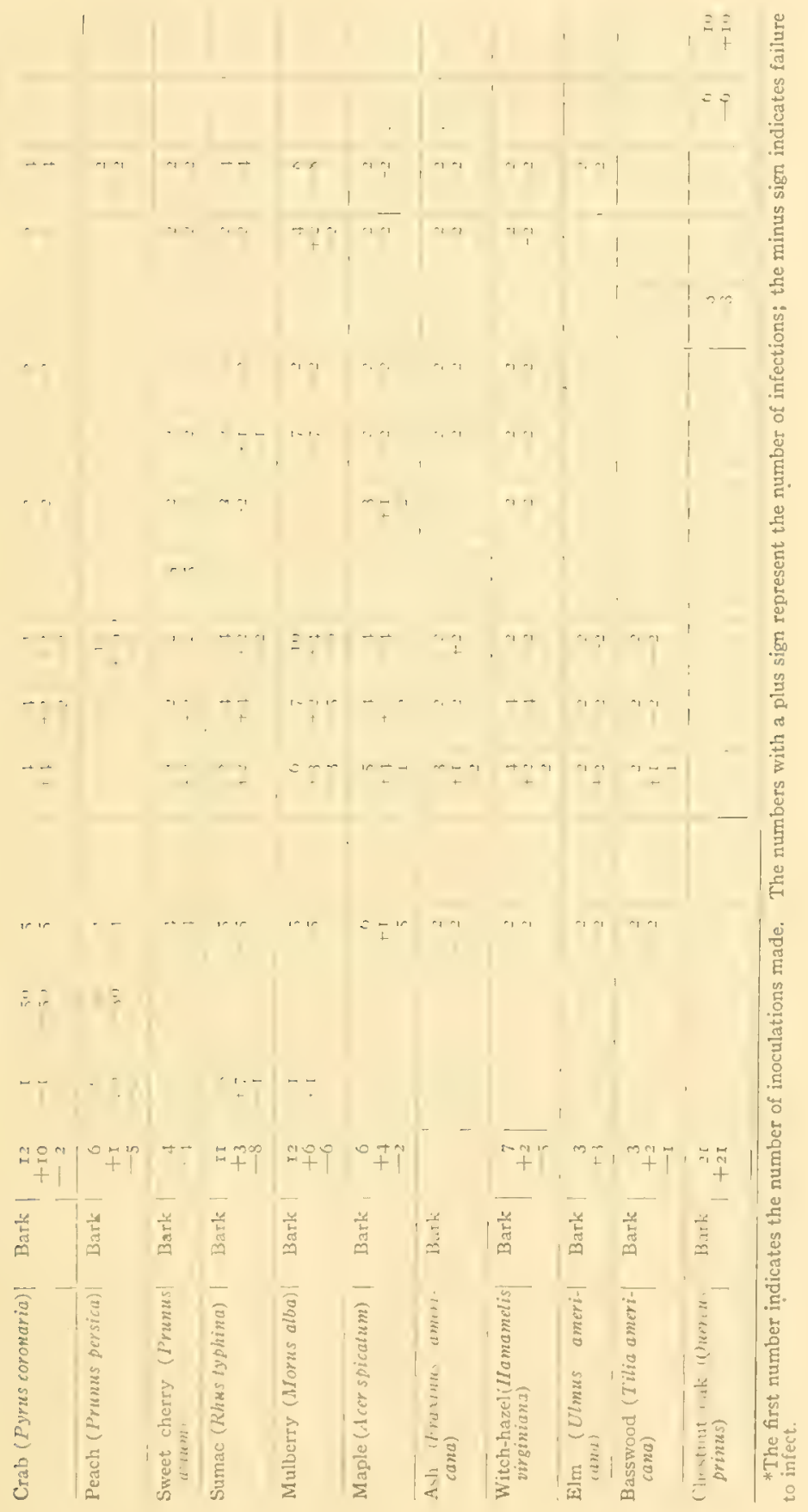


ash (Fraximus americana L.), basswond (Tilia americana L.), bitterswect (Ciclastrus seandens L.), box elder (Acer negundo L.), cherry (Prunus arium L., P. pennsyliania L., P. virginiana L.), cherry laurel (Prumus lauro-ccrasus L.), crab (Pyrus coronaria L.), currant (Ribes sp).), drongood (Cornus stolonifera Michx., C. sanguinea L.), elder (Sambunous canadensis L.), clm ( C’lmus anuricana L.), figr (Ficus carica L.), grape (T'itis sp.), hawthorn (Cratuegus orycantha L.), hop hombeam (Ostrya airginica [Mill.] K. Kexh), lilac (Syringa zulgaris L.), maple (Acer sacharinum L.), mulberry (M Iorus alba L.), cak (Cucrus alba L., Q. prinus L.), osage orange (1Maclura pomifera [Raf.] Schneider), peach (Prumus persica [L.] Stokes), pear (Pyrus communis L.), persimmon (Diospyros virginiana L.), pine (Pinus strobus L.), plum (Prunus domestica L., P. triflora Roxby.), quince (Cylonia aulgaris Pers.), rose (Rosa canina L., Kosel sp.), rose of sharon (Hibiscus syriacus L.), spricebush (Bensoin aestivali [L.] Nees's), sumac (Rhus typhina L., R. glahra L.), sycamore (Platanus orientalis L.), witch-hazel (Hamumclis virginiana L.). Where fresh material was availal le the writer culturer the fungus from all these plants except three - (dugrvood, lilac, and rose of sharon, which have just been collected - and these cultures were used in all cross-inoculation experiments. The source of the cultures used, the plants inoculated, and the results, are shown in table 5. The methods used were similar to thuse described in connection with the inoctlation experiments on apple fruit (page $; 0)$. In some of the earlier experiments a moist chamber was used consisting of a petri-dish lid, the inner margin of which was lined with (amp entton. Later the glass licl was eliminated and a cotton cap, made by rolling a strip of cotton about the finger, was employed. Moisture was provided at the time of ineculation and was added daily for several (usually from three to seven) days subsequently.

The restults of cross-inoculations were not conclusive, particularly in cases in which the fungus failed to derelop. Failure to produce infection may be accumted for in two ways: either the fungus was not parasitic on the plant inoculated, or conditions favorable for infection were lacking. In many cases further trials are desirable.

In nature the funeus rarely shows a parasitic tendency on wild plants with the execption of ()ucrus primus (sec Rankin, in $\mathrm{I}_{4}$ ) - but it is senerally fonnd dereloning on dead and fallen twiess; cankers have not been observed which cotld with certainty be attributed to this organism. On cultivated plants it commonly slows the same habits as it does on wild Hants, or it may derchop in healthy tissues, resulting in the formation of a canleer. Here, then, on the cultivated plants are found both saprophytic and parasitic temfencies. This phenomenon is in accordance with the commonly accepted theory that parasitism originated from sapro- 
phytism. This is what is to be expected; atud the therry is further stupported by incoulation data which show that the strains from wild plants may be indererd to infect cultivater p)lants. The reverse prexese - that is, the infection of wild plonts with strans fom either cultivated or wild fomns - has luen almust wholly mancessful in the witer's experience. This in the main confirms the work of Paddock ( 899 b, I900).

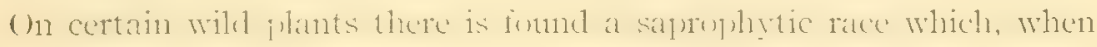

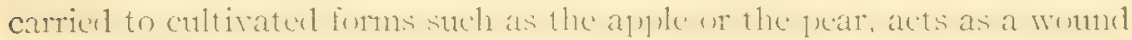
parasite. ()n cullivated plants the fungus follows lire blipht and winter

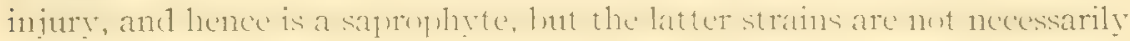

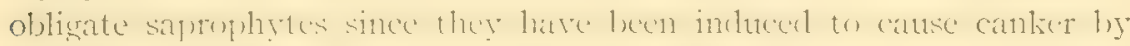

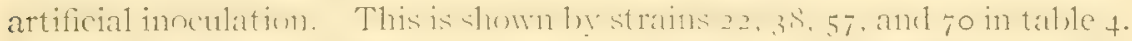

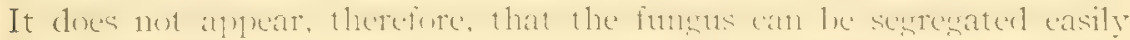

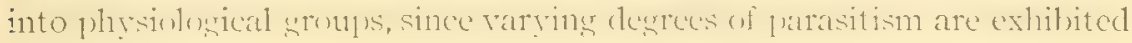
by a given race.

From the cxperinents described and talulated it is char that there is considerable rariation in the virulenee of relees, lut just lum lones a given parasitic strain will retain this mode of life is a diflicult gluest ion to atnstrer.

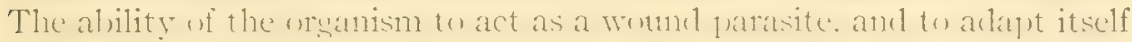
naturally to the sajprohytic nocke, males it a serions gest from the stater-

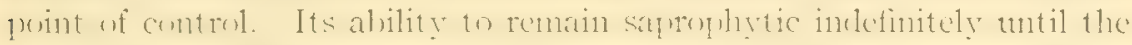
host is injurer in some may only increases the dificulty in allertating the disease.

NAMES AND SYNONYMY

The work that has been done on cross-inoculations and on the morphulemy of sphacropsis from seretal different platnts mukes it apporent that there is one lare polymorphic spectes. It is true that many inneulations failerl, and that two given races mat differ widely in their non-

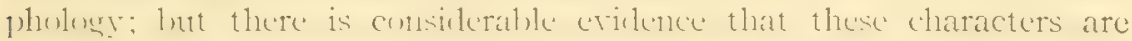
variable and are not important in taxonomic considerations.

The several fomms as they have lecte deseriberl from time to time have

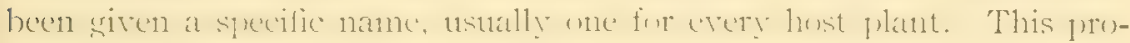
corture has resultul in the acemmulation of a latse number of specific names which conld now he dispessul of omly by the cxamination of type

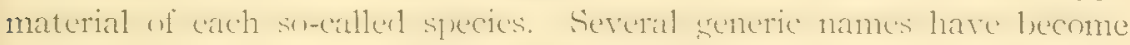
involver in the smonymy of the functs, due to the indefindte limitations

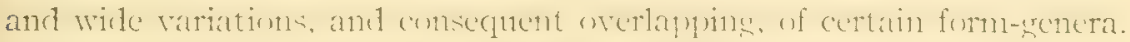

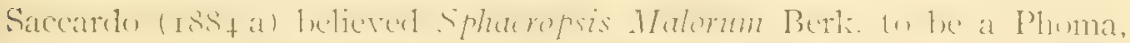

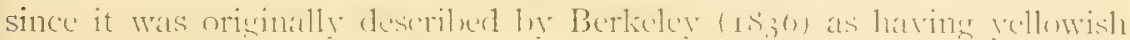

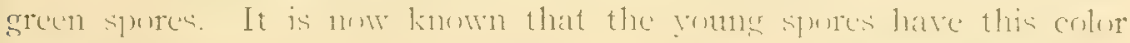
characteristically, and furthermore Dr. C. L. Shear, whollas secu Burkeley's 
type, has stated (in conversation with Dr. Donald Reddick, of Cornell University) that the organism is munuestionably identical with sphacropsis Malormm as now recornized. Subsequent to Saccardo's use of the name Phoma, this grenus was dividert into Phoma and Aiacrophoma - the former genus containing species with spores less than $15 \mu$ long, the latter containing species with spores more than $15 \mu$ long. Thus Phoma Malorm (Berk.) Sacc. was renamed lyy Berlese and Toylino (iSS6) as . Jacrophoma Malorum (Berk.) Berl. \& Vogl.

It appears that certain species of Sphacropsis have been confused with those of Diplodia. The two genera are separated on the basis of onecelled spores in the former and two-celled spones in the latter. But both genera fail in their chief distinction, so that mycologrists have been misled on this point. Fuckel (1800:30,3) used the name Jiplodia pseudodiplodia Fokl. in describing the fungus on branches of apple; clsewhere (page 395 of same reference) he used Diplodia Malorum Fckl.

It has been noted freviously that the pencitium sometimes approaches and even reaches the condition characteristic of the form-grems Botryodiplodia. It becomes evident that the names of certain species of this genus may stand only as synonyms of Physalespora (ydoniac Arnaud.

The origin of several of these symenyms has heen discussed in an carlier paper by the writer (ing2), to which the reader is referred. At that time it seemed desiralle to attempt the selection of the name that should, according to the rules of priority, he applied to the pycniclial stage. Recently, however, the perfect stage of the fungrus has been found, and thus the selection of a specific name from the proctidial forms is of minor importance. The generic name now becomes Physalospona, and the writer has chosen ('doniac as the specific name. The following statements bearing on this question are quoted from another paper by the writer (I9I3:295):

The froblem of selecting a speritic name is somewhat perplexing. The organism

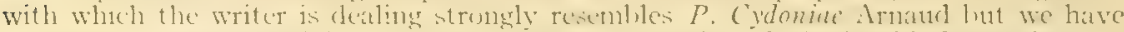
not seem his type miaterial and there remanns the gusestion of whet her his fungus has not been previously described. In this connection a few species which suggest this possibility may be noted: $P$. entaxia E. \& E., P. festucae (Lib.) Sacc. and $P$. nigropunclala Romell, the last on linsts of Pyos mulus according tos sactardo. Intil further data are at hatnel the writer i.s inclineil to aceept tentatively the name Ihysalospore cydoniae Arnaud.

Som after the above-mentioned paper appeared in print, the writer received from Arnaul a slycerin-jelly mount of his tye material. It is clear that morphologically the organism is identical with the one described by the writer (InI.3) under the same name. But the question of the specific name is still unsettled, for it is not improbable, as stated above, that the organism has been previnusly described under some other specific name. This problem, as in the casc of the sereral pycnidial 
forns, wotid involve the stury of type material, which as yet has not

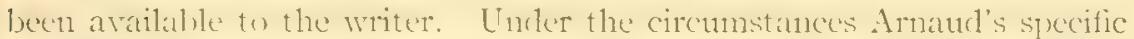
nane will te tetained tentatively hy the writer. The following is a partial list of speries which are ennermed in the synonymy of the fungus; citations to literature are also given:

Physalospora Cydoniae Arnitud. Ecole Nat. d'igr. Muntgellier. Anil. I2 7 . I1) I 2 .

Sphaeria sumachi Schw. Amer. Phil. Soc. Trans. n. S. 4:205. I 834.

Sphaeria rhuina Schw. Amer. Phil. Soc. Trans. n. S. 4:218. 1834.

Sphaeria pomorum Schw. Amer. Phil. Soc. Trans. n. S. 4:219. I834.

Sphaeria Malorum Berk. English Flora 5:257-258. 1836 .

Diplodia pseudodiplodia Fckl. Symbolae Mycologicae, p. 393. I 869.

Diplodia Malorum Fckl. Symbolae Mycologicae, p. 395. I869.

Sphaeropsis Cydoniae C. \& E. Grevillea 6:84. 1878 .

Sphaeropsis Malorwm Peck. Sylloge Fungorum 3:294. I88.4.

Several years awn Ellis ( s sio) studierl the variahility of liotryospharia

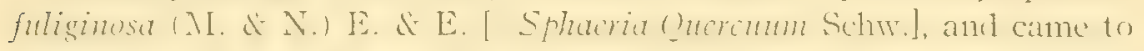
the conclusion that this species really includerl at least eighteen so-colled species. Ammor these may be noterl, using lills's nomenclature, splacria

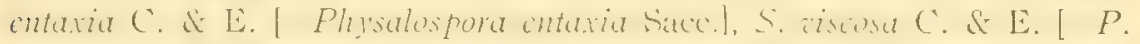

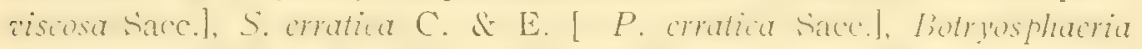
pustulalu sace, and whers. Ellis fonted wric variation with respect to stromatic formation. Sometimes the peritheciat were seattererl and distinct, and abrint they were confluent and uniterl in a stroma. Comsicler-

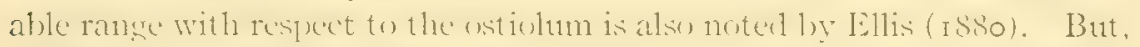

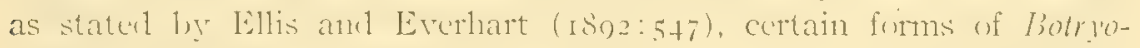
spluaria fuliginose those lackins a stroma - are removed to the sernus

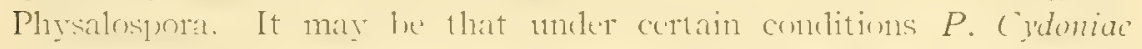
develops a stroma, hut such a tendency has not been obscrved; for this reason the generic name Physalospora is selected.

\section{LIFE HISTORY STUDIES}

The mature morphological structures of the funcus have been describer,

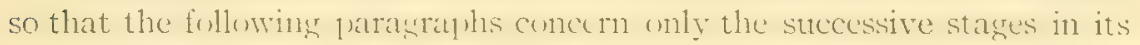
develoument: where and in what condition the urganism hibernates, the manner in which it is disieminated, its entrance and effects on the plants

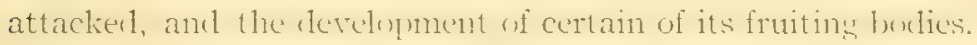

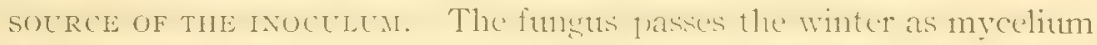

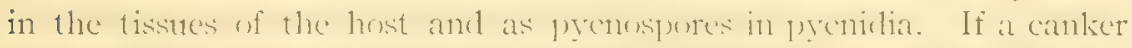
is examined in the spring when sroweth is resumed for the host plant, the maresin of the old lesion may show discestoration. The writer has frequently planted bits of the bark from the erlese of a canlere in agar plates, pure cultures resultiner. This is eridence of the resumption of growth of the mycelium in the old lesiun. It is stated by Cacsar ( I909) 
that as a rule the fungus does not die out but continues to extend in every direction year after year, finally grirdling the limb. In this connection Paddock $(1890)$ b: $1 \$ 0)$ ) writes as follows: "In some instances the mycelium apprently lives over winter and continues its growth the following spring. The formation of the largest canlices can scarcely be explained in any cother way." He adds, howerer, that "in all of the

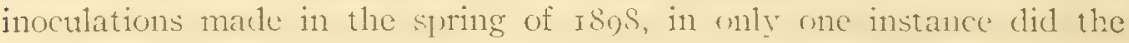
resulting canker enlarge any during the present season."

The writer's experience in this regard is smewhat similar, although more cankers have cularged the second year than is intimated 1:y Paddock. On this point there alpears to be a difference in wreherds. In wne orchard the author counted forty cankers on three trecs on May 20, igrz. All were formed at least one year previously, lut only one showed advancement at the margin on this date. In other urchards a majority of the cankers were cmlaring. The vitality of the trees doe's not secm to explain the difference displayed. since this quality apyeared similar in the two cases mentirned. The trees in the two orchards were of the same variety (Twenty Ounce): here the question of physiological races may throw light on the subject.

It has been sugrested that the mycelium may winter over in mummified fruit, and that in cases in which the fruit hangs on the tree the hyphe may pass into the franch supporting it Anonymous reference, ISonc, page I26). The latter conclition has not been observed by the writer. In some cases the mycelium hilemates in the mumnunifed fruit, but the passage of the hyphe down into the branch and the resulting development of a canker is questionable.

The wrowth of the mycelimm at the erlege of a lesion, as described above, dres not acconnt for new and isolated canliers. The phenomenon results nevertheless, inlirectly, in a somee of incoulum, in that fruit bodies may develop on the newly infected margin and so fumish spores which may canse other infections directly. The young cankers originate by the agency of the spores of the fungus.

It is a common thing to find, in the winter and spring. penclia bearing mature speres on mummificd fruits. These fruitine bodies may be observed also on cankers and on fallent twigs, bark, and leaves. In western New Jork canhirs and dead twigs are the most important sources of the inoculum.

The hilernation of pyenospores on the various organs of the tree is reported ly a mumber of investigators: on the lark, fallen twigs, and

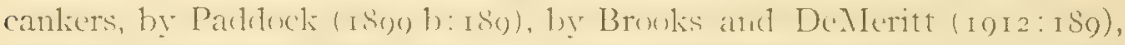
and by Scott and Roret (1nos:52); on fallen leawe's by Reed and Cooley (I9II); on the fruit, ats mummies hanging on the tree or fallen, by Scott 
and Rorer (inos:52) and hy Brocks (roor). ()ther writers have confirmed all these olservations. These sputes in winter have leen placed in room temperature, and were subsequently found ob he catpatsle of germination in tap water. There is evilenec that fycuspores may also winter over scattered ahott on the hark; they have heere fonnd in

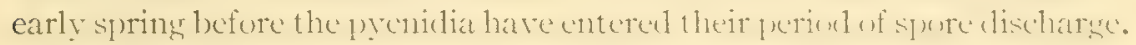

The role of the ascospurie stape in lithernation is net certain. As previously indicated, the perithecia are rare on P'yms malus in Nev Tork, and it woulis secm, therefore, that the ascosprest from this sutree are of relatively little importance in initinting infertinns. Whether this stage is common on other plants in this Sitate and important as a source of inoculum, are matters remaining to be investigated.

METHOD OF SPORE DISHAR(iE. The manner in which the prenospores escape from the pyenidium has not bern fully oleserilnet. so far as the writer knows. Berlicley ( 1836$)$ makes mention of 1 he prexcess as follows: "When ary the ostiolum is frespuently "rowner with a short minute tondril oozing out from the peritheciume." Halstex (rinz) writes: "The ripe spores . . . . form long, slender coils as they are pushed out of the small hole in the shin." similat descriptions of the process are given by Clinton (I902) and by Evans (I9IO).

If a bit of bark or of fruit bearing pyonilia is placet under mosist comditions, in a few hours dark masies of spores in the fomm of a coril may he secu (Plate xirt, 4). In one expreriment the folleming metes were taken:

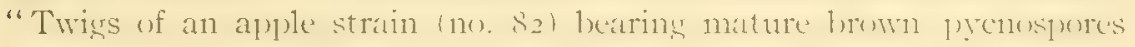
were placed in a moist chamber on May 20, I9I3, at $3 \mathrm{p} . \mathrm{m}$. By noon

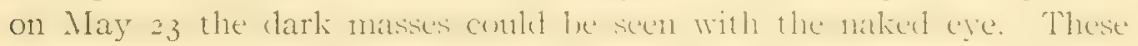
masses measure about 200 to $250 \mu$ by 400 to $450 \mu$." At this time it was observed that the masses stood out from the surface of the bark nearly five millineters. They were rery easily remered by a needle

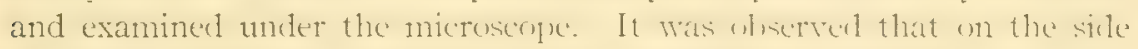
of the mass nearest the hark several spores had gemminated, and the resulting hyphes had raised the mass away from the surface of the bats. A drop of water was adrled to one mass, which behavel as follows: In

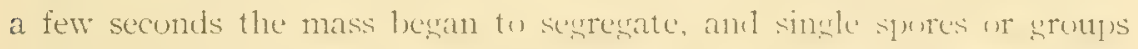
of a few moved very equickly, with a darting motion, from the mass. They were at first thrown thromsh the drop of water ats far as is $\mu$ and they then moved slowly away. After fort y-fiveminutes the spores haul scattered

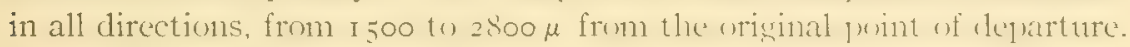
The coil in some cases containerl alunte i 500 matture simeres and in some experiments proved to be at least one millimeder in lensth. It has heen estimated by the writer that there may be as many ats a so prenticlia on a square centimeter of the surfitce of an apple fruit: this woukd fumish 
a1)roximately 225,000 spores for the given unit area, or $1,+06,250$ spores per square inch of apple surface.

As stated in the notes quoted above, the spore coils were found in the bark three days after moisture was supplied. But this does not nean that all this time was involved in the process of escape. The prenidia were found to be closed at first and considerable time must have leeen consumed in their opening. In other experiments as long a period as five days was necessary to effect the opening in some cases. The time that actually intervenes between almission of moisture to the sinore mass within the pycnidium and the coiling of the spores is neglicrit)e. Pycnidia have been removed from dry bark in the summer, placed on dry slides, and observed with the microscone. If a drop of water is then applied, the spores will ooze out immediately provided the ustiole is open. Their fate after coiling seems to depend on the amount of moisture present. If a beating rain is falling, undoubtedly the spores are carricd ly the spattering drops toward the ground and perchance lodge on the folliage or on the branches. In case of a dew, unquestionably the coil behares as described above; that is, some of the spores on the lower side of the mass germinate, the resulting weft of germ tubes raising the spores from the bark, when they may be lifted by the wind. Again, if the mass encounters a drop of water the gelatinus material quickly expands and the spores are scattered throughout the drop. It is conccivable that the drop may be carried by the wind for a short distance at least.

TIME OF SPORE DISCHARge. The time of the year when spores are disseminated may be approximated by noting the date of the first apjerarance of the diseased spots, and by kicping careful watch of the behavior of the pycnidia in the field. It is believed by I. M. Lewis ( Inos) that the period when foliage is naturally infected is early in the spring and summer. The same opinion is expressed by Brooks (rgoo), who states that the indications are that leaf infection ceases in June. Later, howerer, Broks

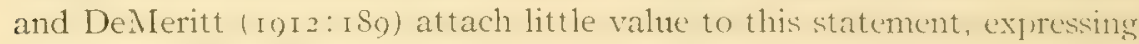
the opinion that the nature of the fungus was a factor overlooked hy previous investigators and that weather conditions may play a part in determination of the time of infection.

Paddock ( 1809 b: I 89 ) states that many spores remain in pycnidia until the following sjring, when they are disseminated. W Wolf (into) has made a study of the prevalence of fungus spores in orchards by exposing anar plates, and his conclusions are expressed as follows (pare 202 of reference cited): "At no time during the period in which exposures were made (September to May, inclusive) were riable spores of Sphatropsis malorum present in the atmosphere of the orchard." Mc(ready (I010) reports mature spores as being disseminated from canliers as carly as the first 
week in April, and states that at the same time a larese number of spores rore found in the orchard on rotten apples. In Tireinia, at Blacksburs,

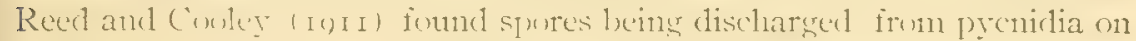
learus on Jume 25, I Io. Whether spores are liberaterl at an earlier date these anthros in not state, but it is probable that such is the case.

Frome oluserations make by the writer it serms that the date of first discharge in the spring varies with the season. Apparently the ostiole does $110 t$ (1) an at a temperature $)$ low $60^{\circ} \mathrm{F}$. ( I .5.5 C.) or in the ahsence

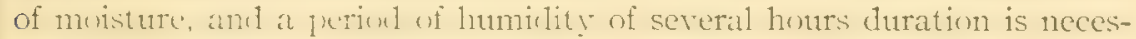
sary. The dites for spre dischare observerl at Byron. New Iork, are May I6, I9I2, and May I2 and 23, I9I3. In IgI spores were found coiling "in July I 7 , lut the process must have occurred earlier. That they continuc to be liburated throwhout the suimmer is shown ly the appearance of new infections on foliage from May nutil September 2o, I013. In IO I sereral young sputs were found on bark in the midclle of Ausust. Ripu and sreen fruit infections also show that spores are disseminated in August and September.

AGENTS OF DISSEMINATION. It is clear that the behavior of the

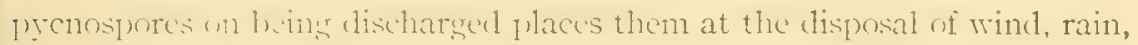
and pusibly insecti, depuling larely on the conditions of moisture. Halsted ( $189_{2}$ ) states that "the germs pass . . . . through the air or by nuans of the varions insects that risit the fruits, especially those with brolien surfaces due to partial decay." A similar opinion is expressed by

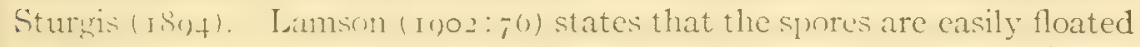
in slisht cuments of air, while Bethune ( ipog:20) and MICCready (igio) attribute dissemination to the wind.

The writer has whserver numerous cases of the disease in isolated situations. In some urchark there was abundant leaf spot but no cankers were on the tress. Here the wind probahly acted as the acrent, carrying the spores from plants ontside the orchard. That the rain washes the spores to the foliage is shom by the cone-shaped area of infections beneath cankers and diseased fruits.

Insects are no doubt arents in the dissemination of the organism. The gelatimus mature of the spores renders then sticky and they may adhere to the feet of insects. In June, InI3, the writer frund spores on the feet of the rosy apple aphis (.1plis sorli Kaltenbach), tut it is his oprinion that insects are of little importance in carrying the spores. Their rôle in making ofuenines in the fruit and bark is probably much more important.

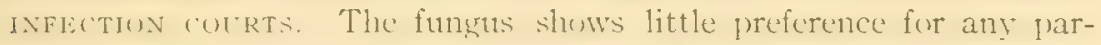
ticular tye of injury as a means of cutrance. It is not able to penetrate healthy tissuc of the lark and fruit, lut follows other funsi such as

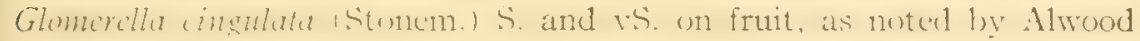


(1002:35\%). Other prints of cutrance to fruit, as listed by Burrill and Blair (ruor), are insere punctures, mechanical injuries, and the blossom end of the apple. These authers state also that the fungus secms to start withont the aid of a wound. The writer has noted many cases in which young lesions on the apjle surrounded an opening made by the codling moth (carpocapse pomonclla I..). Dulacruix $(1903 \mathrm{a}: \mathrm{I}+0)$ is disposerd to believe that in some cases certain insects are able to rupture the hark especially that of young branches. Ife observed an abundance of Epidiaspis piriolu: (I)el Cuer.) ("1.1. (nn infected areas, and is of the oprinion that these insects are concerned here. Gussow (InI) states that "apples are inferetel throush sme injury (wasps, curculin, hail, etc., etc.)."

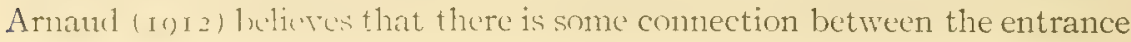
of the fungus, and a bcetle.

Observatims show alse that variotes mechanical injuries commonly serve as prints of coltrance for the fungus. Such injuries as limb and hail bruises may art in this capacity. Faurot (IOI2) states that rot occurs largely on fruts the slin of which was previously broken by spray injury and growth cracks.

Whether the healthy epidermis of the fruit is penetrated, as suggested by Burrill and Plair (InoI), is olen to question. The writer has never been able to infect ninloriken tissues of the aprple fruit. On the foliage, artificial inoculations 1y various investigators - Scott and Rorer (Igo8), Broxlis and DeNeritt (I)I2), and others - show that the fungus can penctrate healthy leaf tisus.s. The author, however, has never been succestul in protuding loaf spent without first wounding the tissue. Infections in the bark apparently oceur conly through some sort of wound. Such injurics may $1 x$ (aused l) growth cracks, as noted by Caesar (1909); by ladelers and boots, in jruning and picking; by barking by the machinery, in cultivation; by props nut carefully wrapped; by hail; by openings left by the carcless removal of water sprouts; and in other ways. Of fifteen young canlers observed ly the writer on a single tree, ten had their origin in openines left by the remoxal of suckers. The writer has nbserved cases in which the fungres had followed the rust fungus, (jomnosporangium Juniperi-ïrsiniana. Schw., on apple twigs. Scott and Rorer (1000: I1) storgest that it may follow Ihyllosticta solitaria E. \& E. on apple buds. The writer hat frepuently isolated the fungus from lesions caused by the bloteh funcus ( $P$. solituria) on apple fruits sent from Indiana. As previnusly notert, the fungus frequently follows fire blight and winter injury. Morse and Lewis ( I) Io) state that in Maine orcharits much of the discase that was callerl canker had its orionin in frost spots of InooI $\left(0^{-}\right.$, and that so far as investigated the cankers of fruit trees in Maine orchards had their origin in wounds. 


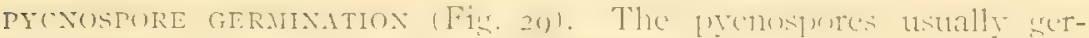
minate redelily in tap or rotiz water. The time requited for the prexes:

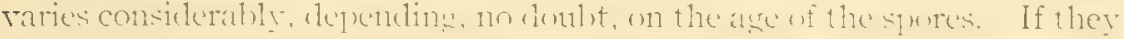

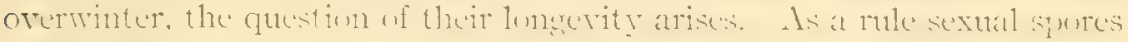
are rewartert as short-livert, hut it is not se in the casce of this fungus. Duswar \{ I gon: 3.53) says: "The spores seem te retain their vitality for a

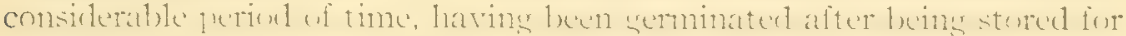

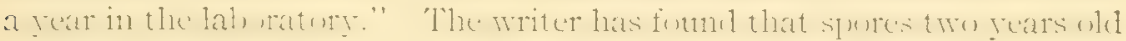

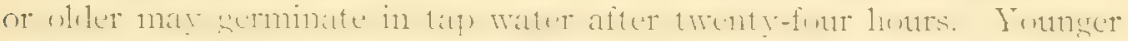

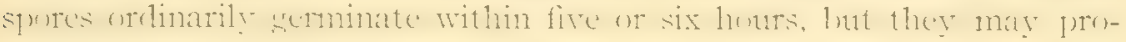

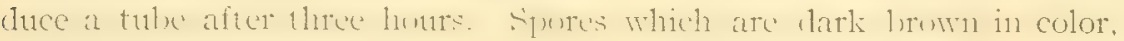
often septate, and having an older appearance, require more than twelve hours for germination.

Usually one or two tubes emerge from a spore at or near the end; germinations also occur at the side. The developing hyphre in culture occasionally form microconidia, or secondary conidia, near the growing point of a hypha; these have been mentioned by Delacroix (I)o, a: I.ju), whw states that they do not develop

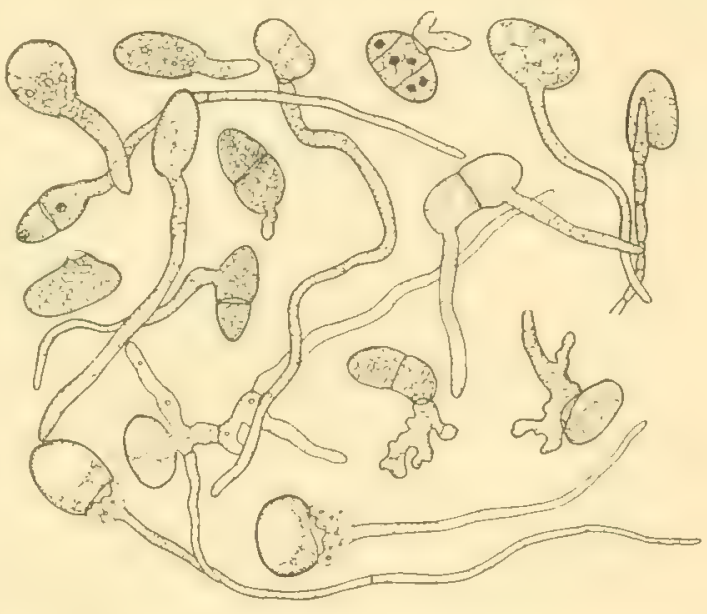

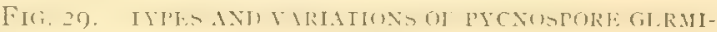
N.110N

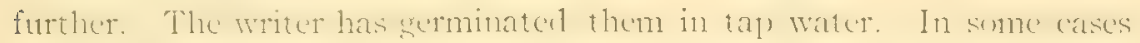

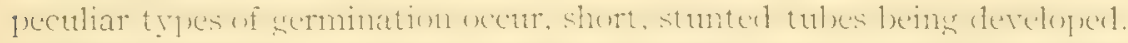
In other cases the proxess is entirely inhiluterl, and in certain of these cases the layine form of a crosimall talies place instead. In one ubservation notes were made as follows:

Spores one-celled when collected (May 13, 1913). Placed to germinate in tap water and after twenty-four hours the two-celled spores had not germinated; the one-celled spores had developed tubes about $3 \mathrm{C} \mu$ long: After forty-two hours some of the twocelled spores developed tubes ahout $175 \mu$ in length, whereas the germ tubes of the one-celled forms were about $500 \mu$ long.

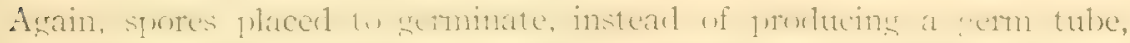

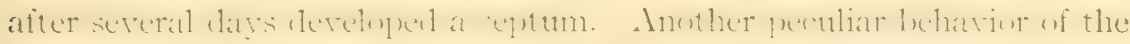

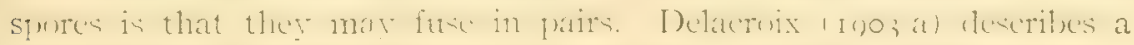

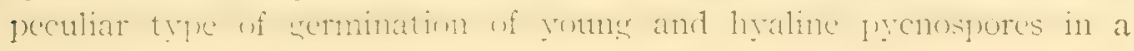


solution of 2.5 per cent of sluene and I per cent of peptinne. No crosswall was developed. After the third day the wall broke and the eontents emerged, formins a loud on the surface of the sione. This spllerule may attain a diameter of from $3.5 \mathrm{to} 40 \mu$; its further development was not followed hy Delacroix. The writer has observed similar bellatior of pyenospores, except that the swollen parts finally developed a sem tulxe. This took place in tap water. In some cascs older spores burst and fail to send out a germ tube.

The effect of low temperatures on pycnospore sermination was noticed in the syring of IOI.3 in eonnection with infection experiments. () M May 15, IOI2, spores in clops of tap water on a glass slide were placed in a petri dish, plenty of water was supplied to prevent dryins out, and the culture was placed out of loors, where the temperature ranged lectween so and $10^{\circ} \mathrm{C}$. A second calture was kept at room temperature $\left(2 \mathrm{I}^{\circ} \mathrm{C}\right.$.). No germinations necurred outside, hut the cultures kent in the lathrotory at

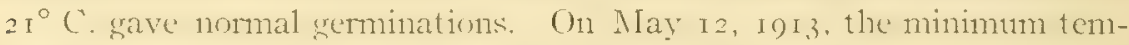
perature wats o ${ }^{\circ} \mathrm{C}$, the maximum $15.5^{\circ} \mathrm{C}$. All spores nut of doors failed to germinate at these temperatures, while those at $2 \mathrm{I}^{\circ} \mathrm{C}$. gave nommal germination. (Jn May I.3, I0, and 20, In I3, when the maximum temperature was $15.5^{\circ} \mathrm{C}$.. similar results were ohtained, exeept that in one culture

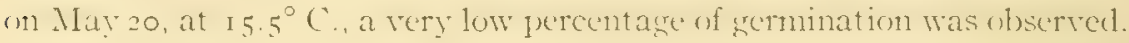

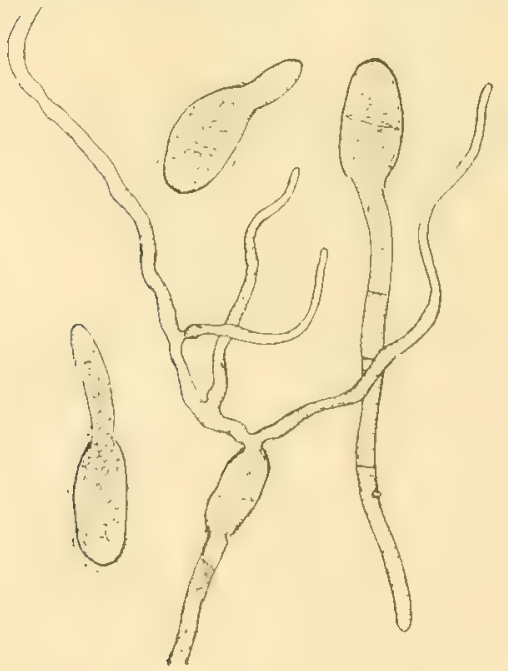

FIG. 30, STAGES IN THE GERMINATION OF ASCOSPORES

This indicates that in most cases a temperature of $15.5^{\circ} \mathrm{C}$. is unfavorable for germination, and that below that point germination fails. Delacroix ( I903 a: I39) states that mature spores germinate after forty-oight hours at a temperature of about $16^{\circ} \mathrm{C}$. $\left(60.8^{\circ} \mathrm{F}\right.$.).

ASCOSPORE GERMINATION (Fig. 30). The ascospores germinate readily in tap water and potato agar. The time required for the process is from six to twelve hours. In some cases a septum is developed in the ascospore during germination.

INCUBATION PERIOD. The period of incubation on apple bark, as stated by Potebnia (1907:16), is about four days. On foliage it is about five days, according to the olservations of Scott and Rorer ( I oos:50 5I). Incoulations made by the writer on bark show that the time betweren 
inoculation and the first sign of the diseatse is from two th serem delys, varying with the strans of the fungus used and the metemolegrical eom-

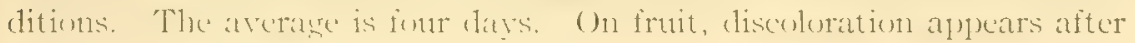
from twenty-four to forty-eight hours.

PATHOLOGICAL HISTOLOGY. Frmit.- If a section of an apple fruit is

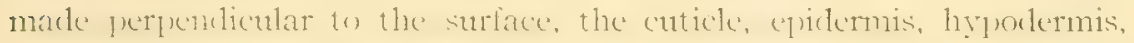

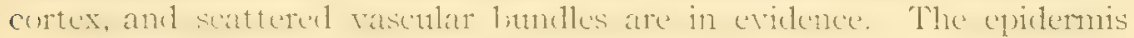
is compused of a single lager of revtangulat cells, the onter walls of which are stombly thelened by a waxy infiltration to form the cuticle

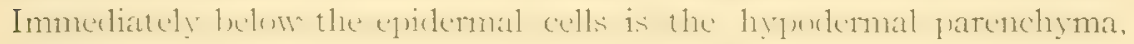
the cells of which are distinctly different from those more deeply

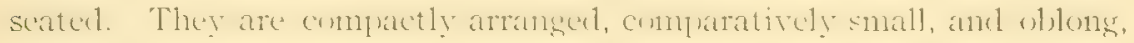
with the greater diameter parallel to the surface. They, contain the coloring matter of the fruit. There is a gradual transition from these colls to the latse isudiametric (colls that make up the masis of the apple tisste. The veinlets come from ten main veins and by continued branching the bundles become scattered, being finally lost in the cortex.

There is a sharp line of demareation lectreen the leathy and the

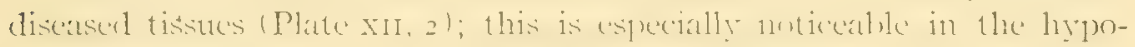
dermat parenchyma. The crilorins matter is atumbatht in the nomal cells of the hypulemis; at the junction of the 1 wo rewions the colnation is lost very abrupuly and the tisite is a distinet bromm. All the afiected regron is fromen and the discoloration in the cortex extends beymel that in the

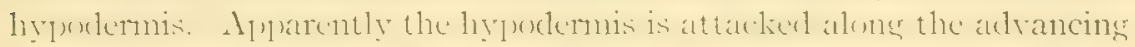
marrin of the levion from the cortex belon. The mycelium of the fungus

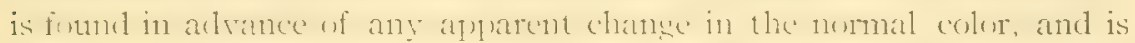
foutud in the cortex first, at a pritut screral cells in atrance of the affected hypulermal colls. The hypulermis appears to be undemninerl. The walls of the colls in this resion are sreatly thiclined; the process is apparent

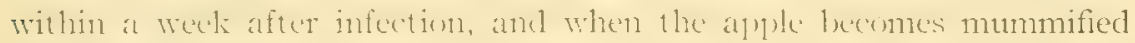
the lumen of the cell is nearly clesert. Dandeno (1000) states that there is a proluction of celluluse in the cell wall of the apple in the crourse of

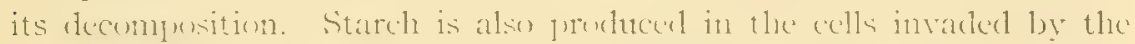
mycelium of the fungus, lnt with the thicliening the stareh srains disappear. The excessive thichening is resarded by I)andeno as resulting in the preservation of the mummy.

The mycolinum is usually, if not always, intercellular. In thick, freehand sections strateds may be foumd cressing the cell cavity, lut cell-wall penetration has not heen observerl. Firecpuetely small thearls appear to pass into the cell of the host from the parent loranch which is in the intercellular space, but no opening in the host-cell wall has been seen. 


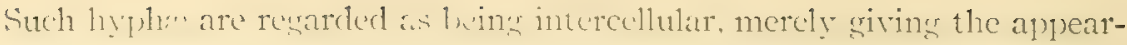
ance of an intrazellular habit because of the thickness of the section;

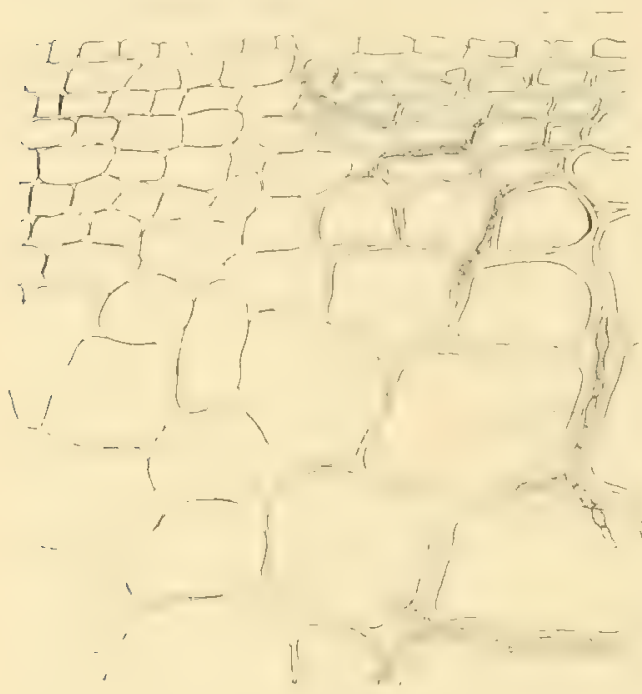

FIG. 3I. HISTOLOGICAL CHINGES IN THE FRUIT OF APPLE

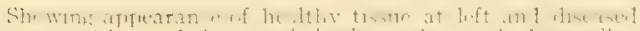

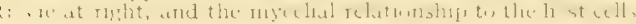
in thin, microtomed sections the threads are found between the cells. In ccrtain cases the hyphxe appear to le within the cells, but one may mistake a large intercellular space for a cell lumen. Dandeno (Ino6) states that the mycelium is intercellular, but that small threads enter the cells and even pass through them (Fig. 3I).

Leares.-The lesion produced on the leaf is largely necrotic. The cells are brown, collapsed, and obviously dead. The average thickness of the normal apple leaf is about I $42 \mu$, whereas that of the discases area is about 6r $\mu$ (Fig. 32).

The epidermal cells of the affecter tisstes are flattened and lear little

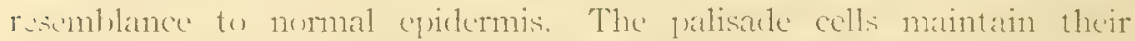

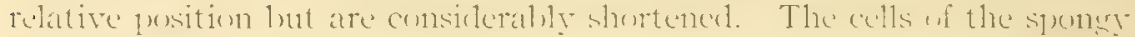
parenchyma are shriveled and irregular in form (Fig. 32).

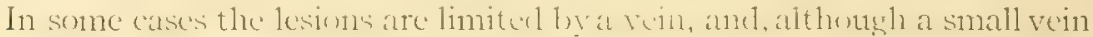
may mark the extent of the diseased area, the larger veins more frequently act in this capacity. In cases in which the edge of the spot does not fall at a vein, a plate of cells surrounds the lesion and limits, for a time at least, the extent of the fungus.

The structure of the leaf at the margin of a spot is rery different from either the

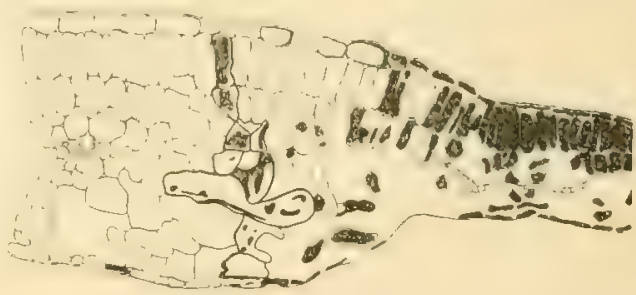

Fig. 32. IIISTOLOGical CHANGes IN Diseased LEAF TISSUE

Showing healthy and diseased tissue. The beginning of

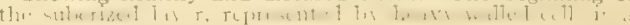
line from epidermis to epidermis, should be noted healliy or the deat parts. The process of differentiation apparently takes place in considerathe artvatnee of the fungus. In some stained sections 
a row of cells with dark-stained walls is seen in the leaf (Fig. 32). They are arranged in a direct line from the upper to the lower epidernis. This involves the palisade cells and the spongry parenchyma,

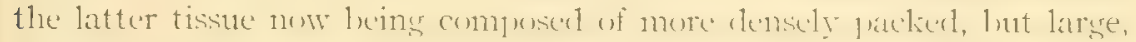
cells. With the alvance of the fungus this laycer increases in size and number of cells until the diameter is increased were that wit the nomal part. An arlditional layer of pratisarle cells may le develogerl in this region, hut in a late stage the entire mestiphyll becomes dentedy filled with large, irregularly shaper cells. The chongated palisade eells are completely changexl and beome isediancetric in fomm. The applatent stimulation results in hyperplasia and metaplasia of the palisade cells and in hyperplasia of the spongy tissue (Fig. 3.3).

The disensed cells give a test fir sulurin with chlor-indirte of zinc and with cyanine-glycerin. Certain stages in the develogment of the leaf spot show discoloration of the epidermal cells up to the suberized layer only. Later, however, the epidermal cells are affected beyond this region, as evidenced by their loss of normal size and color. It appears that penetration of the temporary layer is accomplished hy the fungus invaring the epidermal cells and thence advancing into the healthy tissue. At any rate the my-

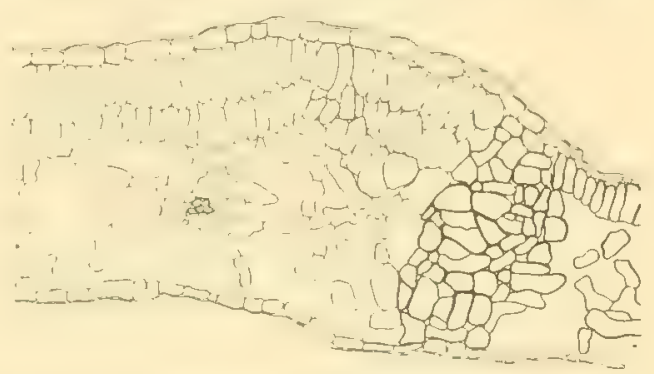

FHa. 3.3. HISTULGgICAL CHANGiS IN DISEASI D LEAF TISSUE

Shuming the rear tima, if the het al ing the matrin of

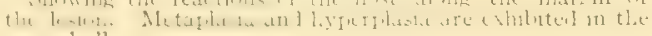
mesophyll

celium is found in the epritermal cells in this region. The alternate processes of the formation of this layer of tisitle, and the suldserguent invasion of the tissue feromel the suluerized layer by the parasite, give rise to the concentric rings previously described.

Burk. - The tissues of the momal apple stem represemt the condition found in a typical dicotyledmons pliant. In the center is the gith, radiating from which region are alternate medullary rays and fitnorasenlar bundles. Ontside these is a cylinder of secondary cortex, which is in turn surrounded by a cylinder of thicli-walled cortex (pmoldally primary in nature) and (me of corte or periflerm. In older stems the cpidemis is not present. The secondary cortex is compued of sereral layers of phloem, in turn made up, of hard, or listified, sclerenchyma fihers, sieve tulus, companion cells, and phloxm parmeylma. In at lometurlinal section the nnelullary rays are prominent and are perpendicular to the periderm. In the secondary cortex the se retys are connected ley rows of 
phloem parenchyma which are oriented at right angles to the direction of the meaullary rays. These phloem parenchyma cells are rectangular and similar to the medullary ray cells: the arrangement of the former results in the noticeable stratification of the secondary cortex.

The material for comparative study of healthy and diseased tisstes was usually taken so that both areas would appear in the same section. Cankers from natural and artificial infection were fixed in Gilson's fixer

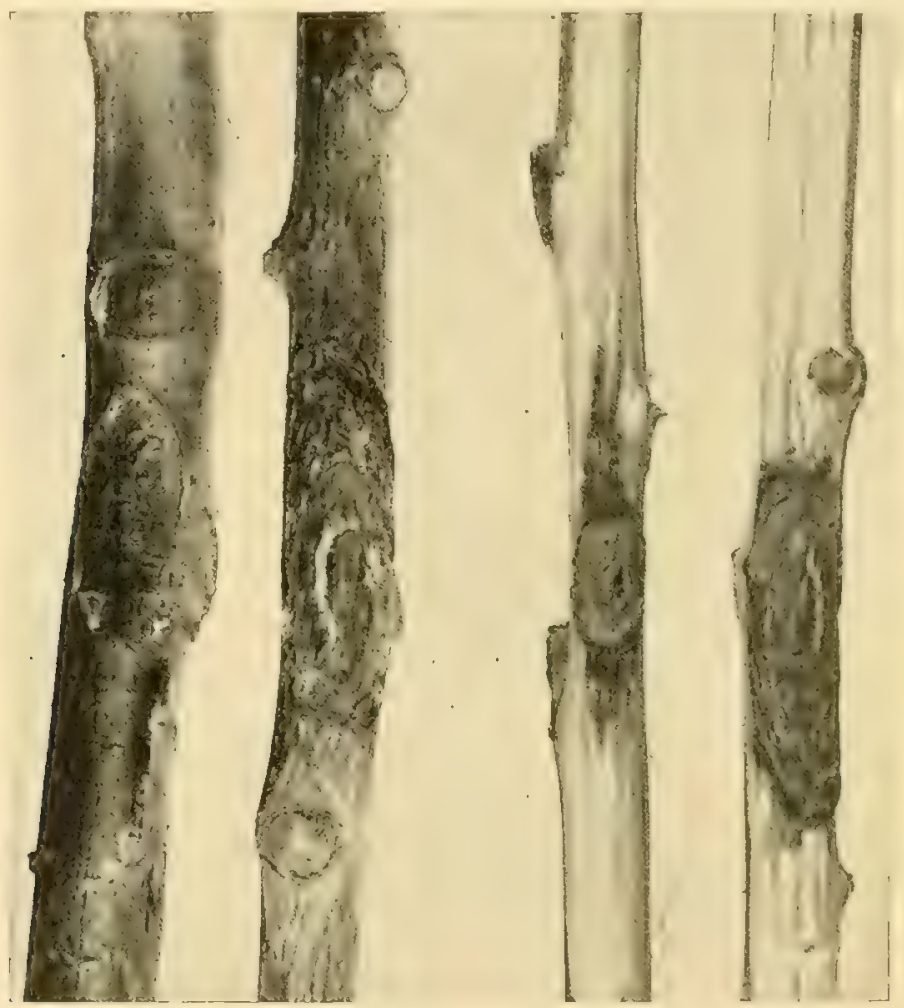

FIG. 34 . HISTOLOGICAL CHANGES IN DISEASED WOOD

Two apple twigs, showing cankers as they appear on surface. The specimens on the right are the same twigs, with bark removed to show the streak

or in chrom-acetic acid, hardened in the usual manner, and finally imbedded in either celloidin or collodion. Sections made from such material, as well as from fresh tissue, were cut with a desk microtome and stained with the following stains: safranine and nuethyl hlue; safranine and methyl green; phloroglucin; and a chlorophyll solution.

In the normal tissues the lignified and stberized tissues - that is, cork and hard sclerenchyma fibers - are stained red with safranin, whereas 
the cellulose tissues, cortical and methllary, are celoted hlue with methyl-

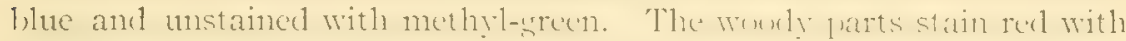
phloroglucin. In the discasert part there is a vety prominent general

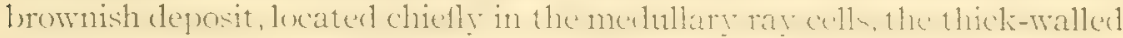

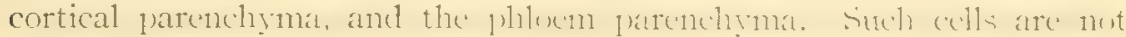
stained by any of the stains wist. The selerenchyma filxes and the corts are colored red by safranine, whereas suberized cork cells are made green with a chlorophyll solution. Diseased wood shows a test for lignin phloroglucin.

The more striking external symptoms of the canker noted are the discoloration of the bark, a crevice at the margin of the lesion, and a sinking of the tissues. It has been noted elsewhere that the organism penetrates the wood to a limited extent only, so that the more notable changes occur in the bark. The canler is sometimes superficial, the attacks of the organism being confined to the cortical tissues. Attacks on the wood of old limbs are not frequent, luat on twigs the wool is subject to common invasion by the parasite. In cross and lon-

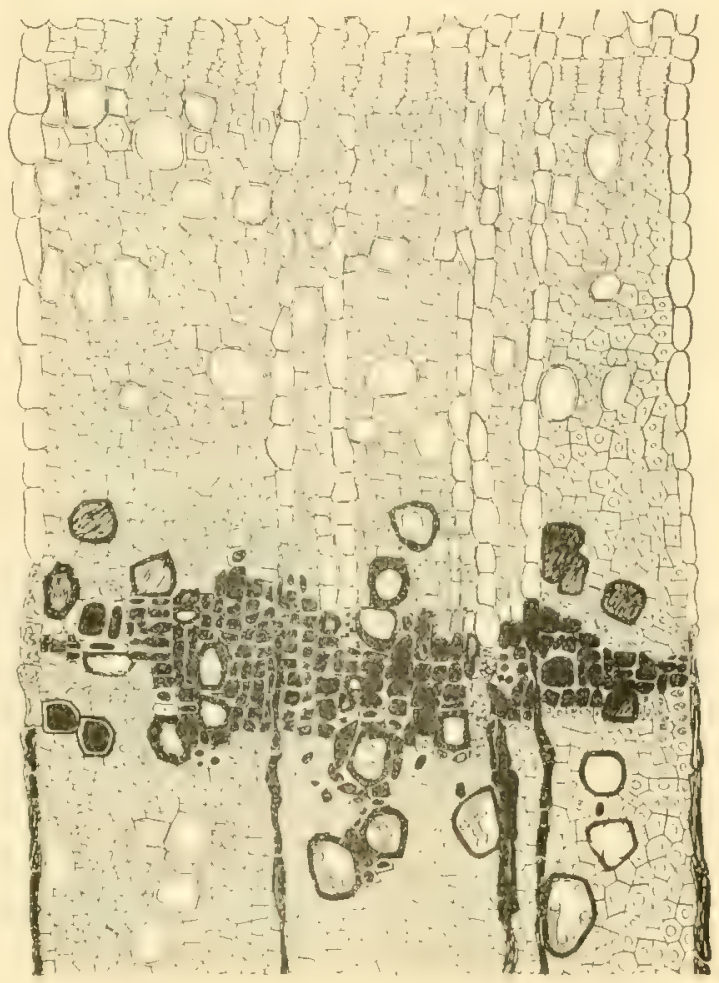

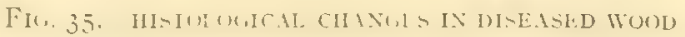
Cross section of part of apple twig, showing brown deposit in

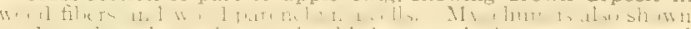

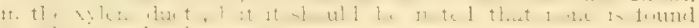

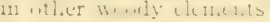

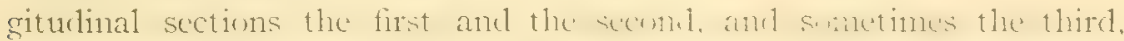

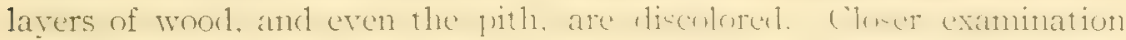

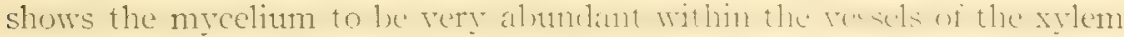
and in the wondy parenchyma. In thi resinn the chameteristic lorom deposit is found, lout is located chictly in the edly of the medullary rays and the woud parenchynat. Inwoulations on young apple trees in the greenhouse with the ascospore strain (no. 82, from apple) show that 
there is a streak developed in the outer layers of wood (Fig. 34), just as in the twig blight on chestnut oak. ()ucrcus primus, as reported by Ingram (1912) and noted subserpently by Rankin (I9It). The streak is due to the discoloration of the colls, not to the presence of the mycelium (Figs. 35 and 36). Onc las only to examine longisections through the streak to be convined that the hyphal threads do not grow in strands and are not otherwise arranged so as to give such an appearance to the tissue.

In the case of the more superficial cankers the ingress of the fungus is cut off from the healthy tissuc by the development of a cork layer (Fig. 37). Such lesions reveal in section the presence of a layer approximating the normal periderm, with which it is continuous and which reacts the same

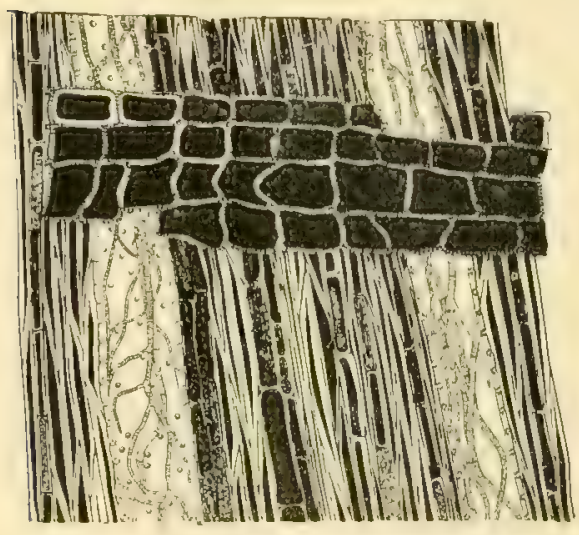

Fig. 36. Histolocical CHANGes IN DISEASED WOON

Longsection of a part of apple twix, shoring hirnwn deprisit in winly rlements. Myceliunis is again to be seen in the xylem ducts with safranine and with a chlorophyll solution. These cells in their final state are suberized.

The layer originates by the division of cells of the cortical parenchyma. The sclerenchyma fibers are not changed. If the layer comes in contact with a group of sclerenchyma fibers it is inter rupted. The more recently affecte. cells - that is, those nearest the margin of the lesion - show a reddish tinge with safranine, ind1cating slight suberization throughout the region. Later, evidence of the cork layer is found just beyond the infected zone. Walls are laid down to form rectangular cells characteristic of the final cork layer and of the nomal periderm. At this time they do not take the safranine, indicating that suberization has not begun. Such sections stained with chloroplyyll solution also show no suberin reaction.

A later examination of the marginal layer between healthy and diseased tissue stained with safranine will reveal three distinct and characteristic zones, as follows (enumerating entad): a red layer of three or four suberized cork cells; a colorless layer of about two non-suberized cells, rectangular; and a third layer of about two smaller cells of the same shape bearing a brownish deposit, making a distinct brown line. Many slides show the reverse relation with respect to the suberized and cellulose layers; the colorless layer, composed of colls with cellulose walls, may lic next to the diseased tissue, and the cells with stherized walls next to the brown line. 


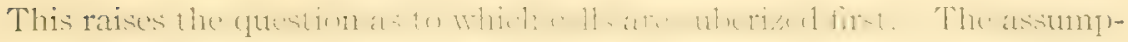

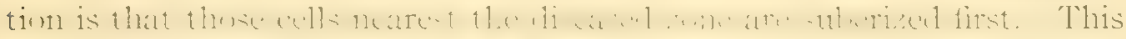

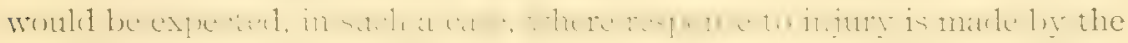
host. But this scarcely explains the cases in which the colorless layer borders the affected tissue. In these cases, however, the brown line

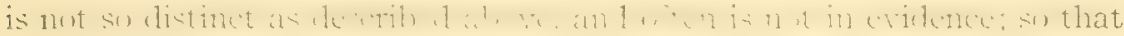
this may stand as a younger stage in the formation of the cork layer. The cells of the suberized layers do not react alike when stained with safranine. A row of cells in the center is the darkest, the color shading off on both sides, perhaps indicating the amount of suberization.

The majority of the cells of the layer are densely granular, are thin-walled at first, and possess large nuclei. These have the characteristics of rapidly dividing cells.

A section through a canker having a crevice at its margin shows that the break follows the brown line. The dead tissues on the one hand shrink, while the living; normal part increases in diameter by growth, exerting tension on all tissues of the bark, and the break results. It aplears that the (wlli milin. up the brown line are the

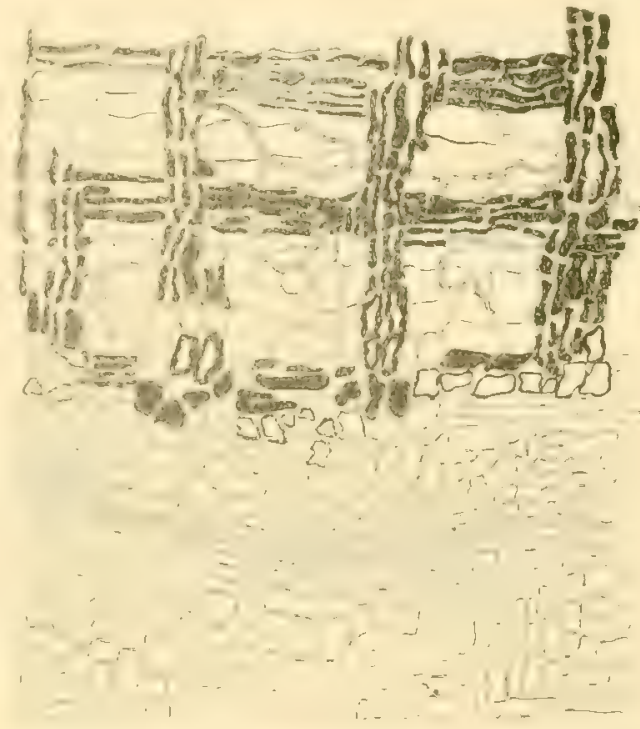

Figi, 37 . mistological changes in diseased BARK

Showing brown deposit in the medullary ray cells and phluem parenchyma, which cross at right angles resulting in

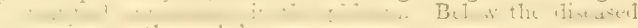
regron is seen the corta layer

weakest, and thus they mark the line of separation of the diseased from the healthy tissue.

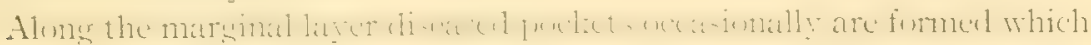

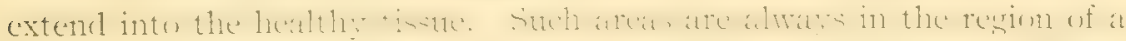

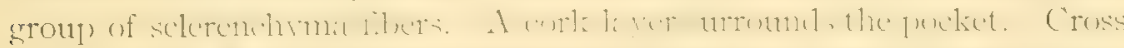

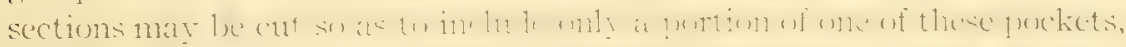

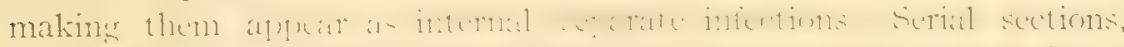

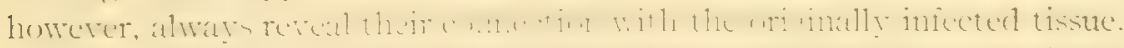

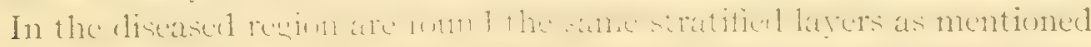

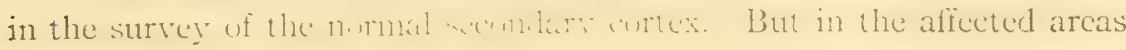


both the cells of the medullary rays and the phloem parenchyma stand out very prominently, being filled with the frownish depesit. The remainder of the old phloen chements, the sieve tulues, crompanion cells, and sclerenchyma fibers, are not discolored at all. (Fig. 37.)

The brown mycelium of the fungus is found very abundantly throughout the diseased area. It is intercellular, except when it cncounters the xylem and the hard sclerenchyma filers; it is not easy to say just what the relationship is with respect to hard sclerenchyma filers. It is noted disewhere that the hyphe are found within the tracheal tules. The threads for the most part pass up and down the stem. This is in accordance with the external symptoms of a lesion. It has been stated previously that where the cork layer encounters a group of sclerenchyma fibers it is interrupted, and the fungus breaks through the barricr as laid down by its host. There is no evidence that the suberized cells are ever penetrated. Mycelium is found advancing through the layer at points where the sclerenchyma fibers cross it, a discoloration precedes the hypher, and almost before the threads gret into the healthy tissuc the latter is changed in its normal color. Very soon after is found evidence of a secondary cork layer, which usually branches from the primary lifyer at sume puint beneath the point of secondary penetration. This cxtends around the newly affected region, finally passing above to the nomal periderm. Repetition of this process, accompanied by the formation of crevices at each successive cork layer, results in the concentric lines or cracks so characteristic, externally, of the lesion. The drying ont and death of the cells results in their collapse, and the affected part shrinlis.

\section{CONTROL}

\section{EXCLUSION BY LEGISLATION}

BLACK ROT

As previously noted (Evans, igro), the British Covernment at Cape Colony has legislated against black rot. Impurters are warned that, under a government notice of i gos, all comsignments of pomaceous fruits found infected with this organism to the extent of one fer cent and upward will be destroyed on arrival at the Colony or returiecl to the consigrnor. SPRAYING

It was suggested by Sturgis ( $\mathrm{I}_{0}, 3$ h) that spraving in August and September would prevent llack rot of quince. The following year the same author (1804) found that a $0.0 .3-1$ (recent solution of (oppler sulfate is fatal to the fungus. More recently. Waite (In)o6: In) recommends the same treatment as for aprle scab. Wolf (1nt3) concludes from experiments conducted in Alabama that bordeatx $4^{-4-50}$, applied as follows, will be effective: the first spraying, about July 15 , when the disease is just 
appearing: the second, two weks later. This schedule gave satisfactory control, the sprayed fruts showing less than nne per cent diseased on certain varicties. (ontrol was less emplete on Black Ben Davis, which exhibited from ten to fifteren per cent of black rot. Lime-sulfur was found to be wholly ineffective under southern conditions in I9r2.

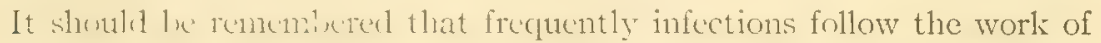

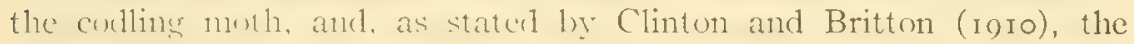
control of this inseret lessens the amount of rot starting at such centers. The work heretolore describud indicates that certain insects carry the spores; it is thereine importint to consider the control of these pests. HANDLING OF FRUITS

It is aprarent from the life history studies that spores of the black rot organism are puesent in the oncharel at picling time and are carried into storage. It has also been learned that the fungus effects penetration only throteh injured tissue. (insectuently one factor in olstaining apples of gond lieepring cunality is the climination of medhanical and other injuries to the fruit; the cecurrence of hlack on in strage is undoubtedly connected with the handling methods in use in the orchard.

STORAGE

It has been found hy Lamson ( $1902: 81$ ), and subsequently by Eustace (1908), that the temperature of the sturage room should be about $3 \mathrm{I}^{\circ}$ to $34^{\circ}$ F. $\left(-c .5^{\circ}\right.$ (n) $1,1^{\circ}\left(c^{\circ}\right)$. Higher temperatures allow growth of the funsus. It is important to note that when apples are stored in barrels, alout one reck is reculired for the temperature of the center of the receptacle to become equal to that of the storage room.

\section{SPRAYING}

LEAF SPOT

It secms that $A$ lwood ( 1 S.92) was the first to advocate the use of sprays for leaf sinut. He recomnuches two aprolications, as follows: the first, just as the petals lowe fallen from the apple, using bordeaux mixture 4-5 50; the second, alyut twenty to twenty-five days later. The recommendations of later writers differ in number of applications and in type of funcicicle. It is rery apparent that the number of sprayings in a given year will depend on the character of the season. Ordinarily two or three applications are neecssary, ateording to Brools (Igog, and 19r2, a and b) and others. In certain seisons of considerable rainfall additional sprayings may be necessary.

As previously mud, in some districts at least the leaves are infected shertlyafter the und hi fom the but, and infections may continue through-

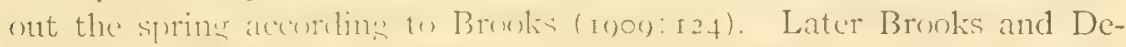

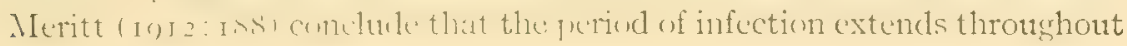


the middle of the summer. The number of applications then to be made will depend on the charatur of the :astisn and the alundance of spores present.

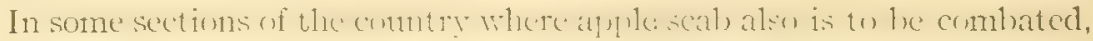

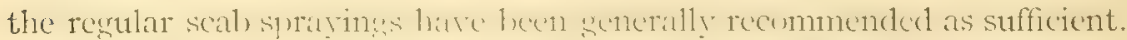

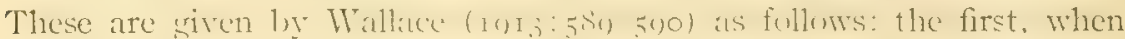
the hlossoms show pinl:; the sceond, alter the lilosems fall; the third, two or three weels liter. If liter suah sprarines are necessary, the leaf spot will te controllerl. Sout (reot:3,3) states that the disease may be controlled in connertion with the tratment for bitter rot; for the latter disease he recommend: from fonr to six applicatirne of bordeaux mixture, made at intervalis of two weeks beimning abnut six weeks after the trees blossom.

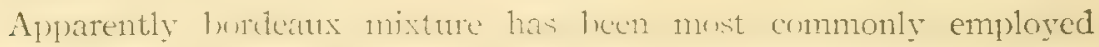

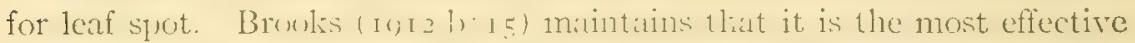
fungicide for apple discascu, lnt prints out that an objection to its use lies in the fact that spottine of the bulias and russeting of the fruit are likely to occur if showers follow its applicition. The sponts produced on the leares resemble throse catused by the fumbus. For leaf spot alone, Broolis (page \& of same reference) find that self-lociled lime-sulfur best holds the disease in check.

Lime-sulfur is rewarded hy Bronles (I0) 2 h) as a sativfactory substitute

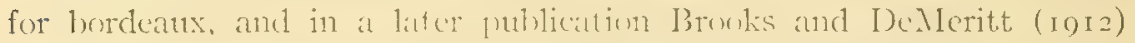
show that connercial linne-sulfur at a strensthe of one wallen to twenty-five sallons of water reduced the infection from athent 051 ex (ent to 26 per cent. When used at at strength of one gallone to fifty gallons of water, the lime-

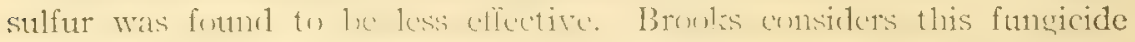

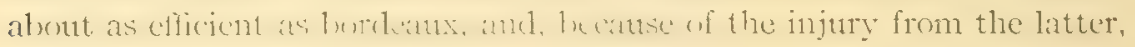
lime-sulfur would appear the more desirable.

\section{CULTIVATION}

Brooks and I) Meritt (1012) have observed marlied contrast between the amount of infertion in sul and in cultivated orchards. They record

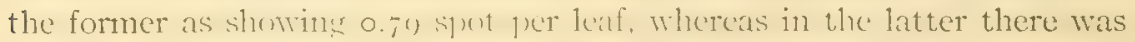
only 0.47 spot per leaf. They say (page 189 of reference cited):

The trees had been treated alike in every other respect and were of equal vigor when

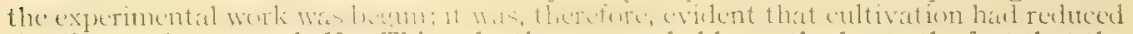
the disease almost one-half. "This reduction was probably partly due to the fact that the leaves were plowed under on the cultivated plots, but the lack of general vigor in the trees on the sod plots was apparently partly responsible for the difference.

\section{HISTORICAL AND INTRODUCTORI}

The control of canliers hat l xert a matler of ensideration for some time. Nearly three centuries aten l'arkinsinn (1020):550) recommended surgical 
methods together with a wound dressinger of vincurat. Similat advice is

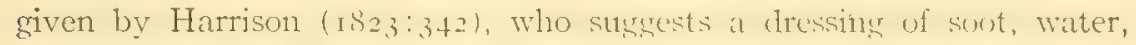
and trait oil. He recommends drainage of the soil in serere cases.

In more recent times, begiming with the apluearames of the work of Paddock (ISog b), the recommendations are all csscutially of the same nature. The employment of the common methods of orchard manasement - cultivation, fertilization, prunins, and sprayines - is recommended, in order to promeste seneral vieror. Feemine the trees in grood growing condition is claimed to be essential (Wamen and MICCome, I005). Spraying to protect the bark is frecpuently recommended (13ethune, in on: 30 , and others), while scrapiner the hark and applying a wash is strecerested by Paddock (rsoglo: roo) and others. Pruning of discased limbs and the growing of a new top is being practiced by some growers.

The control measures more commonly employed ly the stowers of New York State are pruniner and spraying: other meatsures, as determined by circular letters and personal observation, are suruers, cultivation, fertilization, and mulching. The sucess of these methods raries and seems to depend on the vigilane with which the srower pursues the disease.

\section{SURGICAL METHODS}

PRUNING. In pruning for the control of canker, two methods may be employed: the limb may he cut from the trec entirely, or the cankered bark may be removed. In either case a wound will result and the application of a dressing becomes essential.

Remoral of limls.- The question frequently arises, when shall only the canlier be cut out, and when is it necessary to remove the limb? No general mule can be laid down, but each ease must he examined carefully and procedure talien accordingly. If the limb is larse and productive, its removal should the postponed. This is commonly the practice. But to wait until the limb is not producing satistactorily usually means that the canker will aid in brinsing the branch to destruction. In such cases it is advisable to prevent the loss by eradicatines the cankered sisot by surgery.

If the limb is not producing, whether large or small, its removal for the purpose of eliminating the fungus is the alternative. The cut should be made so that another limb, or water sprunt, may ixe allowed to grow in the approximate space left by the part removed. This method of treating the New York apple tree canlier is employed in certain orchards along the Lahe Ontario belt in this Sitate. One cromer is very successful in this measure of control. This, with joutection from nem infections by careful spraying of the entire tree - trunk and limbs - renders even the highly susceptible Twenty Ounce variety Inactically free from cantier 
Graftines of stubs icft by the pruning of the affected parts of limbs is occasionally pricticed. This may be justified in certain cases, although as a rule it should te supplemented in the main by the method just described.

Remoral of disrased hark. - The cutting out of cankers is a method to be employed when the urower is satisficd that the value of the limb warrants it. An ittempt to remove all kinds and sizes of cankers from an infested orchard withont resard to such a consideration is likely to result in the discourafment of the orchardist with the whole undertaking. The equipment necessary for use in the removal of cankered bark consists of a drawshave and a farrier's knife. The limits of the diseased area are ordinarily deternined by making an external examination of the canlier. Where this method is not relialile. small bits of the outer hark may be removed, following the line of the discoloration until the limits are determined. Similarly the depth of the canker is defined.

The shape of the eut will vary somewhat with that of the canker to be removed. So far as possille, the wound when finally finished should be lenticular in form. This will facilitate callus formation. If the wound is rectangular the upper and lomer edges heal more slowly. The edge of the wrund should be perpendicular to the long axis of the limb), for cuts made at a slant will result in a certain anount of dead cortex, which is undesiralle from the standpuint of new infections. A possible exception to this method of trimming the margin is to be found at the lower end of the wound. Ifere the edge should he slanting enough to permit drainage of moisture.

WOXND TREATMENT. It is frequently advised that the wound should be disinfected and protected. The latter is certainly commendable practice. lut whether the former is necessary will depend on the nature of the wound dressing.

Iround disinfotion.-If the dresing itself is a disinfectant, a special disinfectant will not be necessary. In case one is needed, mercuric chloride at the ustual strength ( I rooo), or copper sulfate (I ounce to I gallon of water), is most commonly used.

Wound protition.- - The necessity of a protective covering for wounds is twofold: whe dis the weat hering of the wound, and to prevent the growth of bacteria and fungi. It follows, then, that the fundamental requirement of a round dressing is that it should be a preservative and a preventive. Briefly, then, the dressing should have antiseptic qualities, and should be fluid, reasmably inexpensise, and easily prepared and applied; it is essential that it should wive complete covering; it must be impervious to air and water, must le durahle, and must not injure nor kill the tissues nor interfere with the healing process. 
The preparations now most commonly used are paint, tars, and asphaltum. In some cases commercial tree paints are muployed. It is generally agreed that paints are an incficient oxering. whereas asphaltum once applied grives the desired protection. Asphaltum, hurverer, is more difficult to apply. This is particularly true if the aspholtum used is rendered liquid by heat; if it is dissolved in satsoline it is morc (asily prepared and hence more availatile. 'The combination of asphaltum and gasoline has been applied rather extensively in the erehorel of Fred Hazleton, at Leroy, New York, and from all alpuatrances is commendithe.

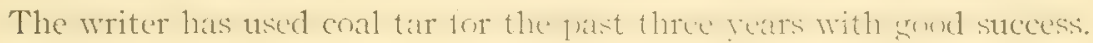
This is a residual tar derivel in the manufactume of artificiai gas from coal. According to Lonnge (r oon), tars may vary exen from the same materials, depending on the temperature used in the distillation, the shate of the retort, and other factors. The use of coul tat ats a wruml dressing has been reconmended to growers of the State, and some hare complatined of injury to the healthy tissue from its use while whers repert it ats an apprepriate material. Many cases of injury have bect found we hase resulted from the nse of creosute, lut not from coral tar. The pruncer must distinguish between the two materials. The writer has neren sectn any cases of injury from coal tar on apple trecs, and it has heche used sucecessfully

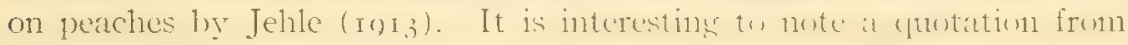
Des Cars as given by Bailey (Igo7: III-II3):

The application of coal tar should not be made except with considerable caution in the treatment of wounds on drupaceous fruits (cherries, peaches, plums, etc.), and especially on the plum tree. It has often been observed that the bark of fruit trees

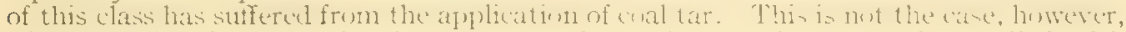
with pome-bearing trees (apples, pears, etc.); to these coal tar may be applied with perfect, safety.

Card (Isoz:0) reports experinents in pruning in which he tested varions

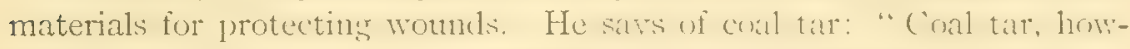
ever, scems to have leen a positive hindrance to the healing process, not one wound having been reported as healing extrencly well. while the majority are reported as healing only fairly well." As it comment on this remark, Bailey ( I $) 07$ : I I, 3) ays: "It is nut saicl, horrerer, whether the tar injured the tissues, or whether the apparent results may non have lexen due to the position and character of the wonnel (puite as muth ats to the dressing. In my own experiments . . . . tar did no damage."

In view of the complaints made of injury from the the of cual tar, it occurred to the writer that this sulsstance varied sufficiontly in different parts of the State to accunnt for the injury, if any exer cecurrel. Samples were obtitined from the ras plants in the following citics in Now York:

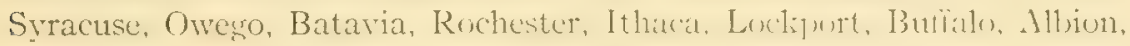
and Geneva. These samples were applied to wounds of mature apple 
trees on the farm of Dr. Johnson, at Leroy, New York, in August, i 912. Examination at intervals during the growing seasons of $19 \mathrm{I} 2$ and $19 \mathrm{I} 3$ showed equally good healing and no injury. Another orchard, near Batavia, New Tork, owned by Chapin \& Son, has been extensively treated with coal tar, with results similar to those just described. The writer has applied coal tar to Northern Spy, Baldwin, and Hubloardston apples in an orchard at Byron. New lork, and no detrimental effects have been observed. In some cases the wound has been disinfected by the use of mercuric chloride ( $\mathrm{I}-\mathrm{I} 000$ ), but no difference in the efficiency of protection was observed between wounds so treated and those not disinfected. The writer feels safe in recommending the use of coal tar without previously disinfecting the wounded surface.

The cost of canker treatment - that is, the removal of discased bark and the application of a dressing - is not an easy matter to determine. Where it is done extcnsively the grower usually does the work along with the regular pruninis, so that the cost of canker treatment alone can hardly be separated from that of the whole operation. In an apple orchard at Leroy, New Yorli, careful work was done in in a by A. S. Davis. The orchard contained 050 furty-years-old trees. The orchard had been neglected for several years, and dead limbs, cankers, collar rot, and heart rot were abundant. Mr. Davis furnishes the follorving figures:

Cost of trimming.

Coal tar, to gallons, at 20 cents a gallon.

8.00

Corrosive sublimate

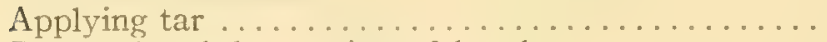

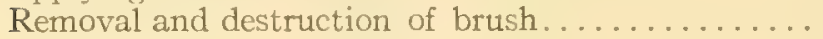

Total

The following data are taken from a similar orchard at Batavia, New York:

Miscellaneous data

Number of trees.................. 360

Age of trees.................... 30 years

Cost

Labor, 348 hours, at 25 cents an hour........

Coal tar, Io gallons, at 15 cents a gallon......

Corrosive sublimate.................

Total

$\$ 87.00$

I. 50

.50

$\$ 89.00$

It is seen that the arerage cost of the work in the Leroy orchard is about fifty-two cents a tree. It must be borne in mind that the orchard 
had not been pruned in several years, which accounts in part for the

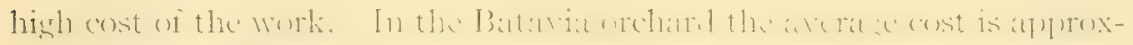

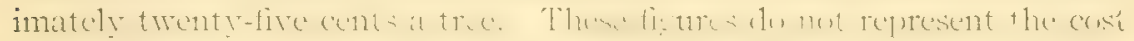

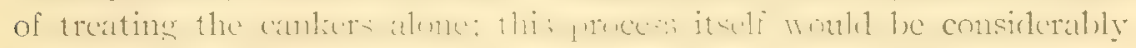
less than either of the above figures.

WOUND HEALING. Wround cork.-According to Hartig (rS94:225), whenever the living phellogen is injured a new zone of phellogen, or

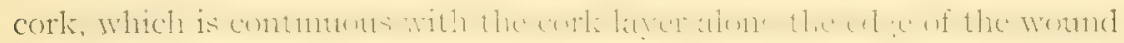

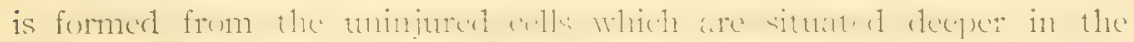
cortex. The cortical parenchyma, which lies beneath the periderm,

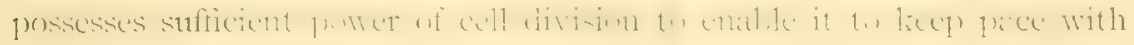
the increasing thickness of the stem. But in the case of the wound its

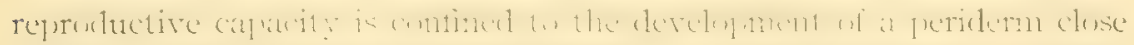

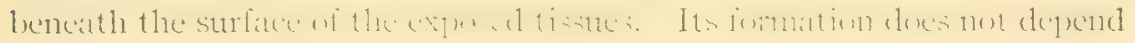
on the season of the year, but it may be formed even in winter.

Wround wood.- Hartig (IS94:228) states that wood exposed by a

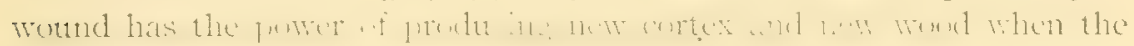
cambium is active and when the cambium layer and young wood are protected from drought. In such a case, regeneration of the corering

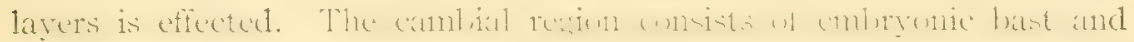

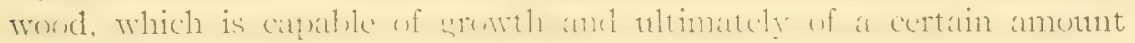
of differentiation. The wood thus formed is termed wound wood.

Callus. - Callus may be developed when the cambium has dried up

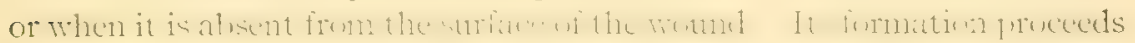

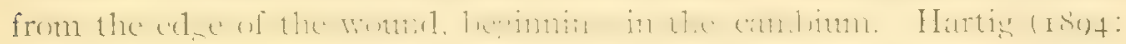
23 I) states that it is a purely mechanical process and results from the

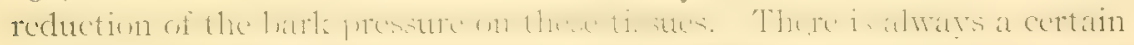

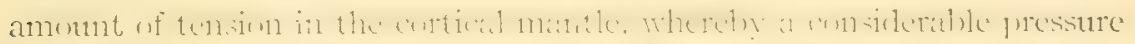

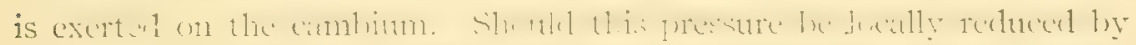

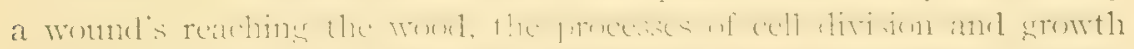

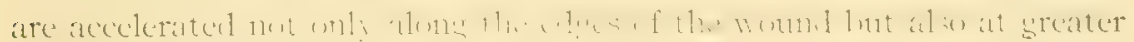

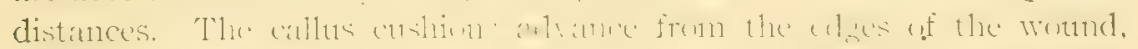

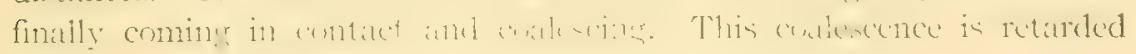
if the callus is clothed at an early stage with dead bark.

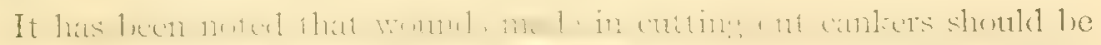

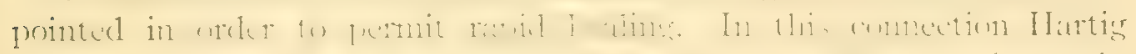

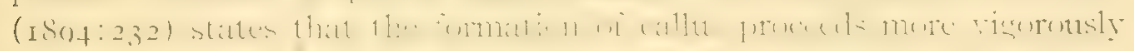

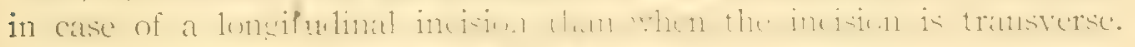

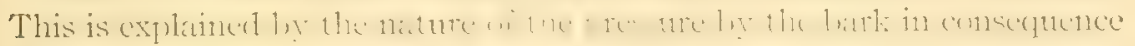

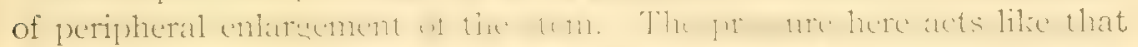

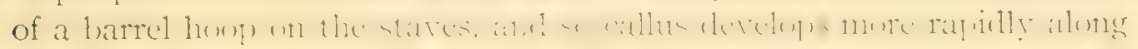
the lateral margins of the woml. In this connection the glustion of 
slitting the lower edge of the callus arises. Reasoning from the data regarding the development of the callus, it secms advisable to practice this operation each year; this prevents the callus from bunching, and stimulates it to more ready occlusion of the wound.

\section{SPRAYING}

The effectiveness of spraying for canker is a question frequently raised. It is the belief of the writer that spraying as a prerentive, but not as a cure, is worthy of attention. It is true, hoverer, that srowers report cases of curing canker by spraying. The fungus nuycelium is protected by the bark; hence sprays will not reach it, and eradication of the fungus from a given lesion by spraying seems highly impussible. Sivraying to protect healthy bark from infections would certainly appear adrisable, but the data at hand are somewhat conflicting. The writer recalls an orchard in which canker does not occur. The trees are sprayed carefully each year, according to general recommendations for ajples. Some of the trees are Twenty Ounce, lut they are free from the discase. The limbs are kept coated with spray throughont the summer, and as late as the middle of August these trees are still covered. In contrast to this orchard, another is recalled which is severcly affected with canker, ret the trees are given the regular sprayings. The difference in these cases may be accounted for by the lack of thoroughness of the spraying in the second orchard. Since protection is the principle involved in this method of control of canker, the success of any attempts in this direction is determined by the completeness of the covering.

\section{GENERAL CONSIDERATIONS}

The destruction of rubbish alout the orchard is no new suggestion. Peck ( $879: 21$ ) recommends that alfected fruit should be removed from the orchard and destroyed. The destruction of fallen leaves is recommended by Alwood (1892). Sheldon (1905) and others sugerest picking rotted fruit before the fungus spores mature in the case of quince black rot: Sheldon adds that this might not be possible with applles because of the size of the trees. In Alabama, howerer, Wolf ( I o I 3 ), ats has been previonsly noted, controlled the discase by spraying. The opinion is held by Brooks and DeMeritt (1912: ISo) that affecter leaves should lo plowed under. while clean cultivation is the recommendation of Reed. Cooley, and Rogers (1912:5). The remoral and burning of affected liml ss is adrocated by Bethune ( $1909: 30$ ) and others.

The ability of the fungus to pass from one part of the apple tree to another only adds to the sources of inoculum, so that sanitary measures become of special importance. 


\section{ORCHARD MANAGEMENT}

The value of carciul landling of fruit to prevent injury has been cmplasizent. 'This is hasul an the principle that the causal or anasm is a woumel fallatite. The sime care shonld be exercised with reference to the hatre of the tree; injury should be avolded whenever possible. Iniuries to barli are likely to result from cultivating implements and

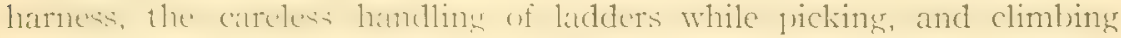

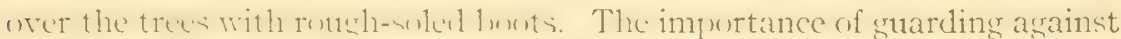
such orchard practice lies in the fact that cantiors begrin in just this sort of place.

It has been mentioned that the fungus follows winter injury. As a protectim against winter injury. Rentick (1012.37) advecates carly fllowing in the sming and cultivation to sive the trees the advantage of conservert monsture; he romminemels that cultivation should cease not later than dustest $x$, in wrike 10 start the trees into maturation. Corer crops, w talie up eseres misture in the autumn, should be sown. Soil drainute in low armund, and a wruxi circulation of air, are important considerations.

When it is llsired to arm: rarieties that ate susceptible, the canker

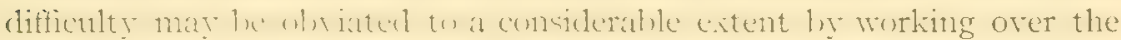

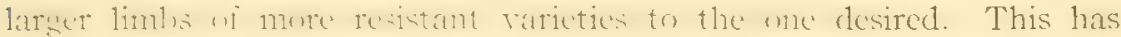
heen done with alplatent sucess in a few instances. The difficulties

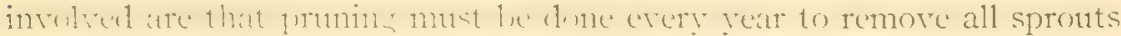

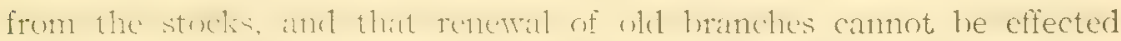

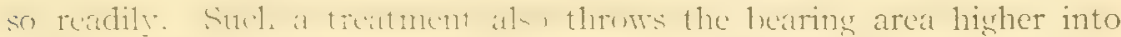

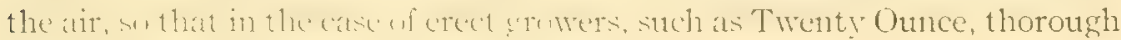
orchard operations are made more difficult.

\section{RESISTANT VARIETIES}

Since curtain rarieticin the apple - for example, Esopus and Twenty

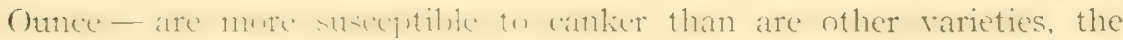

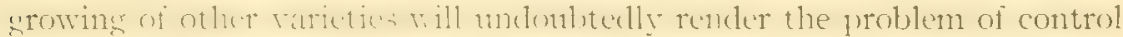
less diffictult. Twenty (unue, huwerer. is one of the most satisfactory fall varieties fir commercial planting in New Jork State. The question therefure arises, whe ther the medardist should sacrifice the growing of this variety in the hope of escaping the problem of canker control. The ericlence at hand indicates that it at wower wishes to raise Trenty Ounce. his success in lieepring the trees free from comlier will depend on his efforts. Observatime warment this epinum. It is true that, as stated by Warren

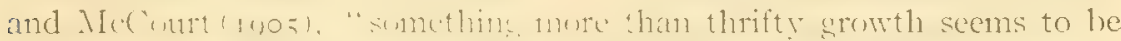

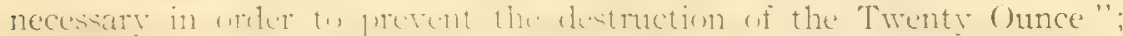

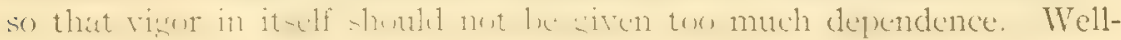


cared-for trees of this variuty are wfun severely cankered. It is assumed that the trees nutus $1 x$ in a thrifty condition in order to give the best results, but the control problun rous nut end here, for vigor does not establish nor maintain resistance.

\section{AN ENEMY OF THE PATHOGENE}

Potebnia (ior2) ne rentes an interesting case of a fungus, Helicomoces Sphacropsidis Potelmia, living as a parasite within the conidia of Sphacropsis psculodiplodir [ Phyalospora C'ydomiac]. Infection takes

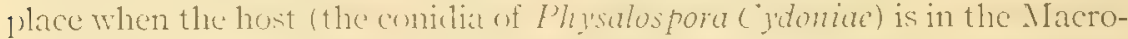

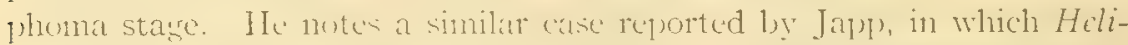

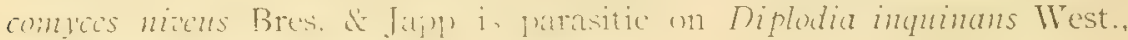
and states that in Japlis herlutrime specimen all pycnospores in the infected pycnidia were killed by this parasite.

\section{BIBLIOGRAPHY}

\section{(Anonymous)}

I899 a The app e canker. Country gent. 64:88.

Briefly summarizes the works of Waite and Paddock.

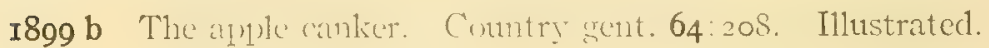

The illustration is a text figure, and the author contends that it is the first figure of the disease published.

I899 c Perhaps apple canker. Country gent. 64:248.

A reply to an inquiry concerning the apple injury which is regarded as caused by Sphaeropsis Malorum. Remedy suggested.

\section{Alderman, W. H., Gjddings, N. J., and Rumsey, W. E.}

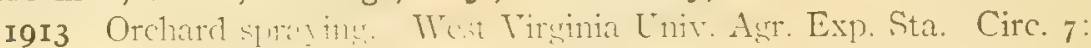
$\mathrm{I}-48$, fig. I-33.

Mention black rot, leaf spot, and canker, and suggest control measures.

\section{Alwood, W. B.}

I892 Brotrus siut. In Fonr likuases of the apple, and treatment of same. Virginia Agr. and Mech. Coll. Agr. Exp. Sta. Bul. $1 ;: 51),(12$.

Describes a leaf disease and uses the rame broran spot. Notes three successive outbreaks in a summer. Questions whether Phyllosticla pirina is the cause.

1893 Injurions incects and rliceases of 1)lants with remedial measures for the same. Virginia Agr, and Mech. Coll. Agr. Exp. Sta. Bul. 24:1-40. Illustrated.

The apple orchards of Virginia said (p. 24) to suffer chiefly from two foliage diseases one of which is called brown spot, attributed to the attachs of Phyllosticia pirina.

I898 a The leaf-sjut liscase of apple. Phyllosticta pirina Sacc, and several unrelated forms occurring therewith. Amer. Assoc. Aclv. Sici. [1" $47:+13$.

Records the following fungi occurring with Phyllosticla pirina Sacc: Sphacropsis Malorum Peck, IIculersunia .1/ali, and an undetermined species.

8 Translated by C. D. Sherbakoff, formerly of the Department of Plant Pathology at Cornell University. 
I898 b On the occurrence of a yeast form in the life cycle of the black rot of apple, Siphaeropisis Malorum Peck. Amer. Assoc. Adv. Sci. Proc. 47:422.

Records the discovery of a yeast form occurring in cultures of this furgus, which on isolation and reinfection on the fruit of apple produced the common fruiting bodies of Sphocropsis Malorum.

I902 Orchard sturlies.- - YV. The bitter rot of apples. Virginia Agr. Exp. Sta. Bul. I $42: 250-274$, pl. I-4.

States (p. 257) that Sphaeropsis Malorum Berk. invades fruit already decaying from the attacks of the bitter rot fungus.

\section{Alwood, W. B., and Price, H. L.}

I902 Orchard sturties.-T'. Report on crah apples. Tirginia Agr. Exp. Sta. Bul. I32:3-I4, fig. I-4.

Note (p. 6) that certain varieties are especially subject to the black rot canker (caused by Spheeropsis Malorum).

Arnaud, G.

I9I2 Notes phytopatholosiques. I. Sphaeropsis psentodiplodia. Montpellier (France) Ecole Nat. d'Agr. Ann. I2:5-17, fig. I-5.

Discusses the fungus as it occurs on several different plants. Notes the variable morphology of the organism and reports the discovery of an ascomycete associated with the pycnidial form. The ascomycete is named Physalospora Cydoniae and is regarded as probably the perfect stage of Sphacropsis pseudodiplodia.

\section{Arthur, J. C.}

I885 Quince rot. In Report of the Botanist. New York (Geneva) Agr. Exp. Sta. Ann. rept. 3:372.

Desirihes sympt ums, anil proves the pathorenuty of the fungus whu he halls sphae. ropsis Cydoniac C. \& E.) on quince fruit.

\section{Baccarini, $\mathbf{P}$.}

I890 Note patologiche. Ital. nuovo giom. bot. 22:64-70.

Reports Sphceropsis Malorum on pears, apples, and peaches in storage. Discusses sclerotia and pycnidial development.

Bailey, L. H.

I907 The healing of mounds. In The gruning-lonok, p. $76-$ I 32 , fig. 68- I I0.

Gives a chapter on the healing of wounds, taking up the nature of wounds, suggestions for the pruner, dressings for wounds, making cuts.

\section{Baldwin, C. H.}

I9r2 Black rot. In Some important diseases of apple. Indiana State Entomologist. Rept. 5:249-252. Illustrated.

Gives notes on black rot, leaf spot, and canker.

I9I4 Black rot (New Iork apple-tree canker and apple leaf spot). In Apjle diseases. Indiana State Entomolosist. Rept. 7 I 50- 52 . Illustrated.

Describes the nature of the injury.

Bary, A. de

1887 Comparative momhology and hiolong of the funcri, Mycetozoa, and bacteria, P. I-525. (Translated by H. E. F. Garnsey and I. B. Balfour.)

Discusses (p. 247) types of pycnidial formation in general. 
Beach, S. A.

Igr2 Black rot. In Spraying practice for orchard and garden. Iowa Agr. Exp. Sta. Bul. 127:50-51. Illustrated.

Black rot observed to occur on some of the summer and early fall varieties.

Beach, S. A., Lowe, V. H., and Stewart, F. C.

I899 Aprle trec canter. Also, Leaf spot. In Common diseases and insects injurious to fruits. New York (Geneva) Agr. Exp. Sta. Bul. I $70: 38_{2}-38_{4}$.

Describe canker, caused by Sphaeropsis Malorum Peck, and leaf spot, due to Phyllosticta spp., with recommendations for control.

Beal, W. J.

I808 Discases of the apple Michigan State Hort. Soc. Ann. rept. 27: $174-18_{3}, \mathrm{pl}$. I-4.

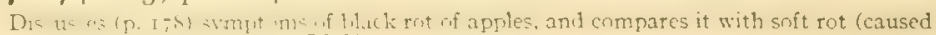
by Penicilliam expansam Link).

\section{Berkeley, M. J.}

I836 Sphacria Malorum. In Hooker's English flora, p. 257-258. Describes the fungus Sphacria Malorum Berk.

I860 Sphaerogsis Malorum B. In Outlines of British fungology, p. 3 6 .

Changes the generic name of the fungus from Sphaeria to Sphaeropsis.

\section{Berlese, A. N., and Voglino, P.}

I886 Macrophoma MIalorum (Berk.) Berl. \& Vogl. Citcd in Saccardo's Syll. Fung. Io: I97. I892. From Veneto-Trentina Soc. Atti. 1886: 184 .

The authors divide the genus Phoma into Macrophoma and Phoma, the basis being the length of the pycnospores; Phoma Malorum (Berk.) Sacc. becoming, as they believe, IIacrophoma Malorum (Berk.) Berl. \& Vogl.

\section{Bethune, C. J. S.}

I909 Funints discasin; and insect pests. Also, Cankers on apple trees. Ontario Agr. Coll. and Exp. Farm. Ann. rept. 34:26-32.

Reports $(p .20)$ that cankers do great damage along the north shore of Lake Ontario. Says (p. 29) that spores of Sphaeropsis Malorum are carried by the wind.

I9ro Black rot cinliut (Sphaeropsis Malorum). Ontario Agr. Coll. and Exp. Farm. Ann. rept. 35:35-36.

States that black rot canker apparently can be successfully controlled by pruning out dead branches, cutting out cankers, and coating the bark with spray.

\section{Bommer, E., and Rousseat, M.}

I885 Florule myenlogique des environs de Bruxelles, p. 3-353.

Sphaeropsis Malorum Berk, is listed (p. 257) on fallen apples.

\section{Brooks, Charles}

I907 Discases of the applc. In Seventeenth and eighteenth annual reports. New Hampshire Coll. Agr. Exp. Sta. Bul. I29: $267270,1) 15$.

Records black rot and cankers due to Sphacropsis Malorum Berk. as common; records leaf spot due to Phylloslicla pirina Sacc. and $P$. limilata Peck as serious. with little or no effect on it from spraying. States that majority of apple limb cankers are caused by Sphacropsis Malorum Berk., and that few of the orchards visited did not show the disease. 
I909 Black rot, canlier, and leaf spot. In Some apple diseases. New Hampshire Agr. Exp. Sta. Bul. I44: I23-I 26, fig. 20-24.

Discusses occurrence, symptoms, etiology, and control of black rot, canker, and leaf spot. Lists the following fungi as associated with these diseases: Sphaeropsis Malorum, Coniolhyrium pirinc, Coryneum folicolum, Allernaria sp., and one of the
Tuberculariae.

I9I2 a Black rot, canker, and leaf spot. In Some apnle diseases and their treatment. New Hampshire Agr. Exp. Sta. Bul. I $57:$ I $7-20$, fig. $20-24$.

Maintains that black rot does considerable damage in storage. Outlines sprayings which are said to be fairly effective for leaf spot.

I912 b Funciciles in the apple orchard. New Hampshire Agr. Exp. Sta. Bul. I6I: I-I5.

Compares different fungicides for control of leaf spot.

\section{Brooks, Charles, and DeMeritt, Margaret}

I9I2 Apple leaf spot. Phytopath. 2: I8I-I9o, pl. I7, fig. I-6.

Give an account of the etiology of leaf spot, paying particular attention to the morphological and biological variations in Sphaeropsis Molorum. Infection shown to occur from the time the leaves unfold until the last of August. Cultivation, spraying, and the removal of cankers given as the important control measures.

\section{Brooks, Charles, Fisher, D. F., and Cooley, J. S.}

I9I4 Apple rots. Phytopath. 4:403. (Abstract.)

List several species of fungi, including Sphaeropsis Malorum, which were isolated from market and storage apples.

\section{Bryce, P. I.}

I9I5 Apple leaf-spot or black rot canker. Quebec Soc. Prot. Plants from Ins. and Fung. Dis. Ann. rept. 7:86-90. Illustrated.

Gives an account of symptoms, varietal susceptibility, and control of the disease.

\section{Bubák, Fr.}

I909 Ein kiner Buitrag zur Pilzfora von Nicderosterreich. Ann. myc. $7: 59-62$.

Sphacropsis Mali (West.) Sacc. listed (p.62) as collected on Pirus MIalus in "Hohe Warte" bei Wien.

\section{Burrill, T. J.}

I907 Bitter rot of apples: botanical investigations. Illinois Univ. Agr. Exp. Sta. Bul. I $8: 553-608$.

States that Sphaeropsis Malorum is sometimes associated with the bitter rot fungus in cankers. The former organism said to follow the latter under Illinois conditions.

Burrill, T. J., and Blair, J. C.

Igor Apple fruit-rots. Illinnis ['niv. Agrr. Exp. Sta. Circ. $37:$ I $_{2}$ pages, unnumbered). Illustrated.

Special attention given to symptoms of black rot, caused by Sphaeropsis Malorum. Suggestion that another specics causes canker. Discussion on second and third pages.

\section{Butler, O.}

I9I2 Report of the Department of Botany. In Twenty-third and twenty-fourth rejorts. New Hampshire Agr. Exp. Sta. Bul. I6 $6: 16-17$.

Mentions the work of Brooks, which appeared later in Phytopathology 2 :I8I-190 and was published jointly by Brooks and DeMeritt. 


\section{Caesar, $\mathbf{L}$.}

1909 Black rot canker of apple trees. In Lime-sulphur wash. Part II.- Practical and popular treatment. Ontario Agr. Dept. Bul. I77:59-6I, fig. I6.

States that on leaves and fruit the disease is seldom serious, but cankers often do great damage especially in Prince Edward County, Ontario.

I9I2 Black rot canker. In Our most troublesome orchard insects and diseases. Ontario Fruit Growers' Assoc. Ann. rept. $44: 22$, fig. I 5 .

Author is convinced that the fungus follows winter injury.

\section{Card, F. W.}

I897 Notes on pruning. Nebraska Agr. Exp. Sta. Bul. 50: I-Io.

Concludes from experiments that lead paint is the best material for covering wounds; grafting wax said to be the next best; coal tar found to prevent checking, but seemed to hinder the healing process; pine tar and shellac reported as unsatisfactory.

\section{Chase, W. W.}

I9I3 Aiplle leaf spot. In Principal insects and diseases of the apple in Georgia. Georgia State Bd. Ent. Bul. 38:40-4i, pl. 6, fig. 2 .

Leaf spot caused by Sphacropsis Malorum said to be one of the most destructive apple foliage diseases in Georgia.

\section{Chester, F. D.}

I90 a Canker in apple and pear. In Pear blight and pear canker. Delaware Coll. Agr. Exp. Sta. Bul. 52:6-8, fig. 4-7. States that twigs and branches bearing pycnidia of Sphacropsis Malorum Peck are sources of infection.

I90I b Canker in the apple and pear. In Report of the Mycologist. Delaware Coll. Agr. Exp. Sta. Ann. rept. I2: 43-46, fig. 4-7. (Same as Ig0I a.)

I902 Pear canker treatment. Also, Canker in apples. In Sundry notes on plant diseases. Delaware Coll. Agr. Exp. Sta. Bul. 57:8-II, fig. 5-6.

Describes symptoms and control of canker of pear and apple caused by Sphaeropsis Malorum.

\section{Clement, F. M.}

I9I3 Winter injury in orchards. Quebec Soc. Prot. Plants from Ins. and Fung. Dis. Ann. rept. 5:24-26.

Says that frost wounds are made doubly serious if not treated to prevent the admission of the spores of saprophytic fungi, especially those of the black rot fungus, with the consequent development of apple canker.

\section{Clinton, G. P.}

I902 Black rot, Sphaeropsis Malorum Berk. In Apple rots in Illinois. Illinois Univ. Agr. Exp. Sta. Bul. 69:192-r93, pl. B, fig. 2.

Sphaeropsis Malorum Berk. regarded as one of the chief causes of rotting of apples in market.

1904 Black rot, Sphacropsis Malorum Pk. In Report of the Botanist. Connecticut (New Haven) Agr. Exp. Sta. Ann. rept. 27:298, 342,352 , pl. I I, a.

Black rot regarded as one of the commonest and most universal diseases of the apple. Noted also on pear and quince. 
1907 Winter injury and canker, sinhaeropsis Malorum Pl. In Rerome of the Botanist for Igo6. Connecticut (New Haven) Agr. Exp. Sta. Ann. rept. 30:310-3II, pl. I 7, a.

A peculiar limb disease of the apple is doubtfully attributed to winter injury and Sphaeropsis Malormm.

rgis Notes on plint discases of Connecticut. In Report of the Botanist for I9I3. Connecticut (New Haven) Agr. Exp. Sta. Ann. rept. 38 (I9I4):I-29. Illustrated.

Black rot noted on stored apples (p. 5).

Clinton, G. P., and Britton, W. E.

I9ro Black rot, Sphaterusis Malorum. In Tests of stummer sjorays on apples and peaches in rgro. Connecticut (New Haven) A gr. Exp. Sta. Ann rept. 33-34:590, pl. 21, b.

Authors report occurrence of black rot (due to Sphocropsis Malorum) on summer and stored winter varieties. State that the use of insecticides in keeping out codling moth lessens the rot starting from this cause.

\section{Cook, M. T.}

I9I3 Report of the Plant Pathologist. New Jersey Am. Exp. Sita. Ann. rept. 33:509-527.

Black rot of apple and quince, caused by Sphacropsis Malorum, among the diseases listed (p. 5I2) as most important and most common in the nurseries.

I9I4 a Black rot of the arple and quince. In Some discases of nursery stock. New Jersey Agr. Exp. Sta. Circ. 35:13-14, fig. 9. Twig and leaf-spot forms of the disease very common in nurseries. It is advised that diseased trees should never be set.

I9I4 b Black rot (Siphacropsis Malorme Pli.). In Must common diseases of the year. New Jersey Agr. Exp. Sta. Ann. rept. 34: 799,809 .

Black rot of apples most severe nn Red Astrachan. Star, Lawver, Smokehouse. Black rot of quince reported as being very abundant and very severe.

Cooke, M. C.

I892 Silhamplesis pomorum (Schwz.). In Sihnacriaceac imperfectac cognitae. Grevillea 20:86.

Suggests that Sphacropsis pomorum (Schwz.) [= Sphaeria pomorum Schwz.] is probably the same as Sphaeropsis Malorum Peck, of which Phoma Molorum Berk., erected by Saccardo, is possibly a younger condition.

\section{Cooper, J. R.}

I9I3 The control of canker in the orchard. Nebraska hort. 3:2: I 2. Black rot canker is ranked third in importance among cankers in Nebraska. The discussion of control measures is directed at the Illinois blister canker.

\section{Corbett, L. C.}

I9oo Brown spot, fros eye. In Fruit diseases and how to treat them. West Virginia Agr. Exp. Sta. Bul. 66:202-204, fig. 2.

Author considers frog-eye, or brown spot (said to be due to Phyllosticia pirina), more injurious than either blight or scab. 
Crabill, C. H.

I9I5 The frog-eyc leaf spot of apples. Tirginia Agr. Exp. Sta. Bul. $209: 3-16$, fig. I-5.

Author states that frog-eye leaf spot is the most prevalent of apple foliage diseases in Virginia. The annual losses from the disease are said to be heavy in that State, but systematic spraying has controlled the disease in a satisfactory and effective manner. Symptoms are described. Etiological studies are tabulated, and from his experiments the author concludes that frog-eye spots are initiated by Spheeropsis Malorum. All other fungi with which he deals are classed as facultative parasites, following $S$. Malorum, or as pure saprophytes.

Cummings, M. B.

I909 Apple orchard survey of Niagara County. Cornell Univ. Agr. Exp. Sta. Bul. 262:277-320, fig. 26-40.

Gives notes (p. 304, table 12) on economic importance of canker.

Dandeno, J. B.

I906 A stimulus to the production of cellulose and starch. Michigan Acad. Sci. Rept. 8:40-44.

Claims that the fungus Sphoeropsis Molorum stimulates the cells of ripe apple fruit to form starch and to thicken the cellulose walls. Suggests that starch is built up first and then dissnlved and built into cellulose, the process going on until the fruit is mummified and dry, whereupon it is in a state of preservation.

\section{Delacroix, G.}

I903 a Sur un chancte du pommier produit par le Sphaeropsis Malorum Peck. Soc. Myc. France. Bul. 19: I32-r40. Illustrated.

Gives an account of the disease which, it is believed, appeared in France at least as early as I90I. Discusses the morphology of the parasite and the relationship of the mycelium to the tissues of limbs, mentions moculation experiments, and suggests control measures.

I903 b Sur l'identité réelle Sphacropsis Malormm Peck. Soc. Mrce. France. Bul. i9: 350-352.

Reports the examination of the following type material: Sphaeropsis Malorum Peck 5. Malorum Berk. Diplodia maura Cooke \& Ellis, D. pseudodiplodia Fckl., and Bolryodiplodia Mali P. Brumaud. Concludes that $S$, Malorum, $D$, meuro, and $B$. Mali are all different, and that S. Malorum in France, S. Malorum Peck, and D.

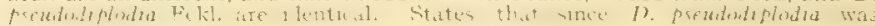
described before $\$$. Malorum, the latter name should disappear, and the new combination S.pseudodiplodia (Fckl.) G. Del. is proposed.

\section{Dickens, A., and Headlee, T. J.}

IgI I Spraying the apple orchard. Kansas Agr. Exp. Sta. Bul. $174: 251$ 202, fig. I-10.

Give an account of experimental work in the control of black rot by spraying. Bordeaux mixture and lime-sulfur were used on several varieties.

\section{Douglass, B. W.}

19го Black rot. In Plant discases. Indiana State Entomologist. Rept. 2 (I 908-I 909): I35.

The disease is briefly described.

\section{Duggar, B. M.}

I909 Black rot and canker of pomaceous fruits. In Fungous diseases of plants, p. 303, 350-354, fig. I69-172.

A discussion of habitat relations, etiology, and control of the fungus. 


\section{Edgerton, C. W.}

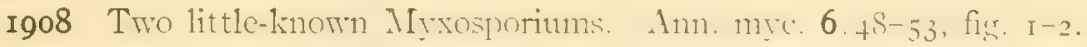

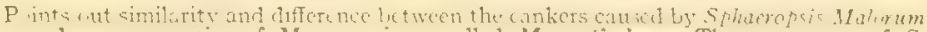
and a new species of Mysosporium, called $M$. corticolum. The synonymy of $S$. Ifolorum is given.

\section{Ellis, J. B.}

I880 On the rariability of Sphaeria Ouercurm Schm. Philartelphia Acad. Nat. Sci. Proc. I879:66-70.

Author would include several enumerated species of Sphaeria, Botryosphaeria, Dothidea, and Melogramma under one species, and the name Melogramma fulieinosa is accepted. Ascigerous forms accompanied by stylospore forms of the Diplodia or Sphaeropsis type.

Ellis, J. B., and Everhart, B. M.

I892 The North American Pyrenomycetes, p. I-793, pl. I-4I.

\section{Eustace, H. J.}

1908 Investigations on some fruit diseases. New Tork (Crenceal) Agr. Exp. Sta. Bul. 297:29-48, pl. I-7.

Shows by experiment that the fungus (Sphoeropsis $M$ falorum) is not destroyed but iis growth is retarded in storage at temperatures ranging from $29^{\circ}$ to $32^{\circ} \mathrm{F}$. Gives results of sulfur fumigation in storage.

\section{Evans, I. B. P.}

igro The Nerr Tork apple tree canlier or hlack rot fungus in South Africa. Transvaal agr. journ. 7:62-64, pl. 7 .

Calls attention of South African growers to the presence of "another imported fungus, and one which it will not be well to neglect."

Faurot, F. W.

I903 Black rot. In Report of fungous discases occurring on cultivated fruits during the season of 1902. Missouri State Fruit Ex1. Sta. Bul. 6:6-7.

The name blossom rot is employed for calyx-end infections on apples. Symptoms are described.

I9I2 Black rot. In Common orchard troubles, spray mixtures, and spray calendar. Missouri State Fruit Exp. Sta. Bul. 23: I4-I 5 , fig. 8-9.

States that black rot, also called blossom-end rot, occurs largely on fruits of which the skin has been broken, and that owing to the habits of the fungus it is not controlled by spraying.

\section{Floyd, Bayard F.}

I905 Apple canter. Black rot. In Some common fungous diceases and their treatment. Missouri State Hort. Soc. Ann. rept. $48: 432$.

Notes that windfall apples are very susceptible.

Freeman, E. M.

I905 Blact rnt of apple (Sphaeropsis Malorme Peck). In Minnesota plant diseases, p. $36_{3}-364$, fig. I94.

Gives a short general account of black rot, leaf spot, and canker. 
Fückel, L.

I869 Symbolae mycologicae, p. I-459, pl. I-6.

Descriptions of Diplodia pseudodiplodia Fckl. (p. 393) and Diplodia Malorum Fckl. (p. 395).

\section{Galloway, B. T.}

1892 Report on the experiments made in IS9I in the treatment of plant diseases. U. S. Agr. Dept., Veg. Path. Div. Bul. 3: I76. Illustrated.

Gives (p. 39) an account of petal and young fruit infection induced by Sphaeropsis Malorum.

\section{Garman, H.}

1895 Spraying experiments in rSo5. Kentucky Agr. Exp. Sta. Bul. 59:III-I29. Illustrated.

Sphacropsis Malorum said (p. 127) to be the cause of most of the fruit rot in the State.

I908 Brown rot of apples. In I. Spraying apple trees. 2. Apple orchard pests in Kentucky. Kentucky Agr. Exp. Sta. Bul. 1 $33: 9,65-66$.

The disease on apple fruit (due to Sphaeropsis Malorum) is called brown rot, and spraying experiments for the control of the disease are reported.

Giddings, N. J.

I908 Apple canker. In The occurrence of plant discases in ino7. Vermont Agr. Exp. Sta. Ann. rept. 20:33r.

Apple canker, caused by Sphaeropsis Malorum, said to be rather prevalent in some orchards. The statement is made that the disease is easily controlled by pruning and spraying, and is thus kept down in most well-tended orchards.

Green, W. J., Selby, A. D., and Gossard, H. A.

I9I5 Spraying prostam for orchards with combinations recommended. Ohio Agr. Exp. Sta. Circ. I49:53-60.

Suggest (p. 54-55) a combination of insecticide and sungicide for control of codling moth, apple scab, and black rot.

Griffon, E., and Maublanc, A.

Igro Sur des especes de Sphaeropsis et de Diplodia parasites du poirier et du pommier. Soc. Myc. France. Bul. 26:307-316. Illustrated.

Discuss symptoms, and several species of fungi on apple and pear. The conclusion is reached that these trees may be attacked by Sphaeropsis and Diplodia, which act as wound parasites. The species involved are regarded as distinct and are briefly described; these are Sphaerotsis Malorum Peck, Sphaeropsis pseudadipladia (Fckl.) Del., and an undetermined Diplodia.

\section{Güssow, H. T.}

I9I I Black rot (Sphacropsis Malorum Peck.). In Report of the Dominion Butanist. Experimental Farms (Canada). Rept. I9I I: $246-247$.

Discusses symptoms and control. 
Halsted, B. D.

I892 The black rot of the quince. In Some fungous diseases of the quince fruit. New Jersey Agr. Coll. Exp. Sta. Bul. 91:8-10, fig. 5-6.

Concludes from observation and experiment that the species of Sphaeropsis on quince, apple, and pear are the same. States that the fungus causes one of the most destructive decays of the quince, and that the spores pass through the air or are carried by insects.

I894 Decars of mature apples. In Report of the Botanist. New Jersey Agr. Exp. Sta. Ann. rept. I4:367-377, fig. 35-4I.

Symptoms of black rot well described (p. 374-375). Author makes the point that the

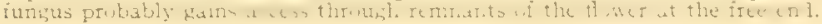

\section{Harrison, Charles}

I823 A treatise on the culture ank manawement of iruit trees, p. I 3,56. Illustrated.

Attributes (p. 34I-343) canker to such causes as injudicious pruning, bruising, nailing, bad subsoll. Surgical methods recommended.

\section{Hartig, R.}

I894 Text-bonk of the disease's of trees, p) I-331. (Tranilated by Somerville and Ward.)

\section{Hartley, C. P.}

I908 a Some apple leaf-spot fungi. Science n. S. 27: 2 I2

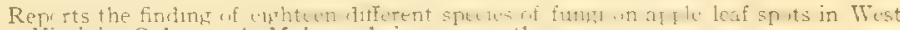
Virginia, Sphaeropsis Malorum being among the common ones.

I908 b Some apple leaf-spot funci. Science 11. S. 28: I57 159.

Gives brief historical review of the question of the etiology of apple leaf spot. A list of several species of fungi found on spotted leaves is given, and inoculation experiments with certain of these are reported. Results indicate that Coniolhyrium pirind is a wound parasite, while Coryneum foliicolum appeared to be even less parasitic.

1913 Twig canker on black birch. Phytopath. 3:248-249.

Reports the isolation of a Sphaeropsis, closely resembling S. Molorum but with somewhat smaller spores, from swollen cankered black birch twigs (Betula lenta L.) Inoculation experiments show that the organism is parasitic only under certain conditions, nor is it regarded as the cause of the swollen carkers.

\section{Heald, F. D.}

I906 The black-rot o apples due to Sclerotinia inutisena. Nuhaska Agr. Exp. Sta. Ann. rept. I9: 82-9r. Illustrated. (See also p. 22, 6r.)

Points out that the term black rol is a confused one, having been used for diseases causer by both Monilia and Sphaeropsis. The two diseases are compared and contrasted as to symptoms.

\section{Hedges, Florence, and Tenny, L. S.}

I912 A knot of citrus trees caused by Sphacropsis tumefaciens. U. S. Plant Indus. Bur. Bul, 247:I-74. Illustrated.

\section{Hesler, L. R.}

I9I2 The New York apple tree canker. Indinun Acarl. Sci. Proc. I9I I : $325-339$, fig. I -7 .

Gives data concerning the geographical distribution, importance, symptoms, etiology. and control of the disease. The synonymy of the fungus is reviewed. 
I9I3 Physalospora Cydoniae. Phytopath. 3: 290-295. Illustrated. Proves experimentally the genetic connection between Physalospora Cydoniae and Sphaeropsis Malorum.

I9I4 Biological strains of Sphaeropsis Malorum. Phytopath. 4:45.

Results of cross-inoculation work with the fungus from several host plants indicate that there is one large morphological species embracing many biological races.

\section{Hewitt, J. L., and Hayhurst, P.}

I9I I Diseases of apple trees and fruit caused by fungi and insects. Arkansas Agr. Exp. Sta. Bul. Iog:409-445.

Note the occurrence of black rot and leaf spot in Arkansas (p. 438, 440-44I).

\section{Howitt, I. E.}

I913 Fungus diseases. Ontario Agr. Coll. and Exp. Farm. Ann. rept. 38:29-30.

Notes the occurrence of black rot canker along with other plant diseases.

\section{Ingram, Della}

I9r2 Preliminary notes on a twig blight of Quercus prinus. Phytopath. 2: $96-97$.

Mentions an apparently serious disease of the chestnut oak which occurs in Connecticut. Virginia, Maryland, and Pennsylvania. The organism associated with the disease is said to agree with Dolhiorella quercina (C. \& Ell.). (Cf. Rankin, W. H., I9I4, p. I4I.)

Jehle, R. A.

I9I3 The brown rot canker of the peach. Phytopath. 3:105-110, pl. Io, fig. I- -5 .

Reports successful use of coal tar on wounds of peaches.

\section{Jones, L. R., and Giddings, N. J.}

1907 Apple canker. In The occurrence of plant diseases in Vermont in I906. Vermont Agr. Exp. Sta. Ann. rept. I9: 23 I-232.

The fungus Sphaeropsis Malorum said to continue its destructive invasion and to be the cause of every case of apple canker examined.

\section{Kern, F. D.}

I906 Indiana plant discases in 1905. Purdue Univ. Agr. Exp. Sta. Bul. III:I2I-I34.

Black rot of the apple, pear, and quince reported (p. 125) from the southern part of the State only.

Ig07 Indiana plant diseases in I 906. Purdue Univ. Agr. Exp. Sta. Bul. I I $9: 425^{-436 .}$

Mentions (p. 428) black rot and canker of the apple, and black rot of quince, present to some extent in the southerm part of the State.

\section{Kinney, L. F.}

I895 a Some special orchard treatment of the apple, pear, and quince. Rhode Island Agr. Exp. Sta. Bul. 3I: I-I 7, fig. I-9.

Reports ( $\Gamma$. I0) failure to control black rot of quince by sprasing.

I895 b The leaf spot of the apple and pear. I $"$ Horticultural Division. Rhode Island Agr. Exp. Sta. Ann. rept. 7: I88-I89, fig. 7-8.

Points out resemblance of injury by apple leaf miner (Tischeria malifoliella Clemens) to apple leaf spot. Spots on the leaves, and spores of Phyllosticla pirina, which is regarded as the cause, are figured. 
I895 c The hrown rot. In Horticultural Division. Rhode Island Agr. Exp. Sta. Ann. rept. 7:192-I93, fig. I2.

Symptoms are given. The disease on the fruit (which author calls brown rot) and spores of the fungus are figured.

\section{Kirchner, Oskar}

I906 Dic Krankheitern unł Beschärligungen unserer landwirtschaftlichen Kulturpflanzen, p. I-647.

States (p. 440) that the canker disease of apple trees, caused by Diplodia pseudodiplodia Thum., occurs in North America, France, and perhaps Germany.

\section{Lamson, H. H.}

I897 Depa:tment of Bacteriolong. In Ninth annual report. New Hampshire Coll. Agr. Exp. Sta. Bul. 48: I $46-$ I 47.

Bordeaux mixture said to have had little effect in controlling leaf spot due to Phyllosticta pirina; hence work was directed toward its control.

I899 Apple discalses. In Note's on apple and potato discasces. New Hampshire Coll. Agr. Exp. Sta. Bul. 65: 106-107, fig. 38-39. Notes the serious nature of leaf spot. which is said to be caused partly at least by l'hyllosticla pirina.

I9or Aplle tree canker. In Thirtenth annual report. New Hampshire Coll. Agr. Exp. Sta. Bul. 87: I30.

Reports the presence of a canker which is believed to be caused by a fungus.

1902 The cold storage of apples. - Part II. Influence of cold storage on the decay of apples. Effect of wrapping apples in paper. New Hampshire Coll. Agr. Exp. Sta. Bul. 93:75-8 I, fig. I.

Sphacropsis Malorum listed ( $p, 75$ ) as one of three fungi which cause most of the rotting. Author concludes (p.8I) that a temperature of $31^{\circ} \mathrm{F}$. is more effective than $40^{\circ}$ to $45^{\circ} \mathrm{F}$, and that wrapping the fruit is of decided advantage in extending the keeping period beyond the first of June. Clean newspaper said (p. $8 \mathrm{I}$ ) to be just as effective as more expensive paper.

1903 Leaf spot. In Fungous diseases and spraying. New Hampshire Coll. Agr. Exp. Sta. Bul. ior:6r-62. Illustrated.

Bordeaux mixture said to have little effect in controlling leaf spot of apple.

\section{Lewis, C. E.}

r909 Apple diseases caused by Coryneum foliicolum and Phoma Mali. Maine Agr. Exp. Sta. Bul. I70:I83-200, fig. I 7-42. Reports successful infection experiments with Sphaeropsis Malorum Peck on injured bark and on uninjured apple leaves.

I9I2 Inoculation experiments with funwi associated with apple leaf spot and canker. Phytopath. 2:49-62.

An account of experiments directed toward the determination of the parasitism of such fungi as Sphacropsis Malorum. Phyllosticla limilala Peck, Coniolhyrium pirina (Sacc.) Sheldon, and Coryneum foliticolum Fck1. Author concludes that a part of the leaf spot in Maine is due to Sphoeropsis. Malorum, but that a similar spotting is due to bordeaux mixture; that Sphaeropsis Molorum is the only fungus isolated from apple leaves in the State which causes spots when inoculations are made from pure cultures; and that, of the several fungi studied, this fungus does the greatest damage to branches and to twigs.

\section{Lewis, I. M.}

I908 Aple leaf siput. Nuw Hamphire Asr. Exp. Sta Ann rept. I9-20:365-369, 1) 8. 8-9.

Gives a historical review of the causal nature of the discase, and presents inoculation and control data. 


\section{Lochhead, William}

I905 Black rot canker. Ontario Agr. Coll. and Exp. Farm. Ann. rept. 30:49, fig. 4-5.

Defines the term conker and outlines control measures.

I909 Apple diseases. In Fungous diseases in Quebec in rgos. Quebec Soc. Prot. Plants from Ins. and Fung. Dis. Ann. rept. I:3I.

The prevalence of the canker form of this disease is roted.

Longyear, B. O.

I904 Fungous diseases of fruits in Michigan. Michigan State Agr. Coll. Exp. Sta. Spec. bul. 25: $\mathrm{x}-68$, fig. $\mathrm{I}-42$.

Records the black rot disease of apple (p, IO-I3), pear (, 10$)$, and quince $(p, 20)$.

\section{Lunge, George}

I909 Coal tar and ammonia, Part I, chap. $x$, p. I-I5.

Notes differences in tars, both physical and chemical, depending on the origin. Tar obtained from the same material also differs very much in composition, according to the temperature of the dry distillation, and even according to the shape of the retorts.

McAlpine, D.

I902 Fungrus diseases of stone-fruit trees in Australia and their treatment, p. I-165. Illustrated.

Lists (p. 133. 134) Diplodia Malorum on peach and plum twigs.

\section{M'Cormack, Edna F.}

I9I0 Black rot of the apple. In Fungous diseases of the apple. Indiana State Entomologist. Rept. 3:I42-I44. Illustrated. Symptoms discussed.

\section{McCready, S. B:}

I910 Black rot canker (Sphaeropsis Malorum Peck). Ontario Agr. Coll. and Exp. Farm. Ann. rept. 35: $41^{-42}$.

Brief reference to hosts, distribution, etiology, and control.

IgrI Black rot of apple. Ontario Agr. Coll. and Exp. Farm. Ann. rept. $36: 37$

Reports use of lead paint and gas tar as wound dressings; the latter found to give better protection.

\section{Mangin, L.}

Igor Sur une nouvelle maladie des pommiers causée par le "Diplodia pseudo-diplodia." Journ. agr. prat. n. S. 2: I38-I39.

Reports accurrence of the disease on apple branches in France, and gives suggestions for control.

Morse, W. J.

I909 Notes on plant discases, I00\$. Maine Agr. Exp. Sta. Bul. I64: I-28. Illustrated.

States (p. 3-4) that Sphacropsis Malorum from leaf spot produced decay of fruit as a result of artificial inoculation. States (p. ro) that self-boiled lime-sulfur seemed effective in controlling leaf spot. 
Morse, W. J., and Lewis, C. E.

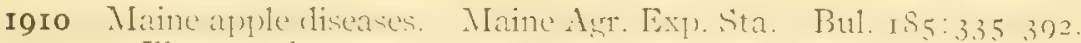
Illustrated.

Notes on the etiology of leaf spot and canker. Canker fungus in Maine orchards follows frost injury.

Munson, W. M.

I909 Apple cnemies, and how to fight them. Trest Tirginia Lniv Agr. Exp. Sta. Bul. I2 I:353-366.

Control measures for leaf spot and canker given (p. 360-362).

Norton, J. B. S., and Symons, T. B.

I907 Black-rot (Sphacropsis MIalomm). In Control of insect pests and diseases of Maryland crops. Maryland Agr. Exp. Sta. Bul. I I $5: 178$.

Give brief recommendations for the control of black rot, leaf spot, and canker.

O'Gara, P. J.

I902 Notes on canker and black-rot. Science n. S. 16: 434-435.

Notes a case of girdling of branches of sumac (Rhus glabra L.) by Sphaeropsis rhoina (Schw.) Starb.. which fungus, after careful cultural and inoculation experiments, is regarded as probably identical with Sphacropsis Malorum.

Orton, C. R.

I9I4 Black tot. In Some orchard diseases and their treatment. Pennsylvania State Hort. Assoc. Proc. 55: 43-56. Illustrated.

Author states that Sphaeropsis Malorum rarely if ever produces cankers on its own initiative. He notes its wide occurrence on various plants, and says that a perfect stage has recently been found on apple, quince, oak, grape, witch-hazel, and other hosts.

Orton, W. A.

r9o2-1907 Plant discases in the Enited Stat's in roor-190\%. L. S. Agr. Dept. Yearbook 1901:669; I902:715; I903:550; I904: $5 \delta_{2}-5 \delta_{3} ; 1905: 603-604 ; 1906: 499-500$; 1907: 577 579.

Gives notes on the occurrence and destructiveness of black rot, leaf spot, and canker of apple, pear, and quince.

\section{Paddock, Wendell}

I898 a An apple canker. Science n. S. 8:595-596.

Reports preliminary experiments in canker investigation. Cultures of fungi from cankers showed Schizophyllum commune, and a dark-spored fungus which is said to resemble Sphaeropsis Malorum Peck.

$\mathbf{r} 898$ be Additional notes on an apple cantier. Science n. $5.8: 8_{3} 6-837$. Suggests that Sphacropsis Malorum Peck is parasitic on the wood of pear and quince as well as on that of apple. Cross-inoculations of the fruits of these three plants gave positive results.

1899 a An apple canlier. Western New Tork Hort. Soc. Proc. 44: 58-63. Illustrated.

(See I $899 \mathrm{~b}$, of which this is a popular presentation.)

I899 b The New Tork apple-tree canker. New York (Genera) Agr. Exp. Sta. Bul. I63:177-206, pl. I 0.

Contains an account of host relationships, names of the disease, symptoms, etiology, and control. Presents conclusive data proving that Sphacropsis Malorum is the cause of canker on apple; considerable data indicate that this species of Sphaeropsis also occurs on many other plants. 
I9oo The New York apple-tree canker (Second report). New York (Geneva) Agr. Exp. Sta. Bul. I85:203-2 I3, pl. I-4.

States that Sphaeropsis Malorum occurs on apple, pear, and quince fruits, and on apple, pear, and hawthorn trees; and that it probably occurs on several other plants, but experiments are nut regardid as warranting this as a definite conclusinm. Nutes that apple leaves are occasionally attacked by a Sphaeropsis.

\section{Parkinson, John}

1629 Paradisi in sole paradisus terrestris, p. I-612. Illustrated.

Briefly outlines (p. 550) the nature and control of canker. Of historical importance.

\section{Parrot, P. J., and Fulton, B. B.}

1913 Notes on treecrickets. Journ. econ. ent. 6:177-ISo. Iilustrated.

Note that the penetration of apple bark tissues by the ovipositor of the tree cricket is apparently attended by an infection of some unknown fungus or bacterum, which results in the formation of a canker indistinguishable in its appearance and effects from the New York apple tree canker or the fire blight canker.

I9I4 Tree crickets injurious to orchard and garden fruits. New York (Geneva) Agr. Exp. Sta. Bul. 388:4 I5-46I. Illustrated.

Authors note (p. 4.42) that injuries by tree crickets are followed by some infectious agent. and that these lesions, in their external appearances and their effects, resemble superficially certain stages of the New York apple tree canker caused by Sphoeropsis Molorum.

Peck, C. H.

I879 Report of the Botanist. New York State Mus. Nat. Hist. Ann. rept. 3I: I9-6o.

Reports (p. 20-2r) the discovery of Sphaeropsis Malorum on apple fruits in Schoharie

188r Report of the Botanist. New York State Mus. Nat. Hist. Ann. rept. $34: 24-58$, pl. I-4.

Describes ( $p .36$ ) symptoms of black rot, and points out the fact that the distinction between Sphaeropsis and Diplodia sometimes fails, since both one- and two-celled spores are found in the same spore case.

\section{Pollock, J. B., and Kauffman, C. H.}

I905 Michigan fungi. Michigan Acad. Sci. Rept. 7:57-6\%. List Sphaeropsis Mali (West.) Sacc, and S. Malorum Peck.

\section{Potebnia, A.}

I907 Mycologische Studien. An11. myc. 5: I -2S, pl. I-3, fig. I- +3 .

Discusses mycelial development, including spore germination and protoplasmic streaming.

rgто Beiträge zur Micromycetenflora Mittel-Ruszlands. Ann. mỹc. 8: $42-93$, fig. I-38.

States that the pycridia of $S$. psendodiplodia (Fckl.) Del. arise meristogenetically.

I9 2 Pilzliche simmlionten. 2. Sphaeropsis und Heliconnces, 1). 28. Illustrated. (Separate sent by Potebnia to the writer.)

\section{Price, H. L.}

I909 Black rot. In Fighting the ineect pests and cliseases of orchard, field, and garden crops. Virginia Agr. Exp. Sta. Circ. 7: IO-II, fig. 2 .

Recommendations for the control of black rot, leaf spot, and canker. 
Quaintance, A. L., and Scott, W. M.

Igr2 Aple leaf-spot. In The more inportant insect and fungous enemies of the fruit and foliage of the apple. U. S. Agr. Dept. Farmers' bul. 492:35-36, fig. 20 .

Discuss the importance, symptoms, etiology, and control of apple leaf spot caused by Sphaeropsis Malorum.

Rankin, W. H.

I9I4 Sphateropis canker of Quercus prinus. Plytopath $4+4+5$.

Reports Sphaeropsis Malorum Berk. as causing twig and limb cankers on chestnut oak (Quercus prinus L.), the account being based on observation and inoculation experiments. Regards the disease as the one described by Miss Della Ingram in Phytopathology 2:96 (p. 136).

\section{Reddick, Donald}

1912 Frost injury. New York State Fruit Growers' Assoc. Proc. I I : $34-4$, fig. I-2.

Sphaeropsis Malorum said to be usually found following frost injury.

\section{Reed, H. S.}

I908 Fall hlossoming of the aprle induced ly the black rot. Plant world II : $256-257$.

Notes a case in which Sphacropsis Malorum inhibited the normal activities of an apple tree, allowing the tissues to carry on the growth which would normally have been deferred for several months, and resulting in the unfolding of normal blossoms on October 5 .

\section{Reed, H. S., and Cooley, J. S.}

I9I I Black rot (Sphaeropsis Malorum). In Plant discases in Vircinia in the years 1909 and I9Io. Virginia (Polytech. Inst.) Agr. Exp. Sta. Ann. rept. I909-1910: 102-IO3, fig. 2 I.

Record black rot, leaf spot, and canker. Report pycnospores discharging from pycnidia on leaves at Blacksburg on June 25. I910.

Reed, H. S., Cooley, J. S., and Rogers, J. T.

I912 Foliage (lisease: of the apple. Tirginia (Polytuch. Inst.) Arr. Exis. Sta. Bul. 195: I-24, fix. I 13

Give points concerning the varietal susceptibility of apples; the distribution, importance, and symptoms of the disease; and the life history of the fungus.

\section{Reed, H. S., and Crabill, C. H.}

I9I3 Black rot (Sphnteropsis Malonum). In Plant discases in Virginia in the years IgII and r9I2. Virginia (Polytech. Inst.) Agr. Exp. Sta. Ann. rept. I9II-I9I2:36, fig. 3 .

Note that Sphacropsis Malorum accurs on twigs previously killed by the fire blight organism. Figure a multilocular sterile (?) pycnidium.

Reed, H. S., and Stahl, H. S.

I9I I The erepsins of Glomerella rufometulans and Siphacropsis

Malorum. Journ. biol. chem. I0: I09-II2.

Authors find evidence of erepsin produced in pure cultures.

\section{Roberts, J. W.}

I9I3 The "rough-bark" disease of the Yellow Newtown app"e. U. S. Plant Indus. Bur. Bul, $280: I-I 5, \mathrm{pl} . \mathrm{I}-3$.

Reports (p. 9, I5) Phomopsis Mali, a new species, associated with Sphaeropsis Malorum on leaf spots. 
Igr4 E:periments with apple leaf-spot fungi. Joumi agr. research 2: $57-66$, pl. 7, fig. $1-3$.

Reports the isclation of sc*eral epecies, including Sphueropis Malurm, from apple le f spots. A new species, Alernaria Mali, is in the list and is technically described. From experiments conducted it is concluded that this species may be classed as a rather strong facultative parasite.

Rose, D. H.

I9I4 Ring rot. Also, Black rot (Sphacopsis Malormm). In Biennial report. Missouri State Fruit Exp. Sta. Bul. 24 (Bienn. rept. I9I3-I9I4): 20, 23-24, pl. 5, fig. I-2.

Ring rot. or blossom-end rot, of the apple fruit thought to be due to frost injury at blossoming time, followed by Sphacropsis Malorum Peck. Author gives notes on the destructiveness of black rot.

\section{Ruggles, A. G., and Stakman, E. C.}

I9I I Black rot In Orchard and garden spraying. Minnesota Univ. Agr. Exp. Sta. Bul. I2 I: I5.

Symptoms of black rot given.

\section{Saccardo, P. A.}

I884 a Phoma . Ialorum (Berk.) Sacc. Syll. Fung. 3: I 52-I 53.

A technical Latin description is given. Author lists Sphaeropsis Malorum Berk. in synonymy.

I884 b Sphaeropsis Malorum Peck. Syll. Fung. 3:294.

Describes the fungus which Peck (I88I) reports and regards as new, thus giving rise to the name Sphacropsis Malorum Peck.

\section{Salmon, E. S.}

1907 Aplele leaf-spots. Gard. chron. ser. 3:42:305-306, fig. I 20-I 24. A brief discussion of varietal susceptibility and etiology of leaf spots caused by a species of Phyllosticta and one of Sphaeropsis. The author is in doubt as to whether the latter species is $S$. Malorum.

\section{Scott, W. M.}

I9o6 The contml of apple bitter-rot. U. S. Plant Inclus. Bur. Bul. 93 : I 36,1$) 1$. I -3 .

Gives (p. 27-33) results of experiments for the control of leaf spot in connection with apple scab, sooty blotch, and bitter rot.

rgo8 Apple leaf-spot. In Self-boiled lime-sulphur mixture as a promising fungicide. U. S. Plant Indus. Bur. Circ. I: I 2.

States that it appears that leaf spot may be prevented by this furgicide, but no data are cited.

I9I2 Apple leaf-spot, or fros-eye. In Spraying to control the important insects and fungous diseases affecting the fruit and foliage of the apple. Thomsen Chemical Co. (Baltimore, MId.). Circ. 4: I 4-I 5, pl. 2, fig. I.

\section{Scott, W. M., and Quaintance, A. L.}

rgo7 Leaf-spot discases. In Sinraying for apple discases and the codling moth in the Ozarks. U. S. Agr. Dept. Farmers' bul. $283:$ I $8-20$, fig. 3 .

Authors give recommendations for the control of leaf spot, which, as they state, mav be due to Sphoeropsis Malorum. 
Scott, W. M., and Rorer, J. B.

igo8 Apple leaf-spot caused by Sphacropsis Malomm. U. S. Plant Indus. Bur. Bul. I2I:45-54, pl. 3-4.

Authors discuss the common names of the leaf spot, its history, geographical occurrence, importance, symptoms, etiology, and control. Proof of the pathogenicity of Sphaeropsis Malorum on apple leaves is given, together with a study of the role of associated fungi on leaf spots.

I909 Apte blotch, a serious discase of Southem orcharls. L. S.

Plant Indus. Bur. Bul. I44: I-2S, pl, I-6.

Authors suggest (D.II) that Sphaeropsis Malorum is a factor in the killing of apple buds Further investigation is deemed desirable.

Scribner, F. L.

I89o Black-rot of the apple. Fungus discases of the wrape and other plants and their treatment, p. $8 \mathrm{I}-8_{3}$, fig. I 606.

Descriptions of the disease and of the fungus, called Macrophomo Malorum, are given.

Seaver, F. J.

I908 Color variation in some of the funci. Bul. Torrey But. Club $35: 307-3$ I 4 .

Points out that color characters are misleading and misused in the Hypocreales.

Selby, A. D.

I900 A condensed handhook of the diseases of cultivaterl plants in Ohio. Ohio Agr. Exp. Sta. Bul. I2 I: I-69, fig. I-54.

Notes (p. I4) the disease on the leaves and fruit of apple and quince.

Igro Black-rot. In A brief handlonk of the discases of cultivated plants in Ohio. Ohio Agr. Exp. Sta. Bul. 214:368-369, 436, fig. I-I05.

Notes the importance of the disease in Ohio.

I913 Disease susceptibility of apple rarieties in Ohio, Ohin Arr. Exp. Sta. Circ $133: 53-56$.

Indicates degree of susceptibility of apple varieties to black rot and canker.

Shear, C. L.

Igro Life history of Melanops Quercum (Schw.) Rehm forma Vitis Sacc. Science n. S. 31: 748.

Pure cultures of ascospores of Mclanops (uercuum (Schw.) Rehm forma I'itis Sacc. [= Botryosphaeria Berengeriana de Nat. =B. fuliginosa (M. \& N.) E. \& E.] said to produce a pyenidial form which agrees with Sphacropsis Malorum Berk, and Diplodia pseudadiplodia Fckl.

I9r3 Some observations on phytopathological problems in Europe and America. Phytopath. 3: $77-87$.

Sphaeropsis Malorum reported (p. $8 \mathrm{r}-82$ ) as doing no noticeable injury in orchards from Italy to England.

I914 Life history of Sphaeropsis Malorum Berk. Phytopath. 4 48-49. Concludes from cultural studies the ascosporic form of Sphaeropsis Malorum Berk. is Melanops Quercuum f. Vitis.

\section{Shear, C. L., and Wood, Anna K.}

I9r3 Studies of fungous parasites belonging to the senus Glomerella. U. S. Plant Indus. Bur. Bul. 252:I-rio. Illustrated.

Discuss host relationships, variability, and parasitism of Glomerella. 


\section{Sheldon, J. L.}

I905 A report on plant diseases of the State. West Virginia Univ. Agr. Exp. Sta. Bul. 96:69-99. Illustrated.

Black rot (p. 74), leaf spot (p. 74-75), and canker (p. 74) reported.

I907 The taxonomy of a leaf-spot fungus of the apple and other fruit-trees. Torreyá 7 : I $42^{2-1} 43$.

The name of the leaf spot, or frog-eye, organism is changed from Phyllosticta pirina Sacc. to Coniolhyrium pirina (Sacc.) Sheldon.

Igo8 Another leaf-spot fungus of the apple. Torreya 8:139-1+1.

Illosporium malifoliorum n. sp. is said to be concerned with the leaf spot, in a secondary manner. This fungus is described.

\section{Smith, R. I., and Stevens, F. L.}

I9I0 Leaf spot. Also, Black rot. In Insects and fungous diseases of apple and pear. North Carolina Agr. Exp. Sta. Bul. 206: $94,95,102-103$, fig. 23 .

Call the disease Sphaeropsose, and state that perhaps one, but probably several, species are responsible for leaf spot.

Stene, A. E.

I9I0 Some suggestions for Rhode Island apple growers. Rhode Island State Agr. Bd. Ann. rept. 25:93-I8I. Illustrated. Leaf spots and canker said to be general in the State (p. $152-153$ ).

\section{Stevens, F. L., and Hall, J. G.}

1907 Sphacropsis on apple twigs. In Some apple diseases. North Carolina Agr. Exp. Sta. Bul. I96: 52-53.

I909 a Notes on plant diseases occurring in North Carolina. North Carolina Agr. Exp. Sta. Ann. rept. 31:66-82, fig. I-IO.

Black rot and canker reported (p, 60). Sphaeropsis and an ascomycetous fungus found; name of latter not given. Sphaeropsis reported (p. 75) as a canker-producing fungus on pear.

I909 b Variation of fungi due to enviromment. Bot. gaz. 48: I 30 , fig. I-37. See also North Carolina Agr. Exp. Sta. Ann. rept. 32 (I908-I909):47-7 I, fig. I-37.

Authors discuss observations on the influence of environment on the characters of certain fungi.

\section{Stevens, F. L., and Sherman, F.}

Igo3 The black rot. Also, The black rot of the quince. In Insect and fungus enemies of the apple, pear, and quince, with methods of treatment. North Carolina Agr. Exp. Sta. Bul. I83:72, 82 , fig. $1-22$.

Symptoms and control measures of black rot and canker given.

Stewart, F. C.

I896 A new leaf-spot disease of apples. In Report of the Mycologist. New York (Geneva) Agr. Exp. Sta. Ann. rept. I4 (1895): 545-546.

Records Phyllosticle limilala n. sp. on apple leaves on Long Island. Technical description given. 
I904 Apple canker. In Funri and fungous diseases. Mestern Nerv York Hort. Soc. Proc. 49:53.

States that spraying for apple canker caused by Sphacropsis. Molorum is only a partial preventive; a matter not understood.

I909 Apple leaf spot. In Recent investinutions on plant diseases.

Westem New York Hort. Soc. Proc. 54: 78-79.

Believes that the leaf spot problem in New York is not completely solved. Points out that spraying often fails to control.

rgio Notes on New Iork plant discases, I. New Jork (Genera) Asr. Exp. Sta. Bul. 328:303-404, pl. I-I 8 .

Discusses (p. 312-3r3) occurrence of leaf spot in New York. Gives (p. 323-32.4) an account of a peculiar disease of the trunk of Walbridge apples and suggests that Sphacropsis Molor m may have been a factor in producing the same. Suspects (p. 377379) that the fungus also causes the failure of grafts of the pear.

Stewart, F. C., and Blodgett, F. H.

I899 A fruit-riscase survey of the IIudson Valley in r Sor). N(w Iork (Geneva) Agr. Exp. Sta. Bul. I67:273-308, pl. I-4.

Notes on the geographical occurrence of the leaf spot and canker in the Hudson Valley (p. $283,284,301-302$ ).

Stewart, F. C., and Eustace, H. J.

Igo2 Two unusual trombles of aplole foliane. New Torle (Cuntera) Agr. Exp. Sta. Bul. 220:2 I 5-233, pl. I-5.

Authors conclude that spray material caused spotting of apple foliage; suspect the parasitism of Phyllosticta; suggest that drops of rain may act as lenses and concenirate the sun's rays, overheating the tissue beneath.

Stewart, F. C., Rolfs, F. M., and Hall, F. H.

Igoo A fruit-discase strvey of western New Yorts in 10)00. New Yort: (Geneva) Agr. Exp. Sta. Bul. IgI:289-33I, pl. I-6.

Note geographical occurrence of the disease in western New York.

Stone, G. E.

I914 Lime and sulfur solutions. Massachusets Arr. Exp. Sta. Circ. 39:1 4 .

Lime and sulfur said to hold leaf spot in check, and believed to have material effect on cankers.

Stone, G. E., and Fernald, H. T.

1908 Canker. In Fungricikes, insecticides, and spraying directions. Massachusetts Agr. Exp. Sta. Bul. 123: I6.

Suggestions for canker control are given.

Stone, G. E., and Monahan, N. F.

1907 The lime and sulfur mivture as a fungicide. In Rejort of the Botanist. Massachusetts (Hatch) Agr. Exp. Sta. Ann. rept. 19: 167 .

State that observations seem to indicate that spraying with lime and sulfur succeeds to some extent in controlling canker.

Stone, G. F., and Smith, R. E.

I903 Apple-leaf spot. In Report of the Butanists. Massachusctts (Hatch) Agr. Exp. Sta. Ann. rept. 15:27, 32-34.

Frost followed by cold wet weather caused apple leaf spot. 


\section{Sturgis, W, C.}

I893 a Black-rot (Sphaeropsis Malorum Peck). In Common fungous diseases and their treatment. Connecticut (New Haven) Agr. Exp. Sta. Bul. I I 5:6-7.

Black rot of apple, quince, and pear noted.

I893 b Black rot of quinces. In Report of the Mycologist. Connecticut (New Haven) Agr. Exp. Sta. Ann. rept. I892: 43-44.

Description of black rot disease of quince fruits.

1894 Black rot (Sphaeropsis Malorum Peck). In Report of the Mycologist. Connecticut (New Haven) Agr. Exp. Sta. Ann. rept. 17: 78-79.

Reports inoculation and spore germination data. States that the wind and other agencies carry the fungus spores.

\section{Taft, L. R., and Davis, G. C.}

I895 Black rot (Sphaeropsis Malomm Berk.). In The pests of the orchard and garden. Michigan State Agr. Coll. Exp. Sta. Bul. I2 I : 2 I.

Briefly describe black rot and give suggestions for control.

\section{Taubenhaus, J. J.}

I9I2 A further study of some Glocosporiums and their relation to a sweet pea disease. Phytopath. 2: I53-I50, pl. I6, fig. I-I9.

States (p. I57) in a footnote that black rot was very prevalent in the very dry summer of I9II.

\section{Taylor, W. A.}

I9I4 Fruit discases. In Report of the Chief of the Bureau of Plant Industry. U. S. Agr. Dept. Rept. I913: 105-133.

States (p. 107) that a variety of Mclanops Quercuum has been shown to be the perfect stage of Sphaeropsis Malorum.

\section{Thümen, F. von}

I879 Fungi pomicoli, p. IoS. (Cited from Baccarini, I89o.)

\section{Waite, M. B.}

I898 a An apple canker. Western New York Hort. Soc. Proc. $43: 9-$ I I.

Briefly outlines the history and distribution of the disease, and suggests that the cause may be Schizophyllum' commune. Control measures suggested.

I898 b An apple canker. Rural New-Yorker 57: 82, fig. 32 .

Essentially the same paper as the preceding.

I906 Fungicides and their use in preventing diseases of fruits. U. S. Agr. Dept. Farmers' bul. 243: I-32, fig. I-I 7 .

Brief notes (p. Ig) on control of black rot, leaf spot, and canker.

I908 Apple leaf blight. In Diseases of orchard trees and fruits. Pennsylvania Agr. Dept. Ann. rept. 13:450-452.

Gives treatment for leaf spot.

I9ro Experiments on the apple with some new and little-known fungicides. U. S. Plant Indus. Bur. Circ. 58:I-I9.

Notes on leaf spot. 
Walker, Leva B.

I908 A new form of Sphaeropsis on apples. Nebraska Agr. Exp. Sta. Ann. rept. 21:34-44, fig. I-10.

Compares typical Sphoeropsis Malorum with a new form, the latter having larger spores, pycnidia with long necks, and no ostiole, and being more virulent in producing black rot.

\section{Wallace, Errett}

I9r3 Scab disease of apples. Cornell Univ. Agr. Exp. Sta. Bul. $335: 54 \mathrm{I}-624$. Illustrated.

Warren, G. F., and McCourt, W. E.

I905 The apple-tree canker. In An apple orchard survey of Wayne County, New York. Cornell Univ. Agr. Exp. Sta. Bul. $226: 341-345$, fig. $86-87$.

Attention is given to the economic importance of the canker and to control measures followed by the growers in this section of the country. It is said that very few mature

Twenty Ounce trees are not badly cankered, and Esopus suffers seriously.

Whetzel, H. H.

I906 The blight canker of apple and pear trees. Western New York Hort. Soc. Proc. 51:36-45.

Compares fire-blight and New York apple-tree cankers.

I907 The New York apple tree canker. In Fighting the fungi in their winter quarters. Cornell reading-course for farmers, March, I907, p. 670-67I, fig. 365 .

Gives symptoms of canker and measures for its control.

Whetzel, H. H., and Stewart, F. C.

I908 New York apple-tree canker. In Insect pests and plant diseases. IV. - The control of plant diseases Cornell Univ. Agr. Exp. Sta. Bul. 252:35), fig. I65.

Suggestions for canker control are given.

Wilcox, E. M.

1905 Black rot. Also Canker. In Diseases of the apple, cherry, peach, pear, and plum; with methods of treatment. Alabama (Auburn) Agr. Exp. Sta. Bul. I32:89-93, pl. 2, fig. 6 .

Notes on symptoms and control of black rot and canker.

Wilcox, E. M., and Stone, R. E.

I909 Black rot (Sphaeropsis Malorum). In Directions for the control of Nebraska plant diseases. Nebraska Agr. Exp. Sta. Ann. rept. 22:3I.

Give schedule for control of canker and black rot.

Wilson, G. W.

I9I3 New York canker. In Notes on three limb diseases of apple. North Carolina Agr. Exp. Sta. Ann. rept. 35:47-49, fig. I.

Brief summary of history, distribution, importance, and symptoms of the disease. Author states that the fungus may enter the bark under certain conditions, and that it does not travel in the wood. 
Wolf, F. A.

I9I0 The prevalence of certain parasitic and saprophytic fungi in orchards as determined by plate cultures. Plant world 13: $190-202$.

By use of trap cultures the author concludes that at no time during the period in which exposures were made (September to May) were viable spores of Sphaeropsis Malorum present in the atmosphere of the orchard.

I9I3 Control of apple black-rot. Phytopath. 3:288-289.

Suggests that apple mummies are a source of the inoculum. Reports that in the South lime-sulfur alone is effective against the disease; bordeaux 4-4-50 also satisfactory. A spraying schedule is given. 
